Supporting Information for:

\title{
A New Route for Installing the Isocyclic Ring on Chlorins Yielding $\mathbf{1 3}^{\mathbf{1}}$-Oxophorbines
}

Joydev K. Laha, Chinnasamy Muthiah, Masahiko Taniguchi, and Jonathan S. Lindsey

I. Nomenclature

II. Results

III. Experimental Section

1. General Methods

2. Molar Absorption Coefficients

3. Fluorescence Spectroscopy

4. Noncommercial Compounds

5. Experimental Procedures

IV. Structural Data for 13-Acetylchlorin Cu-1

V. References

VI. Spectral Data of Chlorins and Intermediates
S1

$\mathrm{S} 2-\mathrm{S} 3$

S3-S6

S3

S3

S3

S3

S3-S6

$\mathrm{S} 7-\mathrm{S} 13$

$\mathrm{S} 14$

S15-S53

\section{Nomenclature}

The nomenclature for chlorophyll-like compounds understandably relies very heavily on trivial names for derivatives and degradation products of chlorophyll compounds. The ring system for phorbine, which is recognized by IUPAC, provides a versatile parent hydrocarbon for naming chlorins containing an isocyclic ring, including those described herein. However, the IUPAC definition for phorbine adheres to a numbering system that is at odds with the widely accepted numbering system for porphyrins and chlorins. ${ }^{\text {S1 }}$ We have adopted the phorbine ring system shown as the parent hydrocarbon for naming purposes, but with use of the more reasonable chlorophyll-derived numbering system (Chart SI-1). Alternatively, the chlorin containing an isocyclic ring can be named as a derivative of a porphyrin while again maintaining the chlorophyll-derived numbering system. Thus, compound $\mathbf{2}$ is a $13^{1}$-oxophorbine, or, alternatively, a $13^{1}, 13^{2}, 17,18$-tetrahydro- $13^{1}$-oxocyclopenta $[m, n]$ porphine.

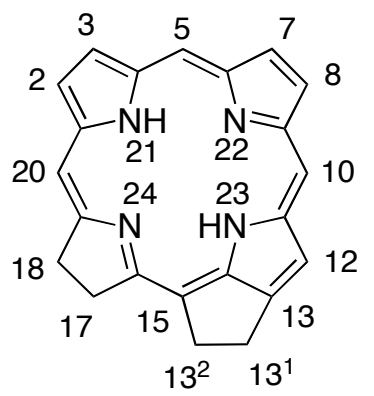

phorbine (with normal "chlorophyll" numbering)

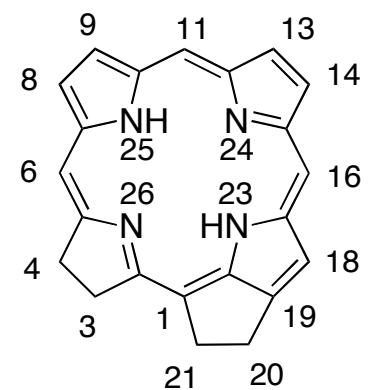

phorbine (IUPAC nomenclature)

Chart SI-1. Nomenclature. 


\section{Results}

Preparation of 5-mesityl-1-p-toluoyldipyrromethane (3). The synthesis shown in Scheme $\mathrm{S} 1$ is superior to that employed previously with use of $p$-toluoyl chloride.

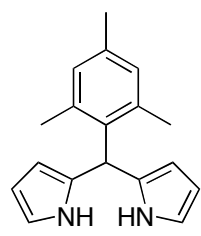

SI-1
(1) EtMgBr, THF, $-78^{\circ} \mathrm{C}$

(2)

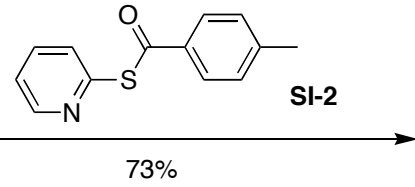

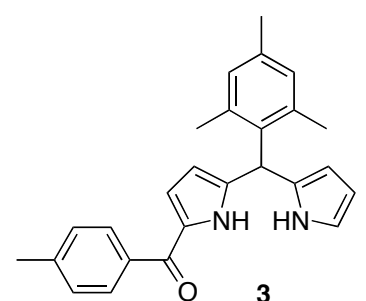

\section{Scheme S1.}

13-Acetylation. The conversion of the 13-bromochlorin to the 13 -acetylchlorin was subjected to a limited amount of optimization. Thus, heating a reaction mixture of $\mathbf{Z n - 6}$ (10 $\mathrm{mM})$, tributyl(1-ethoxyvinyl)tin ${ }^{24}(12 \mathrm{mM})$ and $10 \mathrm{~mol} \%$ of $\left(\mathrm{PPh}_{3}\right)_{2} \mathrm{PdCl}_{2}$ at $85{ }^{\circ} \mathrm{C}$ in toluene for $20 \mathrm{~h}$ followed by hydrolysis of the reaction mixture with $10 \%$ aqueous $\mathrm{HCl}$ gave 1 in $7 \%$ yield along with the recovery of free base 13 -bromo chlorin 6 ( $\sim 55 \%$ yield $)$. Changing the solvent from toluene to THF and heating the reaction mixture at $55^{\circ} \mathrm{C}$ for $20 \mathrm{~h}$ gave little improvement (17\%). A somewhat better result was observed when the mixture of Zn-6 (20 mM), tributyl(1ethoxyvinyl)tin $(40 \mathrm{mM})$ and $20 \mathrm{~mol} \%$ of $\left(\mathrm{PPh}_{3}\right)_{2} \mathrm{PdCl}_{2}$ was heated at $55{ }^{\circ} \mathrm{C}$ in $\mathrm{THF}$ for $36 \mathrm{~h}$, whereupon 1 was isolated in 29\% yield along with the recovery of free-base 13-bromochlorin 6 $(\sim 22 \%)$. Substantially higher yields were obtained upon use of the free base chlorin 6 rather than the zinc chelate $\mathbf{Z n - 6}$ as described in the main text.

Spectral Comparison. The absorption spectrum of free base $13^{1}$-oxophorbine 2 is quite similar to that of pheophorbide $a$. The overlaid spectra are shown in Figure SI-1. Note that the $\mathrm{I}_{\mathrm{B}} / \mathrm{I}_{\mathrm{Qy}}$ ratio of $13^{1}$-oxophorbine 2 is 2.0 , that of pheophorbide $a$ is 2.1 , whereas that of chlorophyll $a$ is 1.3 .

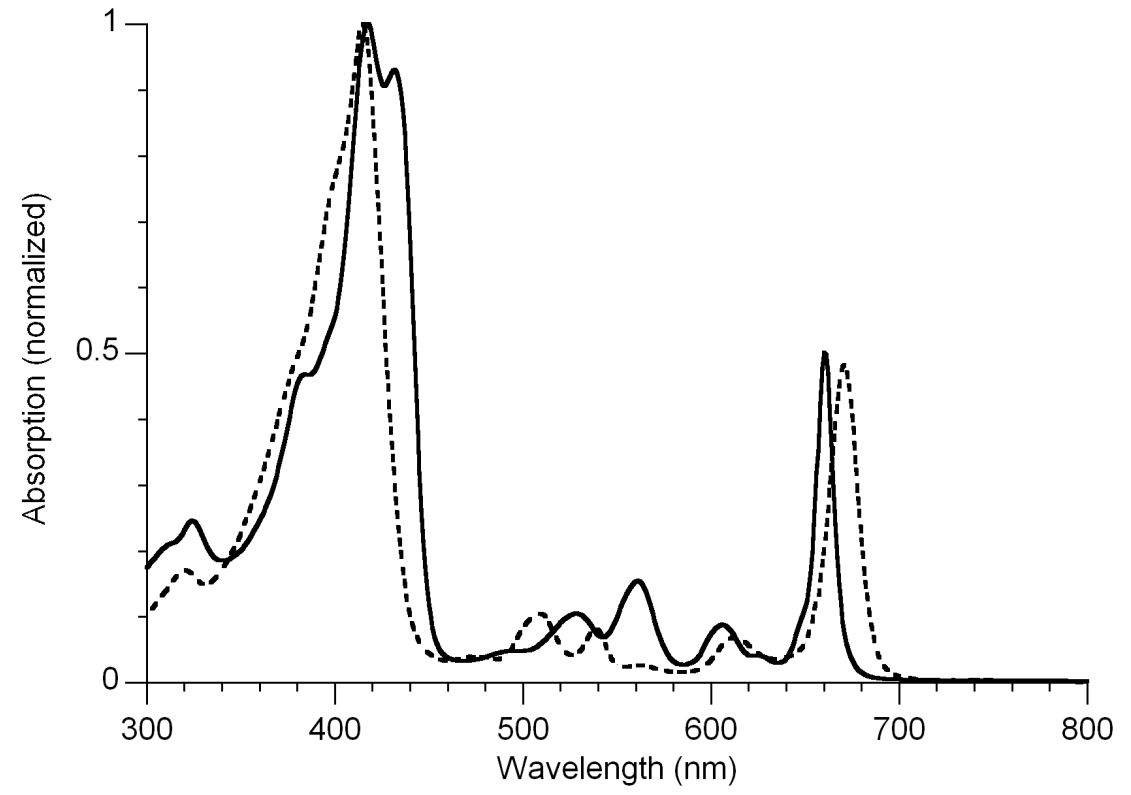

Figure SI-1. Absorption spectra of 2 (solid line) and pheophorbide $a$ (dotted line) in toluene at room temperature. 
8,9-Dibromodipyrromethane Stability Study. A solution of 4 (3.0 mg, $6 \mu \mathrm{mol})$ was dissolved in a solvent $(0.6 \mathrm{~mL})$ at room temperature. After standing for $2 \mathrm{~h}$, the sample was concentrated to dryness under reduced pressure at room temperature. The residue was dissolved in an NMR solvent $\left(\mathrm{CDCl}_{3}\right.$ or $\left.\mathrm{THF}-d_{8}\right)$ and the ${ }^{1} \mathrm{H}$ NMR spectrum was recorded. The samples in the NMR solvent were examined periodically over a prolonged period. The purified compound 4 decomposed almost completely within 8-10 h in chlorinated hydrocarbon solvents even at 0 ${ }^{\circ} \mathrm{C}$, but was stable as a powdered solid upon storage at $-20{ }^{\circ} \mathrm{C}$ for 20 days. Compound 4 decomposed partially during lengthy NMR experiments (regardless of solvent such as $\mathrm{CDCl}_{3}$, $\mathrm{C}_{6} \mathrm{D}_{6}$ or $\mathrm{THF}-d_{8}$ ) or attempted crystallization.

\section{Experimental Section}

1. General. ${ }^{1} \mathrm{H}$ NMR spectra $(400 \mathrm{MHz})$ and ${ }^{13} \mathrm{C}$ NMR spectra $(75 \mathrm{MHz})$ were collected at room temperature in $\mathrm{CDCl}_{3}$. Absorption spectra were obtained in toluene at room temperature. Chlorins were analyzed by laser desorption mass spectrometry (LD-MS) in the absence of a matrix. ${ }^{\text {S2 }}$ Fast atom bombardment mass spectrometry (FAB-MS) data are reported for the molecule ion or protonated molecule ion. Melting points are uncorrected. All commercially available materials were used as received. All palladium-coupling reactions were carried out using standard Schlenk-line techniques. Distilled solvents were used for workup and column chromatography. After loading the crude chlorin product onto a column, hexanes (400 $\mathrm{mL}$ ) was used to remove any hydrophobic impurities prior to eluting with a more polar solvent or solvent mixture.

The chlorin-forming reaction was performed during a single day starting from the preparation of the 8,9-dibromo-1-acyldipyrromethane. The condensation of an Eastern half and the Western half was carried out at room temperature under argon. An ice-cold solution of the crude product in $\mathrm{CH}_{3} \mathrm{CN}$ was treated with 2,2,6,6-tetramethylpiperidine followed by $\mathrm{Zn}(\mathrm{OAc})_{2}$ and AgOTf. The reaction mixture was stirred at room temperature for 10-15 min before heating to gentle reflux.

2. Molar Absorption Coefficients. The molar absorption coefficients were determined as described in the Supporting Information of Reference 20.

3. Fluorescence Spectroscopy. The fluorescence spectra and fluorescence quantum yields reported herein were collected in toluene at room temperature. Measurements of fluorescence quantum yield $\left(\Phi_{\mathrm{f}}\right)$ were carried out using chlorophyll a $\left(\Phi_{\mathrm{f}}=0.322\right.$, in toluene $)$ as a standard. $^{20}$

4. Noncommercial Compounds. Compounds SI-1, ${ }^{21}$ SI-2, ${ }^{22} \mathbf{3}^{22}$ and $\mathbf{5}^{19,23}$ were prepared following literature procedures.

\section{Experimental Procedures}

13-Acetylation (from Zn-6) including Demetalation, Coupling, and Hydrolysis: 13Acetyl-17,18-dihydro-10-mesityl-18,18-dimethyl-5-p-tolylporphyrin (1). A solution of Zn-6 (200 mg, $0.289 \mathrm{mmol})$ in $\mathrm{CH}_{2} \mathrm{Cl}_{2}(8 \mathrm{~mL})$ was treated dropwise with TFA $(0.668 \mathrm{~mL}, 8.67$ mmol). The solution was stirred at room temperature for $3 \mathrm{~h} . \mathrm{CH}_{2} \mathrm{Cl}_{2}$ was added and the organic layer was washed with saturated aqueous $\mathrm{NaHCO}_{3}$, water, and brine. The organic layer was separated, dried $\left(\mathrm{Na}_{2} \mathrm{SO}_{4}\right)$ and concentrated. The resulting crude solid was used in the next step. Following a procedure for Stille coupling, ${ }^{24}$ a mixture composed of the crude sample of $\mathbf{6}$, tributyl(1-ethoxyvinyl)tin $(390 \mu \mathrm{L}, 1.16 \mathrm{mmol})$ and $\left(\mathrm{PPh}_{3}\right)_{2} \mathrm{PdCl}_{2}(30.4 \mathrm{mg}, 0.0433 \mathrm{mmol})$ was refluxed in THF $(15 \mathrm{~mL})$ for $18 \mathrm{~h}$ in a Schlenk line. The reaction mixture was treated with $10 \%$ aqueous $\mathrm{HCl}(11 \mathrm{~mL})$ at room temperature for $2 \mathrm{~h} . \mathrm{CH}_{2} \mathrm{Cl}_{2}$ was added and the organic layer was 
separated. The organic layer was washed (saturated aqueous $\mathrm{NaHCO}_{3}$, water, and brine), dried $\left(\mathrm{Na}_{2} \mathrm{SO}_{4}\right)$, and concentrated. The residue was chromatographed [silica, hexanes/ $\mathrm{CH}_{2} \mathrm{Cl}_{2}(1: 1)$ ], affording a purple solid $(117 \mathrm{mg}, 68 \%)$. The characterization data ( ${ }^{1} \mathrm{H}$ NMR, LD-MS, FAB-MS, $\mathrm{UV}-\mathrm{Vis}$ ) were consistent with those for the product obtained as described in the main text.

Zn(II)-13-Acetyl-17,18-dihydro-10-mesityl-18,18-dimethyl-5-p-tolylporphyrin (Zn1). A solution of $1(20 \mathrm{mg}, 0.034 \mathrm{mmol})$ in $\mathrm{CHCl}_{3}(2.8 \mathrm{~mL})$ was treated with a solution of $\mathrm{Zn}(\mathrm{OAc})_{2} \cdot 2 \mathrm{H}_{2} \mathrm{O}(75 \mathrm{mg}, 0.34 \mathrm{mmol})$ in methanol $(0.7 \mathrm{~mL})$. The reaction mixture was stirred at room temperature for $16 \mathrm{~h}$. $\mathrm{CH}_{2} \mathrm{Cl}_{2}$ was added and the reaction mixture was washed with water and brine. The organic layer was dried $\left(\mathrm{Na}_{2} \mathrm{SO}_{4}\right)$. The crude mixture was concentrated and chromatographed (silica, $\mathrm{CH}_{2} \mathrm{Cl}_{2}$ ), affording a green solid $(18 \mathrm{mg}, 81 \%)$ : ${ }^{1} \mathrm{H}$ NMR $\delta 1.84(\mathrm{~s}$, $6 \mathrm{H}), 1.98(\mathrm{~s}, 6 \mathrm{H}), 2.58(\mathrm{~s}, 3 \mathrm{H}), 2.64(\mathrm{~s}, 3 \mathrm{H}), 2.87(\mathrm{~s}, 3 \mathrm{H}), 4.46(\mathrm{~s}, 2 \mathrm{H}), 7.20(\mathrm{~s}, 2 \mathrm{H}), 7.46(\mathrm{~d}, J=$ $8.2 \mathrm{~Hz}, 2 \mathrm{H}), 7.89(\mathrm{~d}, J=8.2 \mathrm{~Hz}, 2 \mathrm{H}), 8.16(\mathrm{~d}, J=4.4 \mathrm{~Hz}, 1 \mathrm{H}), 8.24(\mathrm{~d}, J=4.4 \mathrm{~Hz}, 1 \mathrm{H}), 8.44$ (s, $1 \mathrm{H}), 8.57(\mathrm{~d}, J=4.4 \mathrm{~Hz}, 1 \mathrm{H}), 8.58(\mathrm{~d}, J=4.4 \mathrm{~Hz}, 1 \mathrm{H}), 8.81(\mathrm{~s}, 1 \mathrm{H}), 9.64(\mathrm{~s}, 1 \mathrm{H})$; LD-MS obsd 652.1; FAB-MS obsd 652.2165, calcd 652.2181 $\left(\mathrm{C}_{40} \mathrm{H}_{36} \mathrm{~N}_{4} \mathrm{OZn}\right) ; \lambda_{\text {abs }} 424(\log \varepsilon=5.30), 635$ (4.85) nm, $\lambda_{\mathrm{em}} 639 \mathrm{~nm}\left(\Phi_{\mathrm{f}}=0.25\right)$.

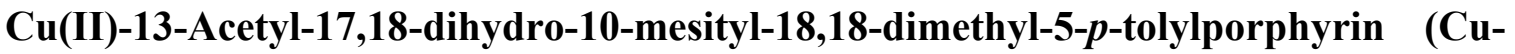
1). A solution of $1(19 \mathrm{mg}, 0.032 \mathrm{mmol})$ in $\mathrm{CHCl}_{3}(3.2 \mathrm{~mL})$ was treated with a solution of $\mathrm{Cu}(\mathrm{OAc})_{2} \cdot \mathrm{H}_{2} \mathrm{O}(65 \mathrm{mg}, 0.32 \mathrm{mmol})$ in methanol $(0.8 \mathrm{~mL})$ at room temperature for $16 \mathrm{~h}$. The reaction mixture was washed with water and brine. The organic layer was dried $\left(\mathrm{Na}_{2} \mathrm{SO}_{4}\right)$, concentrated and chromatographed [silica, hexanes $/ \mathrm{CH}_{2} \mathrm{Cl}_{2}(1: 1)$ ], affording a purple solid (17 mg, 81\%): LD-MS obsd 651.7; FAB-MS obsd 651.2202, calcd $651.2185\left(\mathrm{C}_{40} \mathrm{H}_{36} \mathrm{~N}_{4} \mathrm{OCu}\right) ; \lambda_{\text {abs }}$ 420, $631(\log \varepsilon=4.69) \mathrm{nm}$.

Streamlined Procedure for 15-Bromination and Installation of the Isocyclic Ring: 10-Mesityl-18,18-dimethyl-13 ${ }^{1}$-oxo-5-p-tolylphorbine (2). Following a reported procedure, ${ }^{26}$ a solution of 1 (18 mg, $0.030 \mathrm{mmol})$ in THF $(15 \mathrm{~mL})$ was treated with NBS (5.5 mg, $0.030 \mathrm{mmol})$ at room temperature for $1 \mathrm{~h}$. $\mathrm{CH}_{2} \mathrm{Cl}_{2}$ was added. The mixture was washed with aqueous $\mathrm{NaHCO}_{3}$. The organic layer was dried $\left(\mathrm{Na}_{2} \mathrm{SO}_{4}\right)$ and concentrated. The crude mixture was used in the next step. Following a procedure for $\alpha$-arylation of aliphatic ketones, ${ }^{25}$ a mixture of the crude solid, $\mathrm{Cs}_{2} \mathrm{CO}_{3}(50 \mathrm{mg}, 0.15 \mathrm{mmol})$, and $\left(\mathrm{PPh}_{3}\right)_{2} \mathrm{PdCl}_{2}(4.2 \mathrm{mg}, 6.0 \mu \mathrm{mol})$ was refluxed in toluene $(3 \mathrm{~mL})$ for $20 \mathrm{~h}$ in a Schlenk line. $\mathrm{CH}_{2} \mathrm{Cl}_{2}$ was added. The reaction mixture was washed with water and brine. The organic layer was dried $\left(\mathrm{Na}_{2} \mathrm{SO}_{4}\right)$, concentrated and chromatographed [silica, hexanes $/ \mathrm{CH}_{2} \mathrm{Cl}_{2}$ (1:3)], affording a purple solid (8.0 $\left.\mathrm{mg}, 44 \%\right)$. The characterization data ( ${ }^{1} \mathrm{H}$ NMR, LD-MS, FAB-MS, UV-Vis) were consistent with those for the product obtained as described in the main text.

5-Mesityl-1-(4-methylbenzoyl)dipyrromethane (3). Following a reported procedure, ${ }^{22}$ a solution of EtMgBr $(30.0 \mathrm{~mL}, 30.0 \mathrm{mmol}, 1.0 \mathrm{M}$ solution in THF) was added dropwise to a solution of SI-1 (2.64 g, $10.0 \mathrm{mmol})$ in dry THF $(50 \mathrm{~mL})$ over a $5 \mathrm{~min}$ period. The solution was stirred at room temperature for $30 \mathrm{~min}$. The solution was cooled to $-78^{\circ} \mathrm{C}$ and then a solution of SI-2 $(2.75 \mathrm{~g}, 12.0 \mathrm{mmol})$ in dry THF $(20 \mathrm{~mL})$ was added dropwise. The mixture was stirred for $3 \mathrm{~h}$ at $-78{ }^{\circ} \mathrm{C}$. Saturated aqueous $\mathrm{NH}_{4} \mathrm{Cl}$ was added. The mixture was extracted with $\mathrm{CH}_{2} \mathrm{Cl}_{2}$. The organic phase was dried $\left(\mathrm{Na}_{2} \mathrm{SO}_{4}\right)$, concentrated and chromatographed [silica, hexanes $/ \mathrm{CH}_{2} \mathrm{Cl}_{2} /$ ethyl acetate $(7: 2: 1)$ ], affording a pale yellow solid $(2.80 \mathrm{~g}, 73 \%)$ : $\mathrm{mp} 74-75^{\circ} \mathrm{C}$ [lit. ${ }^{18} 75-77{ }^{\circ} \mathrm{C}$ ]; ${ }^{1} \mathrm{H}$ NMR $\delta 2.10(\mathrm{~s}, 6 \mathrm{H}), 2.30(\mathrm{~s}, 3 \mathrm{H}), 2.43(\mathrm{~s}, 3 \mathrm{H}), 5.96(\mathrm{~s}, 1 \mathrm{H}), 6.12(\mathrm{~m}, 2 \mathrm{H})$, $6.22(\mathrm{~m}, 1 \mathrm{H}), 6.68(\mathrm{~s}, 1 \mathrm{H}), 6.83(\mathrm{~m}, 1 \mathrm{H}), 6.90(\mathrm{~s}, 2 \mathrm{H}), 7.26(\mathrm{~d}, J=7.5 \mathrm{~Hz}, 2 \mathrm{H}), 7.77(\mathrm{~d}, J=7.5$ $\mathrm{Hz}, 2 \mathrm{H}), 7.85$ (br, 1H), 9.23 (br, 1H); ${ }^{13} \mathrm{C}$ NMR $\delta$ 20.6, 20.7, 21.5, 38.6, 107.1, 108.9, 109.9, $116.8,120.1$, 128.9, 129.1, 129.9, 130.5, 133.1, 135.7, 137.2, 137.4, 140.4, 142.1, 183.9; Anal. 
Calcd for $\mathrm{C}_{26} \mathrm{H}_{26} \mathrm{~N}_{2} \mathrm{O}$ : C, 81.64; H, 6.85; N, 7.32. Found: C, 81.49; H, 7.01; N, 7.01. Note: Some amount $(\sim 10 \%)$ of the starting 5-mesityldipyrromethane was recovered in this reaction.

Dibromination: 8,9-Dibromo-5-mesityl-1-(4-methylbenzoyl)dipyrromethane (4). Following a procedure for 8,9-dibromination of 1 -acyldipyrromethanes, ${ }^{20}$ a solution of 3 (573 $\mathrm{mg}, 1.50 \mathrm{mmol})$ in dry THF $(15 \mathrm{~mL})$ at $-78^{\circ} \mathrm{C}$ under argon was treated portionwise with NBS $(587 \mathrm{mg}, 3.30 \mathrm{mmol})$. The reaction mixture was stirred for $1 \mathrm{~h}$ at $-78{ }^{\circ} \mathrm{C}$. Hexanes was added to the reaction mixture at $-20{ }^{\circ} \mathrm{C}$. The reaction mixture was then allowed to warm to $0{ }^{\circ} \mathrm{C}$. The organic layer was washed with ice-cold water, dried $\left(\mathrm{K}_{2} \mathrm{CO}_{3}\right)$ and concentrated without heating in a water-bath at ambient temperature. The resulting brown solid was dissolved in a minimum amount of THF and placed on top of a silica column for chromatography. Elution with hexanes/ $\mathrm{CH}_{2} \mathrm{Cl}_{2} /$ ethyl acetate $(7: 2: 1)$ afforded a fraction which upon solvent evaporation yielded a yellow solid $(0.465 \mathrm{~g}, 57 \%)$ : mp $120-122{ }^{\circ} \mathrm{C}(\mathrm{dec}) ;{ }^{1} \mathrm{H}$ NMR $\left(\mathrm{THF}-d_{8}\right) \delta 2.08(\mathrm{~s}, 6 \mathrm{H}), 2.30(\mathrm{~s}$, $3 \mathrm{H}), 2.42(\mathrm{~s}, 3 \mathrm{H}), 5.81(\mathrm{~s}, 1 \mathrm{H}), 6.05(\mathrm{~d}, J=3.3 \mathrm{~Hz}, 1 \mathrm{H}), 6.12(\mathrm{dd}, J=4.2,3.3 \mathrm{~Hz}, 1 \mathrm{H}), 6.80(\mathrm{dd}$, $J=4.2,3.3 \mathrm{~Hz}, 1 \mathrm{H}), 6.90(\mathrm{~s}, 2 \mathrm{H}), 7.26(\mathrm{~d}, J=8.1 \mathrm{~Hz}, 2 \mathrm{H}), 7.74(\mathrm{~d}, J=8.1 \mathrm{~Hz}, 2 \mathrm{H}), 8.07$ (br, 1H), $9.10(\mathrm{br}, 1 \mathrm{H}) ;{ }^{13} \mathrm{C}$ NMR $\left(\mathrm{THF}-d_{8}\right) \delta 21.0,21.2,21.6,40.4,98.3,99.3,110.9,111.7,119.2$, 129.6, 129.9, 131.1, 132.3, 134.9, 135.1, 137.1, 137.6, 138.4, 140.4, 142.6, 183.8; FAB-MS obsd 538.0240, calcd 538.0255 $\left(\mathrm{C}_{26} \mathrm{H}_{24} \mathrm{Br}_{2} \mathrm{~N}_{2} \mathrm{O}\right)$.

Notes: (1) The use of ethyl acetate or any chlorinated solvent should be avoided in extraction procedures. All of the workup operations including solvent removal should be done without heating, and preferably under chilled conditions.

(2) The chromatography solvent mixture (hexanes $/ \mathrm{CH}_{2} \mathrm{Cl}_{2} /$ ethyl acetate) was stored over anhydrous $\mathrm{K}_{2} \mathrm{CO}_{3}$ prior to use.

(3) The isolated pure 4 is somewhat labile. Careful handling of the solution of compound 4 is required. Compound $\mathbf{4}$ decomposes almost completely in solution (such as a chlorinated hydrocarbon solvent) within $8-10 \mathrm{~h}$ at $0{ }^{\circ} \mathrm{C}$. Compound 4 in powdered solid form can be stored at $-20{ }^{\circ} \mathrm{C}$ for 30 days without decomposition. Compound 4 in $\mathrm{CDCl}_{3}$ was stable for $2 \mathrm{~h}$ and decomposed completely after $5 \mathrm{~h}$. Compound 4 in THF- $d_{8}$ was stable for $10 \mathrm{~h}$ and significant amount of decomposition was observed after $24 \mathrm{~h}$. Attempted crystallization of compound 4 was unsuccessful.

Chlorin Formation at Small Scale: Zn(II)-13-Bromo-17,18-dihydro-10-mesityl18,18-dimethyl-5-p-tolylporphyrin (Zn-6). Following the standard procedure ${ }^{19}$ at modest scale, a solution of 4 (465 mg, $0.860 \mathrm{mmol})$ in THF/MeOH $(4: 1,45 \mathrm{~mL})$ was treated portionwise with a sample of $\mathrm{NaBH}_{4}(325 \mathrm{mg}, 8.60 \mathrm{mmol})$ at $0{ }^{\circ} \mathrm{C}$ and the reaction mixture was stirred at room temperature for $3 \mathrm{~h}$ under argon. The completion of the reduction can be monitored by TLC analysis (hexanes/ethyl acetate $=3: 1$ ). Saturated aqueous $\mathrm{NH}_{4} \mathrm{Cl}$ was added at $0{ }^{\circ} \mathrm{C}$. The mixture was extracted with ethyl acetate (ice-cold). The combined organic extracts were dried $\left(\mathrm{K}_{2} \mathrm{CO}_{3}\right)$ and concentrated under reduced pressure without heating. The crude mixture was placed on a vacuum line for a few minutes to remove residual solvent, affording a yellow foamlike solid. The resulting solid was dissolved in anhydrous $\mathrm{CH}_{3} \mathrm{CN}(8.6 \mathrm{~mL})$ at $0{ }^{\circ} \mathrm{C}$. Western half 5 (164 mg, $0.860 \mathrm{mmol})$ was added followed by dropwise addition of TFA $(64 \mu \mathrm{L}, 0.83$ mmol). The reaction mixture was stirred at room temperature under argon for $30 \mathrm{~min}$. The reaction mixture was diluted with $\mathrm{CH}_{3} \mathrm{CN}(77 \mathrm{~mL})$ at $0{ }^{\circ} \mathrm{C}$. 2,2,6,6-Tetramethylpiperidine (1.52 $\mathrm{mL}, 9.00 \mathrm{mmol}$ ) was added dropwise over $5 \mathrm{~min}$ at $0{ }^{\circ} \mathrm{C}$, and the reaction mixture was stirred at $0{ }^{\circ} \mathrm{C}$ for 5-10 min. $\mathrm{Zn}(\mathrm{OAc})_{2}(1.10 \mathrm{~g}, 6.00 \mathrm{mmol})$ was added followed by AgOTf (464 mg, 1.80 $\mathrm{mmol})$. The resulting suspension was refluxed for $18 \mathrm{~h}$ exposed to air. The crude mixture was concentrated and chromatographed [silica, hexanes $/ \mathrm{CH}_{2} \mathrm{Cl}_{2}(2: 1)$ ], affording a green solid (83 mg, 14\%): ${ }^{1} \mathrm{H}$ NMR $\delta 1.86$ (s, 6H), 2.02 (s, 6H), 2.58 (s, 3H), 2.66 (s, 3H), 4.53 (s, 2H), 7.21 (s, 
2H), $7.48(\mathrm{~d}, J=8.1 \mathrm{~Hz}, 2 \mathrm{H}), 7.94(\mathrm{~d}, J=8.1 \mathrm{~Hz}, 2 \mathrm{H}), 8.22(\mathrm{~d}, J=4.8 \mathrm{~Hz}, 1 \mathrm{H}), 8.35$ (d, $J=4.4$ $\mathrm{Hz}, 1 \mathrm{H}), 8.50(\mathrm{~s}, 1 \mathrm{H}), 8.56(\mathrm{~s}, 1 \mathrm{H}), 8.64(\mathrm{~d}, J=4.8 \mathrm{~Hz}, 1 \mathrm{H}), 8.66$ (d, $J=4.4 \mathrm{~Hz}, 1 \mathrm{H}), 8.79$ (s, 1H); LD-MS obsd 689.8; FAB-MS obsd 688.1178, calcd $688.1180\left(\mathrm{C}_{38} \mathrm{H}_{33} \mathrm{BrN}_{4} \mathrm{Zn}\right) ; \lambda_{\text {abs }} 414$, $617 \mathrm{~nm}$.

Notes: (1) The completion of reduction can be monitored by TLC analysis [silica, hexanes/ethyl acetate, (3:1)]. On some occasions, reduction of 4 using 10 equiv of $\mathrm{NaBH}_{4}$ is not complete in $3 \mathrm{~h}$. In that case, it is necessary to add more (5 equiv) $\mathrm{NaBH}_{4}$ in the reaction mixture or stir the reaction mixture for a prolonged period. The use of chlorinated solvents should be avoided during workup. All of the operations including solvent removal should be done without heating and preferably under chilled conditions. The resulting dipyrromethane-1-carbinol changes color from yellow to reddish during removal of the residual solvent.

(2) During the tetrahydrobilene $a$ formation, all operations (such as addition of Western half or TFA) should be done as quickly as possible. After $30 \mathrm{~min}$, the color of the reaction mixture changed from yellow to reddish brown.

Chlorin Formation at Medium Scale: Zn(II)-13-Bromo-17,18-dihydro-10-mesityl18,18-dimethyl-5-p-tolylporphyrin (Zn-6). All the points noted above for compound $\mathbf{Z n - 6}$ are equally applicable here, where the synthesis was carried out at larger scale and with a greater relative quantity of the reagents in the metal-mediated oxidative cyclization. A solution of $\mathbf{4}$ (755 mg, $1.40 \mathrm{mmol})$ in $\mathrm{THF} / \mathrm{MeOH}(4: 1,70 \mathrm{~mL})$ was treated portionwise with a sample of $\mathrm{NaBH}_{4}(530 \mathrm{mg}, 14.0 \mathrm{mmol})$ at $0{ }^{\circ} \mathrm{C}$ and the reaction mixture was stirred at room temperature for $3 \mathrm{~h}$ under argon. Saturated aqueous $\mathrm{NH}_{4} \mathrm{Cl}$ was added at $0{ }^{\circ} \mathrm{C}$. The mixture was extracted with ethyl acetate (ice-cold). The combined organic extracts were dried $\left(\mathrm{K}_{2} \mathrm{CO}_{3}\right)$ and concentrated under reduced pressure without heating. The crude mixture was placed on a vacuum line for a few minutes to remove residual solvent, affording a yellow foam-like solid. The resulting solid was dissolved in anhydrous $\mathrm{CH}_{3} \mathrm{CN}(14 \mathrm{~mL})$ at $0{ }^{\circ} \mathrm{C}$. Western half 5 (267 $\mathrm{mg}, 1.40 \mathrm{mmol})$ was added followed by dropwise addition of TFA $(108 \mu \mathrm{L}, 1.40 \mathrm{mmol})$. The reaction mixture was stirred at room temperature under argon for $30 \mathrm{~min}$. The reaction mixture

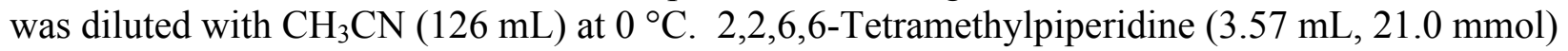
was added and the reaction mixture was stirred at $0{ }^{\circ} \mathrm{C}$ for $5-10 \mathrm{~min}$. $\mathrm{Zn}(\mathrm{OAc})_{2}(2.57 \mathrm{~g}, 14.0$ mmol) was added followed by AgOTf $(1.08 \mathrm{~g}, 4.20 \mathrm{mmol})$. The resulting suspension was refluxed for $18 \mathrm{~h}$ exposed to air. The crude mixture was concentrated and chromatographed [silica, hexanes $/ \mathrm{CH}_{2} \mathrm{Cl}_{2}(2: 1)$ ], affording a green solid $(200 \mathrm{mg}, 20 \%)$. The characterization data ( ${ }^{1} \mathrm{H}$ NMR, LD-MS, FAB-MS, UV-Vis) were consistent with those for the product obtained as described above.

Chlorin Demetalation: 13-Bromo-17,18-dihydro-10-mesityl-18,18-dimethyl-5-ptolylporphyrin (6). A solution of $\mathbf{Z n - 6}(41.2 \mathrm{mg}, 0.0596 \mathrm{mmol})$ in $\mathrm{CH}_{2} \mathrm{Cl}_{2}(1.6 \mathrm{~mL})$ was treated dropwise with TFA $(138 \mu \mathrm{L}, 1.78 \mathrm{mmol})$ over a 3 min period. The solution was stirred at room temperature for $2 \mathrm{~h}$. $\mathrm{CH}_{2} \mathrm{Cl}_{2}$ was added and the organic layer was washed (saturated aqueous $\mathrm{NaHCO}_{3}$, water, and brine) and then dried $\left(\mathrm{Na}_{2} \mathrm{SO}_{4}\right)$. The crude mixture was concentrated and chromatographed [silica, hexanes then hexanes $/ \mathrm{CH}_{2} \mathrm{Cl}_{2}(2: 1)$ ], affording a purple solid (32.8 $\mathrm{mg}$, 88\%): ${ }^{1} \mathrm{H}$ NMR $\delta-1.70(\mathrm{br}, 2 \mathrm{H}), 1.85$ (s, 6H), 2.05 (s, 6H), 2.60 (s, 3H), 2.67 (s, 3H), 4.62 (s, $2 \mathrm{H}), 7.23(\mathrm{~s}, 2 \mathrm{H}), 7.50(\mathrm{~d}, J=8.1 \mathrm{~Hz}, 2 \mathrm{H}), 7.99(\mathrm{~d}, J=8.1 \mathrm{~Hz}, 2 \mathrm{H}), 8.30(\mathrm{~d}, J=4.8 \mathrm{~Hz}, 1 \mathrm{H})$, $8.43(\mathrm{~d}, J=4.4 \mathrm{~Hz}, 1 \mathrm{H}), 8.60(\mathrm{~s}, 1 \mathrm{H}), 8.76(\mathrm{~d}, J=4.8 \mathrm{~Hz}, 1 \mathrm{H}) ; 8.80(\mathrm{~d}, J=4.4 \mathrm{~Hz}, 1 \mathrm{H}), 8.84(\mathrm{~s}$, 1H), 9.03 (s, 1H); LD-MS obsd 626.4; FAB-MS obsd 626.2053, calcd $626.2045\left(\mathrm{C}_{38} \mathrm{H}_{35} \mathrm{~N}_{4} \mathrm{Br}\right)$; $\lambda_{\text {abs }} 419,648 \mathrm{~nm}$. 


\section{X-ray Structural Data for Cu-1}

A single-crystal X-ray structure of Cu-1 was determined (Figures SI-2 and SI-3). The crystal structure of $\mathbf{C u - 1}$ shows the near coplanarity of the acetyl group with the chlorin macrocycle in the solid state. It has been shown that the acetyl group of 13-acetylporphyrins in an unhindered $\beta$-pyrrolic position can adopt a planar conformation and thus conjugate with the $\pi$-electron of the macrocycle. ${ }^{\mathrm{S} 3}$ An additional interesting feature of the X-ray structure is that the carbonyl group is pointed toward the 15-position. By contrast, the carbonyl group in the oxophorbines (and in chlorophylls) is pointed toward the 12-position and away from the 15position. For structures of other chlorins, see the database prepared by Senge. ${ }^{\mathrm{S} 4}$
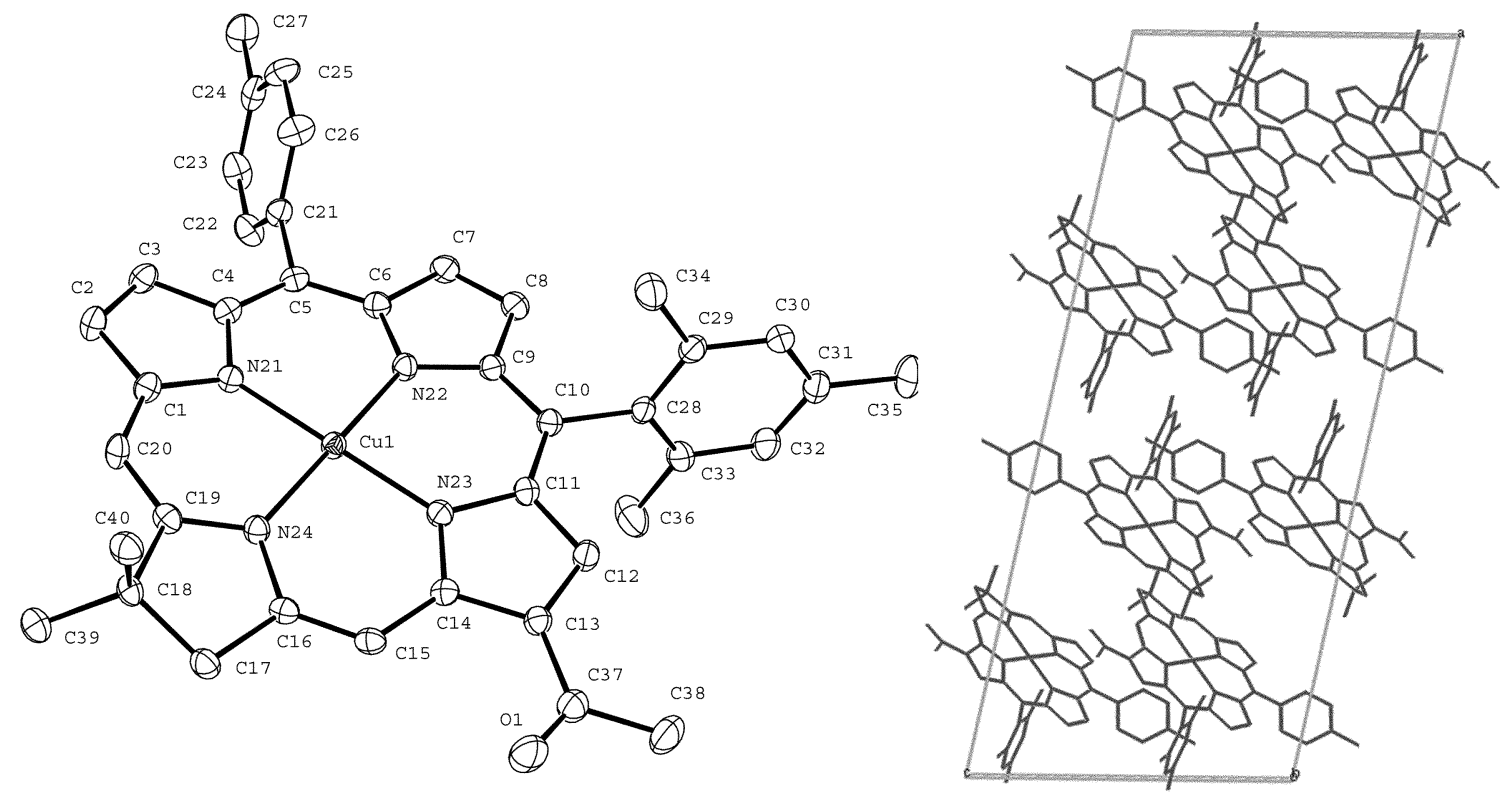

Figure SI-2. ORTEP drawing from the X-ray analysis of Cu-1 with 50\% probability ellipsoids (left panel) and packing pattern in the unit cell (right panel). Hydrogens are omitted for clarity.
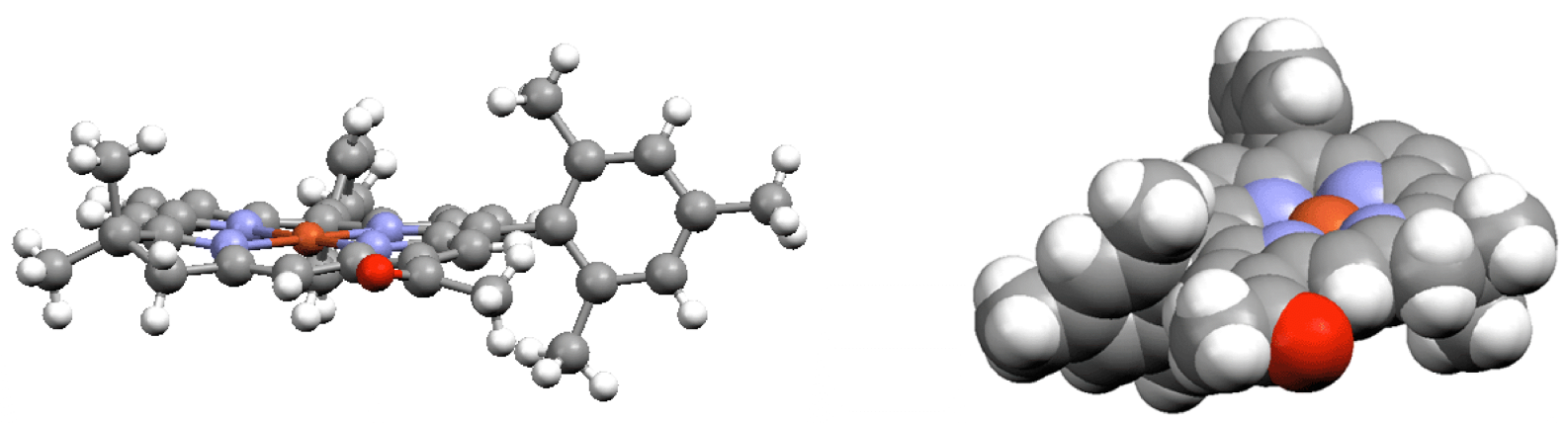

Figure SI-3. Cu-1 in ball and stick model (left panel) and CPK model (right panel).

Sample. A sample of $\mathbf{C u - 1}$ in $\mathrm{CH}_{2} \mathrm{Cl}_{2}$ at room temperature was crystallized by slow infusion of cyclohexane.

Data Collection. The sample (Cu-1) was mounted on a 20 micron nylon loop with a small amount of immersion oil. All X-ray measurements were made on a Bruker-Nonius X8 Apex 2 CCD diffractometer at $110 \mathrm{~K}$. The temperature of the sample was controlled with a cold 
stream of nitrogen. The unit cell dimensions were determined from a symmetry constrained fit of 7257 reflections with $4.53^{\circ}<2 \theta<49.95^{\circ}$. The data collection strategy was a number of $\omega$ and $\varphi$ scans which collected data up to $59.9^{\circ}(2 \theta)$. The frame integration was performed using SAINT+. ${ }^{\text {S5 }}$ The resulting raw data was scaled and absorption corrected using a multi-scan averaging of symmetry equivalent data using SADABS. ${ }^{\mathrm{S} 6}$

Structure Solution and Refinement. The structure was solved by direct methods using SIR92. ${ }^{\text {S7 }}$ All non-hydrogen atoms were obtained from the initial E-map. The hydrogen atoms were introduced at idealized positions and were allowed to ride on the parent carbon atom. All non-hydrogen atoms were allowed to refine anisotropically. The structural model was fit to the data using full matrix least-squares based on F. The calculated structure factors included corrections for anomalous dispersion from the usual tabulation. A secondary extinction correction was not included in the final refinements because attempts to refine the extinction led to a physically meaningless parameter. The structure was refined, final tables and graphic plots were produced using the NRCVAX crystallographic program suite. ${ }^{\mathrm{S} 8}$ Additional information and other relevant literature references can be found in the REPORT.OUT file and the reference section of the Facility's Web page (http://www.xray.ncsu.edu). 
Table SI-1. Crystal data and structure refinement for the $\mathbf{C u - 1}$ sample.

\begin{tabular}{|c|c|c|}
\hline Empirical formula & $\mathrm{C}_{40} \mathrm{H}_{36} \mathrm{~N}_{4} \mathrm{CuO}$ & \\
\hline Formula weight & 652.29 & \\
\hline Temperature & $110 \mathrm{~K}$ & \\
\hline Wavelength & 0.71073 & \\
\hline Crystal system & Monoclinic & \\
\hline Space group & $\mathrm{C} 2 / \mathrm{c}$ & \\
\hline \multirow[t]{3}{*}{ Unit cell dimensions } & $a=36.6969(5) \AA$ & $\alpha=90.0^{\circ}$ \\
\hline & $\mathrm{b}=11.5239(2) \AA$ & $\beta=102.0227(7)^{\circ}$ \\
\hline & $c=15.7065(2) \AA$ & $\gamma=90.0^{\circ}$ \\
\hline Volume & $6496.45(17) \AA^{3}$ & \\
\hline $\mathrm{Z}$ & 8 & \\
\hline Density (calculated) & $1.334 \mathrm{Mg} / \mathrm{m}^{3}$ & \\
\hline Absorption coefficient & $0.71 \mathrm{~mm}^{-1}$ & \\
\hline $\mathrm{F}(000)$ & 2732.12 & \\
\hline Crystal size & $0.36 \times 0.20 \times 0.06 \mathrm{~mm}^{3}$ & \\
\hline Diffractometer & Bruker-Nonius X8 Apex2 & \\
\hline $\begin{array}{l}2 \text { Theta range for intensity data } \\
\text { collection }\end{array}$ & 4.53 to $49.95^{\circ}$ & \\
\hline Index ranges & $-51<=\mathrm{h}<=50,0<=\mathrm{k}<=16,0<=1<=22$ & \\
\hline Reflections collected & 90565 & \\
\hline Independent reflections & 9405 & \\
\hline $\begin{array}{l}\text { Observed reflections (I } \\
>1 \text { sigma(I)) }\end{array}$ & 7899 & \\
\hline Solution method & Direct methods (SIR 92) & \\
\hline Refinement method & Full matrix least-squares based on $\mathrm{F}$ & \\
\hline Data/parameters & $7876 / 415$ & \\
\hline Goodness-of-fit & 2.07 & \\
\hline Final $\mathrm{R}$ indices (based on $\mathrm{F}$ ) & $\mathrm{R}=0.054, \mathrm{Rw}=0.055$ & \\
\hline $\mathrm{R}$ indices (all data) & $\mathrm{R}=0.070, \mathrm{Rw}=0.147$ & \\
\hline
\end{tabular}


Table SI-2. Atomic coordinates and equivalent isotropic displacement parameters $\left(\AA^{2}\right)$ for $\mathbf{C u}-\mathbf{1}$.

\begin{tabular}{|c|c|c|c|c|c|}
\hline Atom & $\mathrm{x}$ & $\mathrm{y}$ & $\mathrm{Z}$ & displacement & type \\
\hline $\mathrm{Cu} 1$ & $.340379(6)$ & $.16865(2)$ & $.615106(15)$ & $.01683(12)$ & Uani \\
\hline N21 & $.33483(4)$ & $.03696(14)$ & $.69305(10)$ & $.0180(8)$ & Uani \\
\hline $\mathrm{N} 22$ & $.38251(4)$ & $.22944(14)$ & $.70588(10)$ & $.0186(8)$ & Uani \\
\hline N23 & $.34623(5)$ & $.30016(14)$ & $.53673(10)$ & $.0184(8)$ & Uani \\
\hline N24 & $.29722(4)$ & $.10667(14)$ & $.52371(10)$ & $.0178(8)$ & Uani \\
\hline $\mathrm{C} 1$ & $.31253(6)$ & $-.05801(17)$ & $.67199(13)$ & $.0204(11)$ & Uani \\
\hline $\mathrm{C} 2$ & $.31839(6)$ & $-.13984(18)$ & $.74220(13)$ & $.0236(11)$ & Uani \\
\hline C3 & $.34397(6)$ & $-.09333(18)$ & $.80712(13)$ & $.0229(11)$ & Uani \\
\hline $\mathrm{C} 4$ & $.35474(5)$ & $.01691(17)$ & $.77757(12)$ & $.0187(10)$ & Uani \\
\hline $\mathrm{C} 5$ & $.38179(5)$ & $.08841(17)$ & $.82398(12)$ & $.0189(10)$ & Uani \\
\hline C6 & $.39501(6)$ & $.18865(17)$ & $.78944(13)$ & $.0195(10)$ & Uani \\
\hline $\mathrm{C} 7$ & $.42483(6)$ & $.25908(18)$ & $.83476(13)$ & $.0229(11)$ & Uani \\
\hline $\mathrm{C} 8$ & $.43123(6)$ & $.34190(18)$ & $.77827(14)$ & $.0239(11)$ & Uani \\
\hline $\mathrm{C} 9$ & $.40499(5)$ & $.32437(17)$ & $.69834(13)$ & $.0192(10)$ & Uani \\
\hline $\mathrm{C} 10$ & $.40228(5)$ & $.39435(17)$ & $.62494(13)$ & $.0188(10)$ & Uani \\
\hline C11 & $.37472(5)$ & $.38328(18)$ & $.55024(13)$ & $.0193(10)$ & Uani \\
\hline $\mathrm{C} 12$ & $.36989(6)$ & $.45951(18)$ & $.47779(13)$ & $.0213(10)$ & Uani \\
\hline C13 & $.33838(5)$ & $.42661(17)$ & $.41980(13)$ & $.0189(10)$ & Uani \\
\hline $\mathrm{C} 14$ & $.32396(5)$ & $.32614(16)$ & $.45818(12)$ & $.0170(9)$ & Uani \\
\hline $\mathrm{C} 15$ & $.29153(5)$ & $.26574(18)$ & .41992(12) & $.0193(10)$ & Uani \\
\hline $\mathrm{C} 16$ & $.28019(5)$ & $.16379(17)$ & $.44882(12)$ & $.0176(9)$ & Uani \\
\hline $\mathrm{C} 17$ & $.24723(5)$ & $.09739(18)$ & $.40035(13)$ & $.0217(10)$ & Uani \\
\hline $\mathrm{C} 18$ & $.25352(5)$ & $-.02548(17)$ & $.43882(13)$ & $.0189(10)$ & Uani \\
\hline C19 & $.28038(5)$ & $.00090(17)$ & $.52495(13)$ & $.0192(10)$ & Uani \\
\hline $\mathrm{C} 20$ & $.28761(6)$ & $-.07533(17)$ & $.59287(13)$ & $.0217(11)$ & Uani \\
\hline $\mathrm{C} 21$ & $.39949(6)$ & $.05528(18)$ & $.91561(13)$ & $.0207(11)$ & Uani \\
\hline $\mathrm{C} 22$ & $.38190(6)$ & $.07580(20)$ & $.98392(14)$ & $.0271(12)$ & Uani \\
\hline $\mathrm{C} 23$ & $.39889(6)$ & $.0456(2)$ & $1.06841(14)$ & $.0305(12)$ & Uani \\
\hline $\mathrm{C} 24$ & $.43373(6)$ & $-.00535(19)$ & $1.08715(13)$ & $.0274(12)$ & Uani \\
\hline $\mathrm{C} 25$ & $.45103(6)$ & $-.02735(19)$ & $1.01857(14)$ & $.0293(12)$ & Uani \\
\hline $\mathrm{C} 26$ & $.43448(6)$ & $.00309(19)$ & $.93408(13)$ & $.0283(12)$ & Uani \\
\hline $\mathrm{C} 27$ & $.45246(7)$ & $-.0361(2)$ & $1.17886(14)$ & $.0368(13)$ & Uani \\
\hline $\mathrm{C} 28$ & $.43051(5)$ & $.48942(17)$ & $.62724(13)$ & $.0201(10)$ & Uani \\
\hline $\mathrm{C} 29$ & $.46511(6)$ & $.46338(18)$ & $.60736(13)$ & $.0217(10)$ & Uani \\
\hline $\mathrm{C} 30$ & $.49091(6)$ & $.55204(19)$ & $.60817(14)$ & $.0243(11)$ & Uani \\
\hline C31 & $.48347(6)$ & $.66540(18)$ & $.62913(13)$ & $.0250(11)$ & Uani \\
\hline $\mathrm{C} 32$ & $.44934(6)$ & $.68874(18)$ & $.64900(15)$ & $.0278(12)$ & Uani \\
\hline C33 & $.42263(6)$ & .60285(19) & $.64956(14)$ & $.0253(11)$ & Uani \\
\hline C34 & $.47443(6)$ & $.34029(18)$ & $.58584(16)$ & $.0298(12)$ & Uani \\
\hline $\mathrm{C} 35$ & $.51131(7)$ & $.76087(20)$ & $.62827(15)$ & $.0334(13)$ & Uani \\
\hline $\mathrm{C} 36$ & $.38628(7)$ & $.6345(2)$ & $67393(20)$ & $.0440(17)$ & Uani \\
\hline C37 & $.32204(6)$ & $.48185(19)$ & $.33600(14)$ & $.0245(11)$ & Uani \\
\hline $\mathrm{C} 38$ & $.33447(7)$ & $.6038(2)$ & $.32265(16)$ & $.0401(14)$ & Uani \\
\hline $\mathrm{O} 1$ & $.29947(5)$ & $.43386(14)$ & $.27992(10)$ & $.0378(9)$ & Uani \\
\hline C39 & $.21770(6)$ & $-.08401(18)$ & .44975(13) & $.0235(11)$ & Uani \\
\hline
\end{tabular}




$\begin{array}{cccccc}\text { C40 } & .27400(6) & -.10213(19) & .38389(13) & .0239(11) & \text { Uani } \\ \mathrm{H} 2 & .306 & -.214 & .743 & .0338 & \text { Uiso } \\ \mathrm{H} 3 & .355 & -.125 & .863 & .0329 & \text { Uiso } \\ \mathrm{H} 7 & .438 & .246 & .894 & .0319 & \text { Uiso } \\ \mathrm{H} 8 & .449 & .403 & .788 & .0328 & \text { Uiso } \\ \mathrm{H} 12 & .386 & .523 & .469 & .0314 & \text { Uiso } \\ \mathrm{H} 15 & .277 & .294 & .366 & .0287 & \text { Uiso } \\ \mathrm{H} 17 \mathrm{a} & .225 & .132 & .413 & .0311 & \text { Uiso } \\ \mathrm{H} 17 \mathrm{~b} & .245 & .097 & .339 & .0311 & \text { Uiso } \\ \mathrm{H} 20 & .275 & -.149 & .591 & .0318 & \text { Uiso } \\ \mathrm{H} 22 & .358 & .112 & .973 & .0371 & \text { Uiso } \\ \mathrm{H} 23 & .387 & .067 & 1.115 & .0409 & \text { Uiso } \\ \mathrm{H} 25 & .476 & -.060 & 1.034 & .0381 & \text { Uiso } \\ \mathrm{H} 26 & .447 & -.007 & .887 & .0385 & \text { Uiso } \\ \mathrm{H} 27 \mathrm{a} & .479 & -.040 & 1.178 & .0456 & \text { Uiso } \\ \mathrm{H} 27 \mathrm{~b} & .444 & .011 & 1.222 & .0456 & \text { Uiso } \\ \mathrm{H} 27 \mathrm{c} & .446 & -.113 & 1.195 & .0456 & \text { Uiso } \\ \mathrm{H} 30 & .516 & .536 & .601 & .0340 & \text { Uiso } \\ \mathrm{H} 32 & .442 & .767 & .659 & .0370 & \text { Uiso } \\ \mathrm{H} 34 \mathrm{a} & .454 & .305 & .547 & .0406 & \text { Uiso } \\ \mathrm{H} 34 \mathrm{~b} & .495 & .338 & .556 & .0406 & \text { Uiso } \\ \mathrm{H} 34 \mathrm{c} & .480 & .303 & .642 & .0406 & \text { Uiso } \\ \mathrm{H} 35 \mathrm{a} & .535 & .732 & .624 & .0434 & \text { Uiso } \\ \mathrm{H} 35 \mathrm{~b} & .502 & .817 & .584 & .0434 & \text { Uiso } \\ \mathrm{H} 35 \mathrm{c} & .513 & .804 & .681 & .0434 & \text { Uiso } \\ \mathrm{H} 36 \mathrm{a} & .387 & .712 & .696 & .0550 & \text { Uiso } \\ \mathrm{H} 36 \mathrm{~b} & .364 & .645 & .629 & .0550 & \text { Uiso } \\ \mathrm{H} 36 \mathrm{c} & .378 & .568 & .702 & .0550 & \text { Uiso } \\ \mathrm{H} 38 \mathrm{a} & .361 & .597 & .328 & .0484 & \text { Uiso } \\ \mathrm{H} 38 \mathrm{~b} & .323 & .626 & .264 & .0484 & \text { Uiso } \\ \mathrm{H} 38 \mathrm{c} & .323 & .655 & .358 & .0484 & \text { Uiso } \\ \mathrm{H} 39 \mathrm{a} & .206 & -.039 & .487 & .0334 & \text { Uiso } \\ \mathrm{H} 39 \mathrm{~b} & .202 & -.087 & .393 & .0334 & \text { Uiso } \\ \mathrm{H} 39 \mathrm{c} & .225 & -.158 & .476 & .0334 & \text { Uiso } \\ \mathrm{H} 40 \mathrm{a} & .296 & -.065 & .374 & .0334 & \text { Uiso } \\ \mathrm{H} 40 \mathrm{~b} & .281 & -.175 & .411 & .0334 & \text { Uiso } \\ \mathrm{H} 40 \mathrm{c} & .258 & -.120 & .330 & .0334 & \text { Uiso } \\ & & & & & \end{array}$


Table SI-3 Bond lengths for Cu-1.

\begin{tabular}{cccc}
\hline Bond & Length $(\AA)$ & Bond & Length $(\AA)$ \\
\hline Cu1-N21 & $1.9867(16)$ & C13-C37 & $1.472(3)$ \\
Cu1-N22 & $1.9990(16)$ & C14-C15 & $1.401(3)$ \\
Cu1-N23 & $1.9921(16)$ & C15-C16 & $1.356(3)$ \\
Cu1-N24 & $2.0327(16)$ & C16-C17 & $1.498(3)$ \\
N21-C1 & $1.365(3)$ & C17-C18 & $1.538(3)$ \\
N21-C4 & $1.395(2)$ & C18-C19 & $1.529(3)$ \\
N22-C6 & $1.379(3)$ & C18-C39 & $1.518(3)$ \\
N22-C9 & $1.390(3)$ & C18-C40 & $1.536(3)$ \\
N23-C11 & $1.401(3)$ & C19-C20 & $1.365(3)$ \\
N23-C14 & $1.364(3)$ & C21-C22 & $1.383(3)$ \\
N24-C16 & $1.379(3)$ & C21-C26 & $1.393(3)$ \\
N24-C19 & $1.369(3)$ & C22-C23 & $1.388(3)$ \\
C1-C2 & $1.433(3)$ & C23-C24 & $1.382(3)$ \\
C1-C20 & $1.395(3)$ & C24-C25 & $1.383(3)$ \\
C2-C3 & $1.345(3)$ & C24-C27 & $1.504(3)$ \\
C3-C4 & $1.436(3)$ & C25-C26 & $1.385(3)$ \\
C4-C5 & $1.376(3)$ & C28-C29 & $1.402(3)$ \\
C5-C6 & $1.405(3)$ & C28-C33 & $1.399(3)$ \\
C5-C21 & $1.500(3)$ & C29-C30 & $1.391(3)$ \\
C6-C7 & $1.428(3)$ & C29-C34 & $1.514(3)$ \\
C7-C8 & $1.356(3)$ & C30-C31 & $1.388(3)$ \\
C8-C9 & $1.429(3)$ & C31-C32 & $1.379(3)$ \\
C9-C10 & $1.393(3)$ & C31-C35 & $1.503(3)$ \\
C10-C11 & $1.386(3)$ & C32-C33 & $1.394(3)$ \\
C10-C28 & $1.503(3)$ & C33-C36 & $1.507(3)$ \\
C11-C12 & $1.419(3)$ & C37-C38 & $1.505(3)$ \\
C12-C13 & $1.368(3)$ & C37-O1 & $1.210(3)$ \\
C13-C14 & $1.455(3)$ & &
\end{tabular}


Table SI-4. Bond angles for Cu-1.

\begin{tabular}{|c|c|c|c|}
\hline Bond & Angles & Bond & Angles \\
\hline N21-Cu1-N22 & $89.51(7)$ & C14-C13-C37 & $126.78(18)$ \\
\hline N21-Cu1-N23 & 179.61(7) & N23-C14-C13 & $110.38(16)$ \\
\hline N21-Cu1-N24 & $90.12(6)$ & N23-C14-C15 & $125.05(18)$ \\
\hline $\mathrm{N} 22-\mathrm{Cu} 1-\mathrm{N} 23$ & $90.41(7)$ & C13-C14-C15 & $124.56(18)$ \\
\hline N22-Cu1-N24 & 179.43(6) & C14-C15-C16 & $125.40(18)$ \\
\hline N23-Cu1-N24 & $89.96(7)$ & N24-C16-C15 & $125.67(18)$ \\
\hline Cu1-N21-C1 & $126.59(13)$ & N24-C16-C17 & $111.36(17)$ \\
\hline Cu1-N21-C4 & $127.77(13)$ & C15-C16-C17 & $122.96(18)$ \\
\hline C1-N21-C4 & $105.45(16)$ & C16-C17-C18 & $103.37(16)$ \\
\hline Cu1-N22-C6 & $127.85(13)$ & C17-C18-C19 & $100.43(15)$ \\
\hline Cu1-N22-C9 & $126.84(13)$ & C17-C18-C39 & $113.01(17)$ \\
\hline C6-N22-C9 & $105.29(16)$ & $\mathrm{C} 17-\mathrm{C} 18-\mathrm{C} 40$ & $111.08(16)$ \\
\hline Cu1-N23-C11 & $126.85(13)$ & C19-C18-C39 & $113.71(16)$ \\
\hline Cu1-N23-C14 & $127.20(13)$ & C19-C18-C40 & $108.08(16)$ \\
\hline C11-N23-C14 & $105.94(16)$ & C39-C18-C40 & $110.14(16)$ \\
\hline Cu1-N24-C16 & $125.65(13)$ & N24-C19-C18 & $111.97(17)$ \\
\hline Cu1-N24-C19 & $126.19(13)$ & N24-C19-C20 & $124.73(18)$ \\
\hline C16-N24-C19 & $108.15(16)$ & C18-C19-C20 & $123.23(18)$ \\
\hline N21-C1-C2 & $110.78(17)$ & C1-C20-C19 & $126.06(18)$ \\
\hline N21-C1-C20 & $125.39(18)$ & $\mathrm{C} 5-\mathrm{C} 21-\mathrm{C} 22$ & $121.47(18)$ \\
\hline C2-C1-C20 & $123.83(18)$ & C5-C21-C26 & $120.41(18)$ \\
\hline C1-C2-C3 & $106.88(18)$ & C22-C21-C26 & $118.12(19)$ \\
\hline C2-C3-C4 & $107.64(18)$ & $\mathrm{C} 21-\mathrm{C} 22-\mathrm{C} 23$ & $120.6(2)$ \\
\hline N21-C4-C3 & $109.23(17)$ & C22-C23-C24 & $121.44(20)$ \\
\hline N21-C4-C5 & $125.58(18)$ & $\mathrm{C} 23-\mathrm{C} 24-\mathrm{C} 25$ & $117.81(19)$ \\
\hline C3-C4-C5 & $125.12(18)$ & $\mathrm{C} 23-\mathrm{C} 24-\mathrm{C} 27$ & $121.5(2)$ \\
\hline C4-C5-C6 & $123.83(18)$ & $\mathrm{C} 25-\mathrm{C} 24-\mathrm{C} 27$ & $120.7(2)$ \\
\hline C4-C5-C21 & $118.44(18)$ & $\mathrm{C} 24-\mathrm{C} 25-\mathrm{C} 26$ & $121.3(2)$ \\
\hline C6-C5-C21 & $117.67(18)$ & $\mathrm{C} 21-\mathrm{C} 26-\mathrm{C} 25$ & $120.69(19)$ \\
\hline N22-C6-C5 & $125.06(18)$ & $\mathrm{C} 10-\mathrm{C} 28-\mathrm{C} 29$ & $119.36(18)$ \\
\hline N22-C6-C7 & $110.42(17)$ & C10-C28-C33 & $120.65(18)$ \\
\hline C5-C6-C7 & $124.43(18)$ & C29-C28-C 33 & $119.99(18)$ \\
\hline C6-C7-C8 & $107.05(18)$ & C28-C29-C30 & $119.15(19)$ \\
\hline C7-C8-C9 & $107.36(18)$ & C28-C29-C34 & $120.50(18)$ \\
\hline N22-C9-C8 & $109.86(17)$ & C30-C29-C34 & $120.35(19)$ \\
\hline N22-C9-C10 & $125.78(18)$ & C29-C30-C31 & $121.74(19)$ \\
\hline C8-C9-C10 & $124.35(18)$ & C30-C31-C32 & $118.05(19)$ \\
\hline C9-C10-C11 & $124.10(18)$ & C30-C31-C35 & $121.26(20)$ \\
\hline C9-C10-C28 & $118.16(17)$ & C32-C31-C35 & $120.68(20)$ \\
\hline C11-C10-C28 & $117.72(17)$ & C31-C32-C33 & $122.40(20)$ \\
\hline N23-C11-C10 & $125.52(18)$ & $\mathrm{C} 28-\mathrm{C} 33-\mathrm{C} 32$ & 118.64(19) \\
\hline $\mathrm{N} 23-\mathrm{C} 11-\mathrm{C} 12$ & $109.70(17)$ & C28-C33-C36 & $122.00(19)$ \\
\hline $\mathrm{C} 10-\mathrm{C} 11-\mathrm{C} 12$ & $124.68(18)$ & C32-C33-C36 & $119.35(20)$ \\
\hline C11-C12-C13 & $108.03(17)$ & C13-C37-C38 & $116.69(19)$ \\
\hline C12-C13-C14 & 105.94(17) & C13-C37-O1 & $122.87(19)$ \\
\hline C12-C13-C37 & $127.28(18)$ & C38-C37-O1 & $120.44(19)$ \\
\hline
\end{tabular}




\section{References}

(S1) Moss, G. P. Pure Appl. Chem. 1987, 59, 779-832.

(S2) (a) Fenyo, D.; Chait, B. T.; Johnson, T. E.; Lindsey, J. S. J. Porphyrins Phthalocyanines 1997, 1, 93-99. (b) Srinivasan, N.; Haney, C. A.; Lindsey, J. S.; Zhang, W.; Chait, B. T. J. Porphyrins Phthalocyanines 1999, 3, 283-291.

(S3) Balaban, T. S.; Linke-Schaetzel, M.; Bhise, A. D.; Vanthuyne, N.; Roussel, C. Eur. J. Org. Chem. 2004, 3919-3930.

(S4) Senge, M. O. In The Porphyrin Handbook; Kadish, K. M., Smith, K. M., Guilard, R., Eds.; Academic Press: San Diego, CA, 2000; Vol. 10, pp 1-218.

(S5) Bruker-Nonius, SAINT+ version 7.07B (2004), Bruker-Nonius, Madison, WI 53711, USA.

(S6) Bruker-Nonius, SADABS version 2.10 (2004), Bruker-Nonius, Madison, WI 53711, USA.

(S7) Altomare, A.; Cascarano, G.; Giacovazzo, C.; Guagliardi, A.; Burla, M. C.; Polidori, G.; Camalli, G. J. Appl. Cryst. 1994, 27, 435-436.

(S8) Gabe, E. J.; Le Page, Y.; Charland, J.-P.; Lee, F. L; White, P. S. J. Appl. Cryst. 1989, 22, 384-387. 


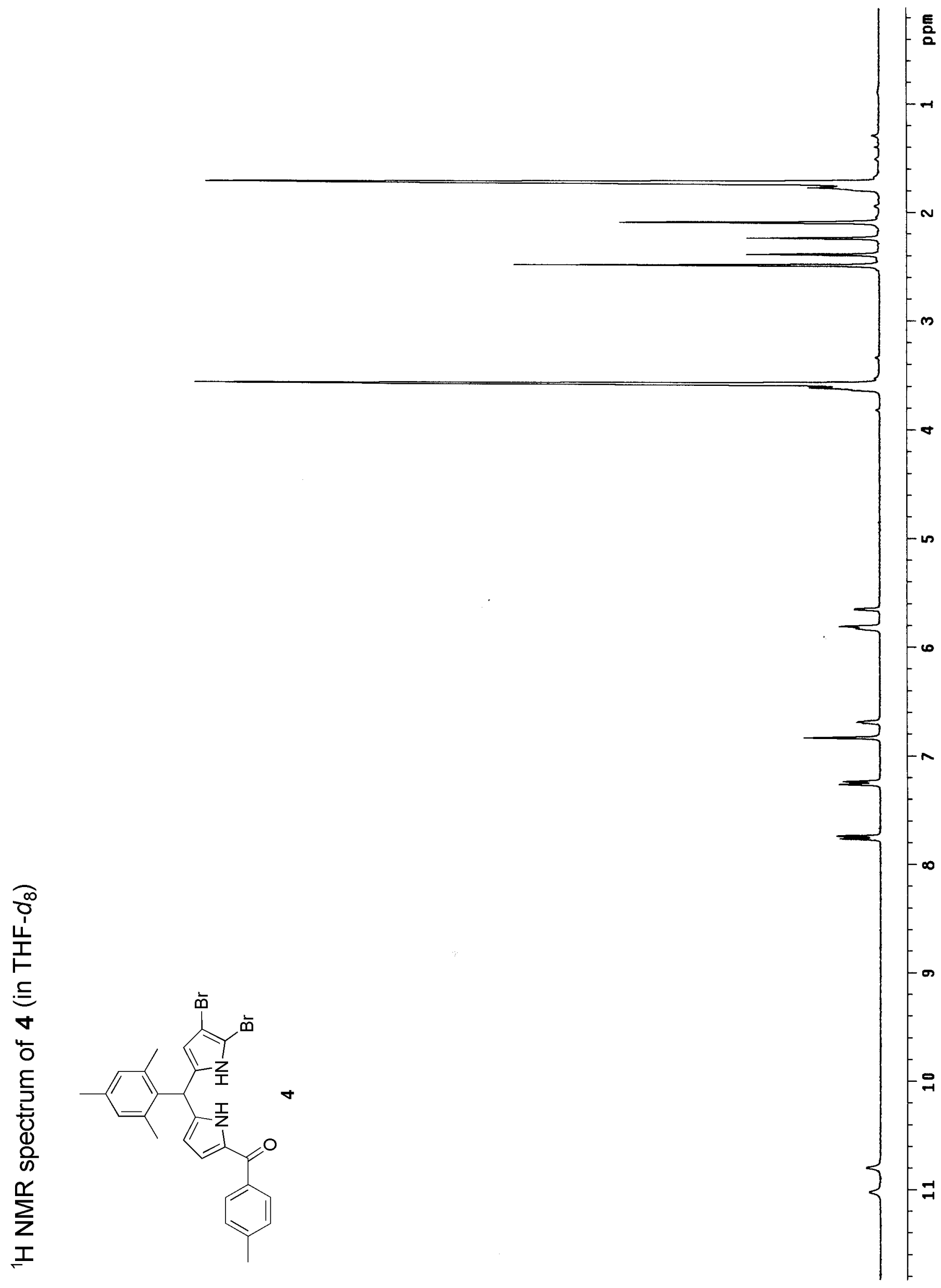




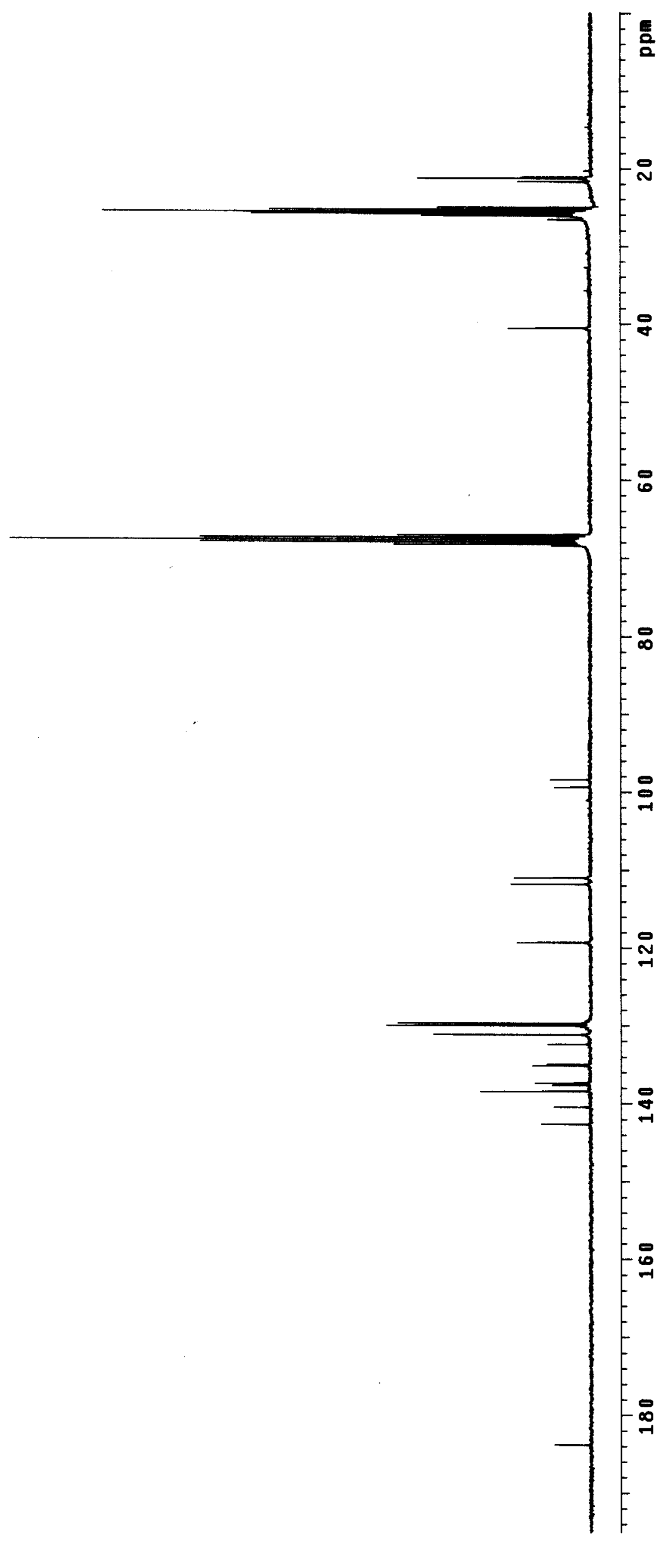



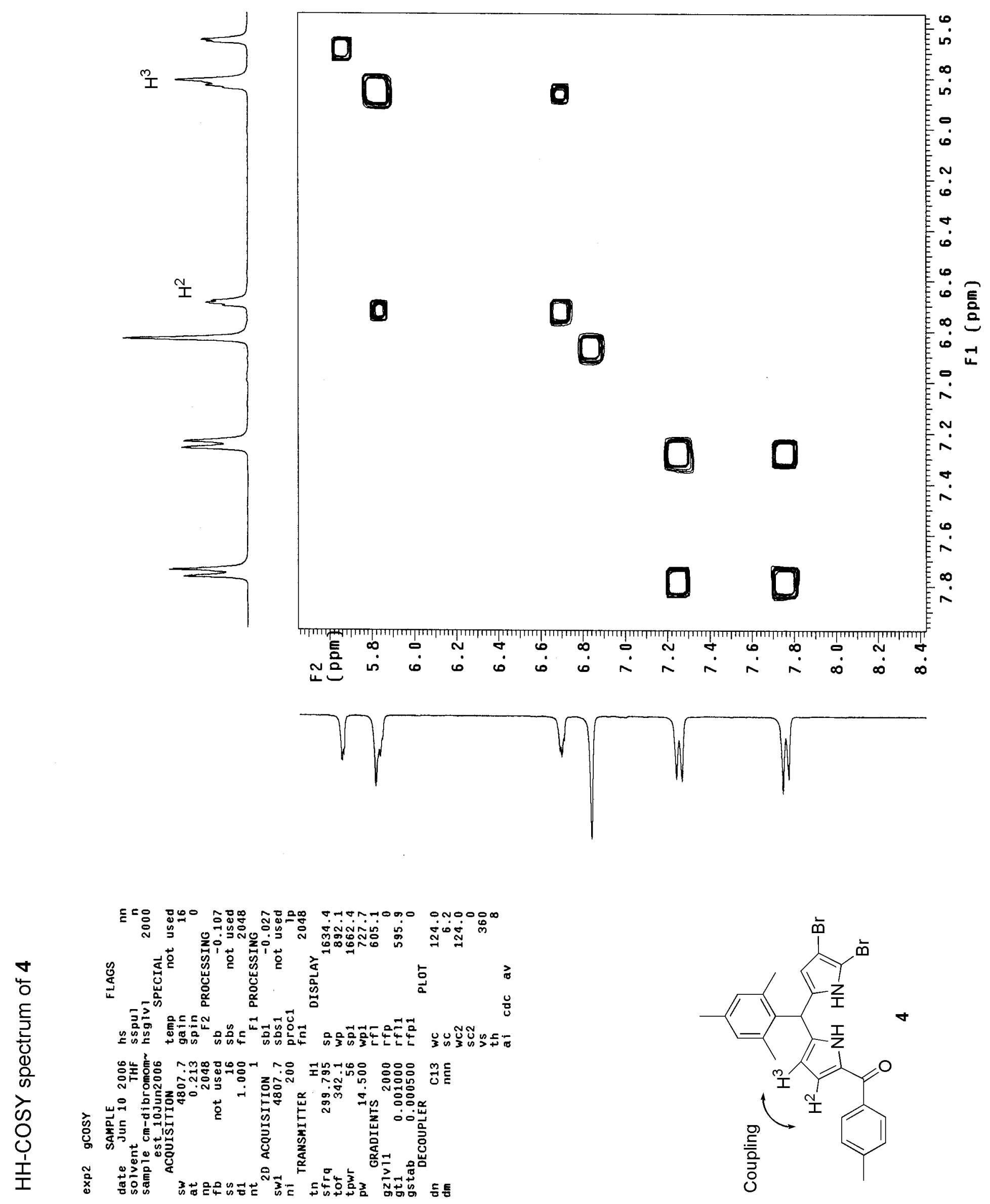

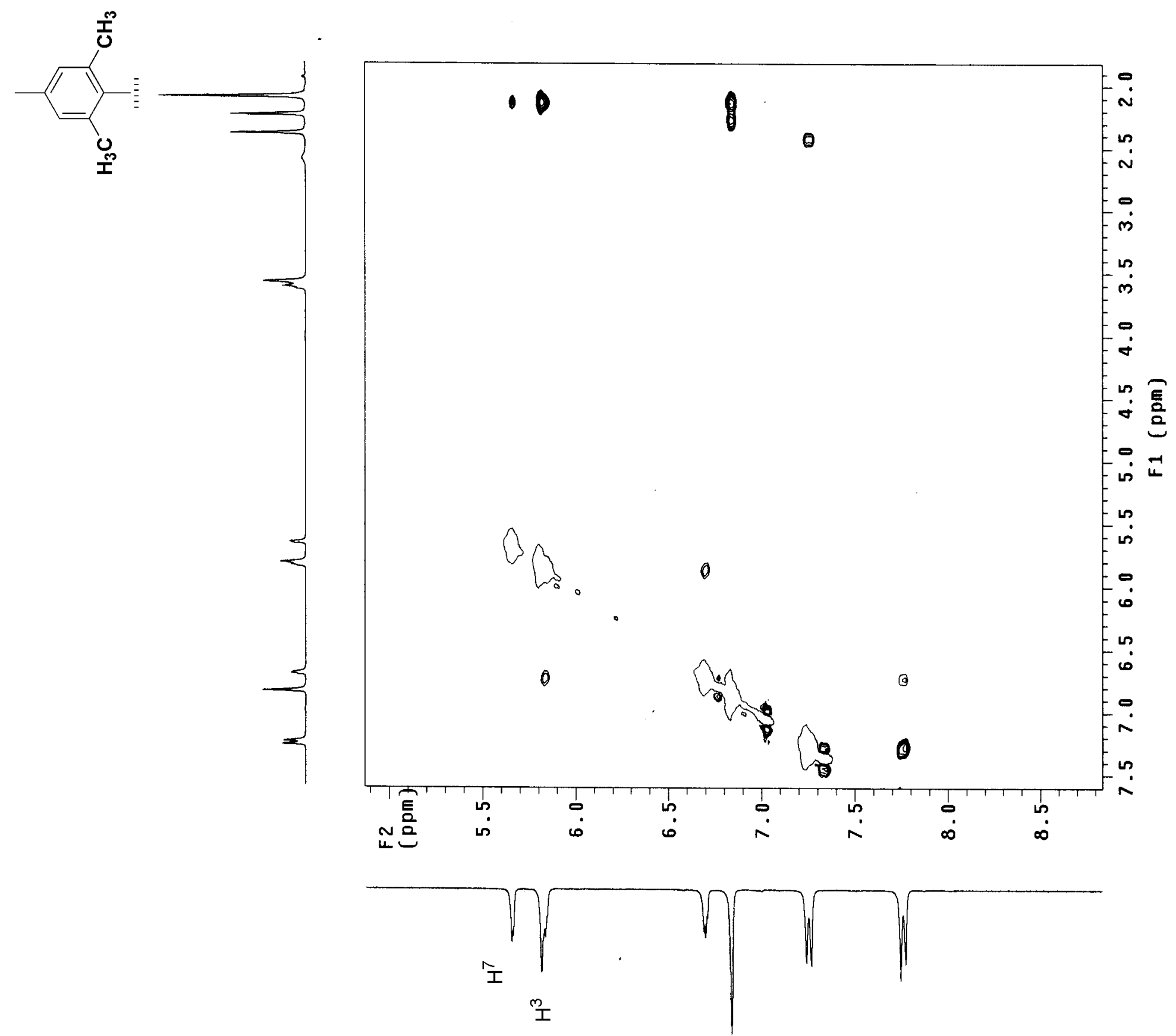

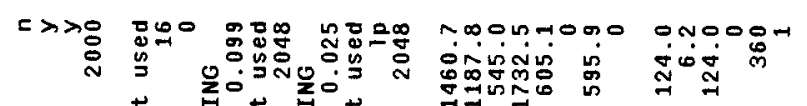
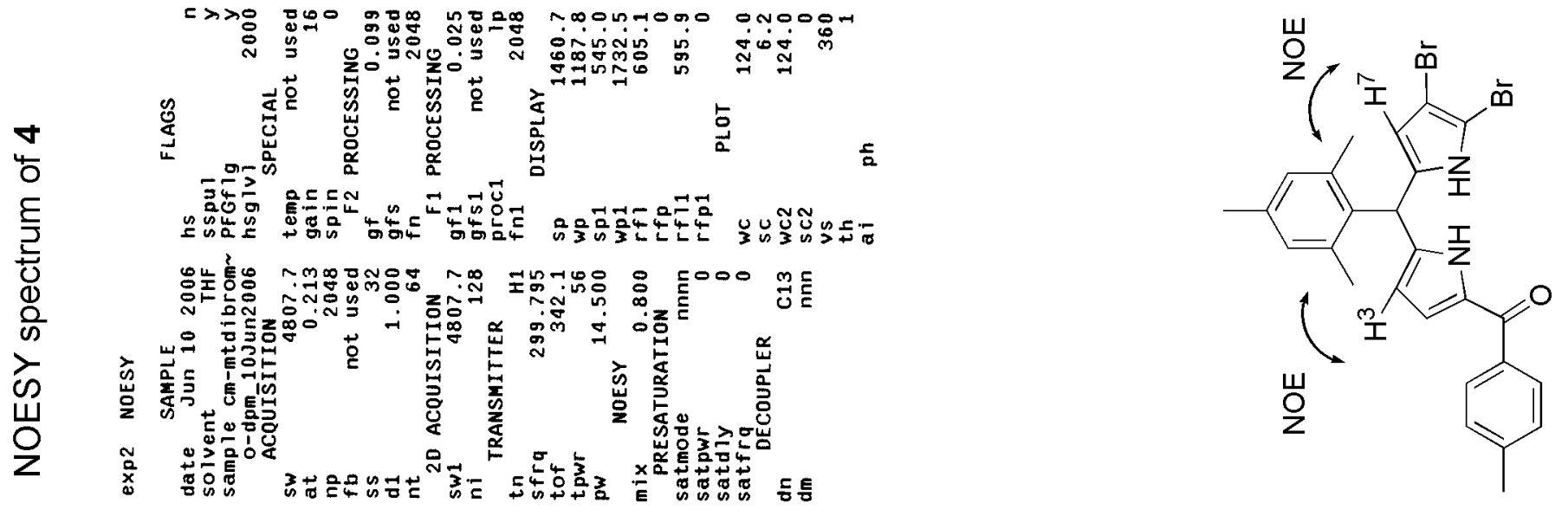


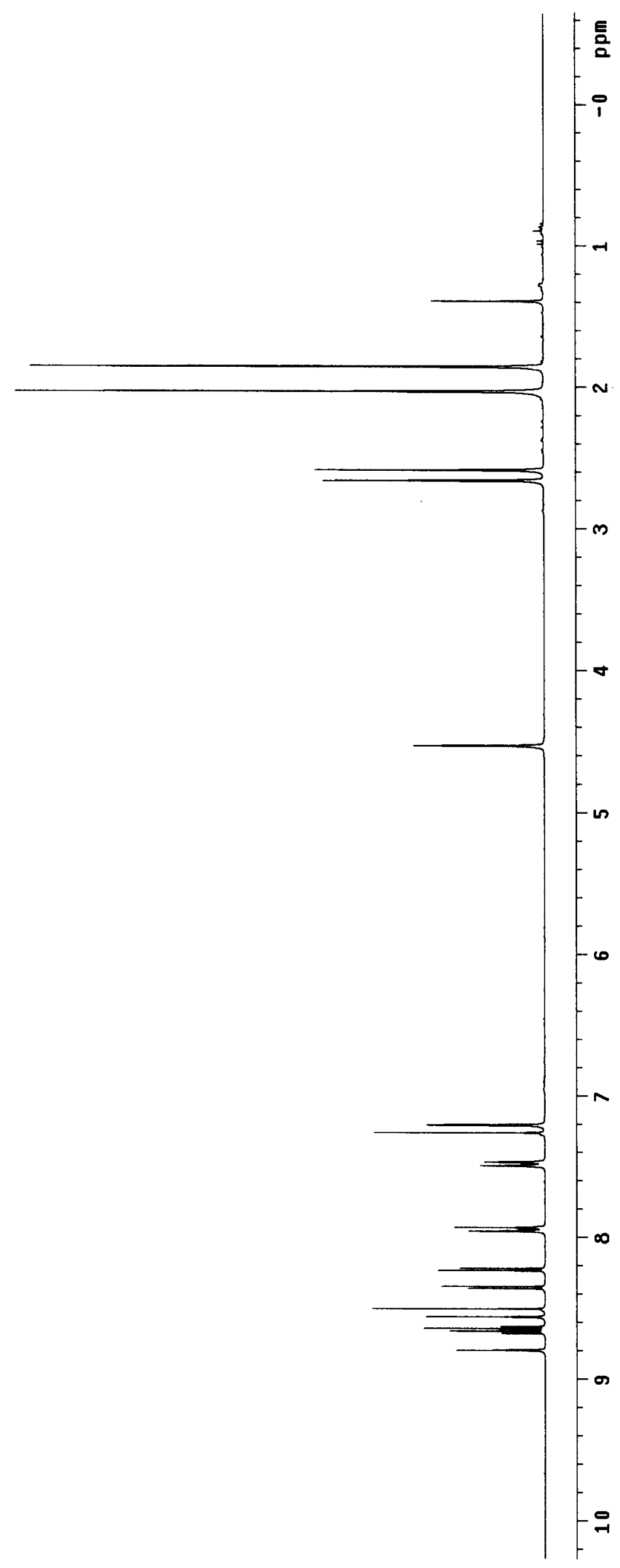




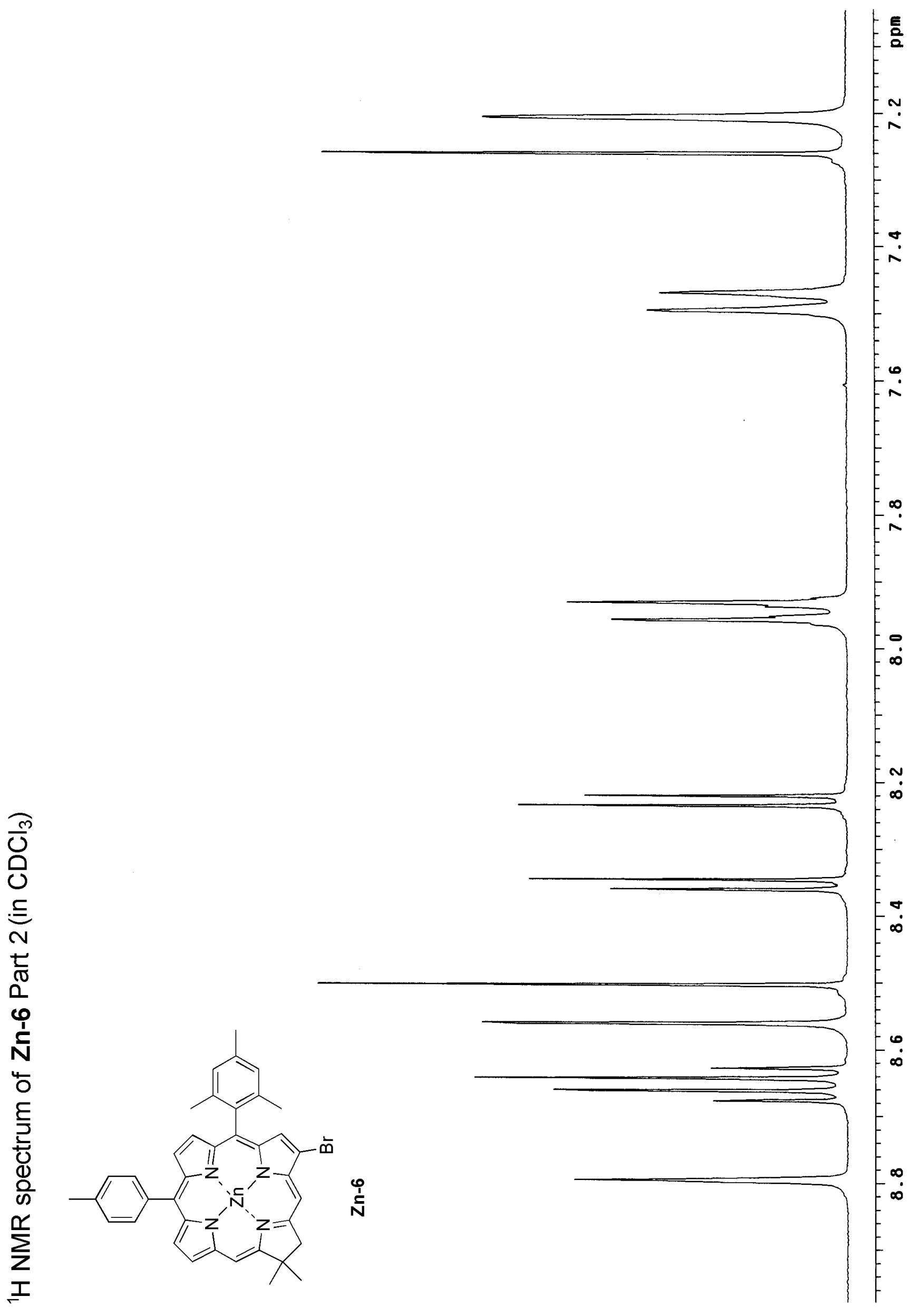



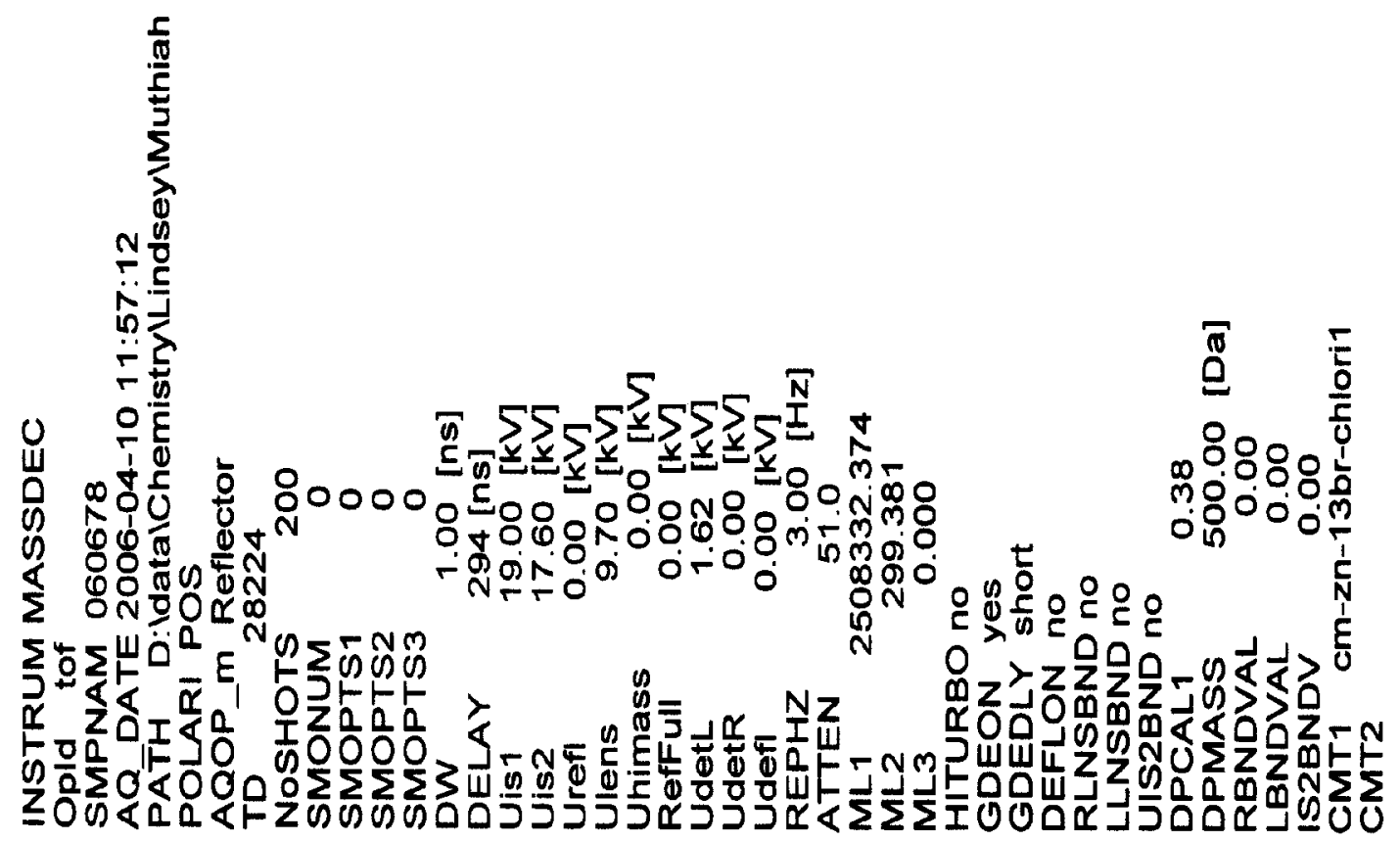

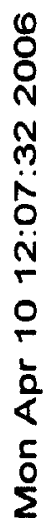

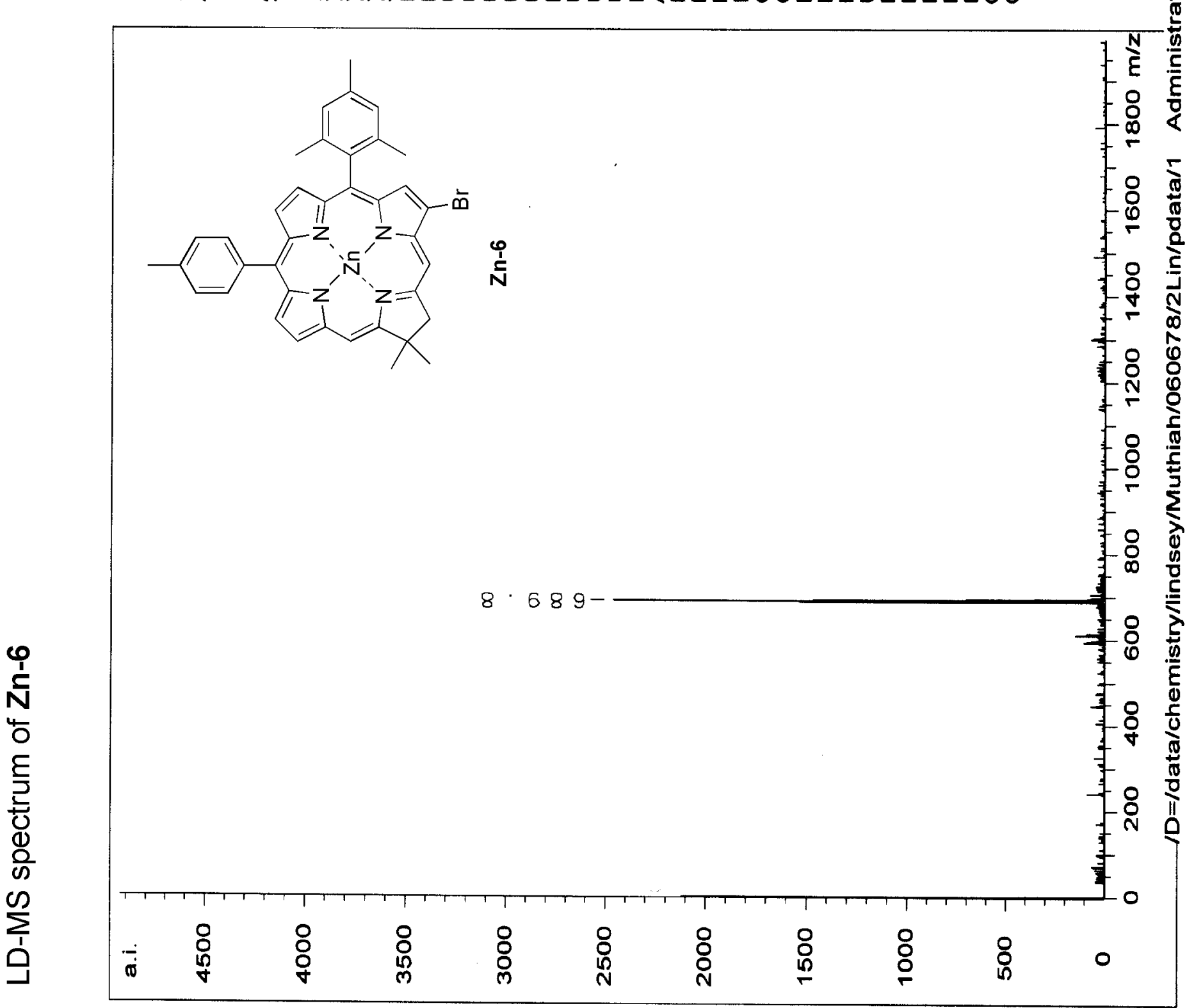



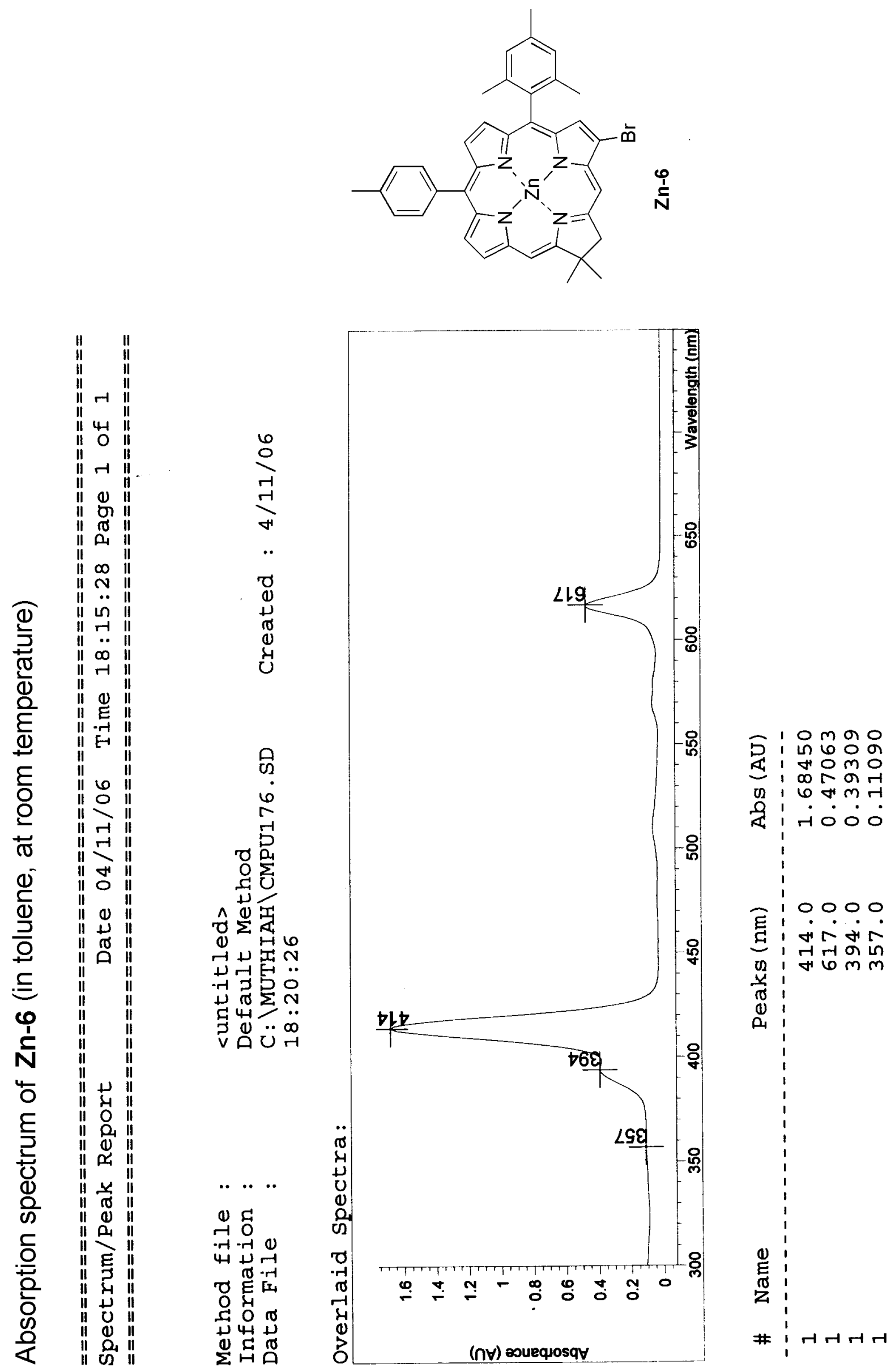


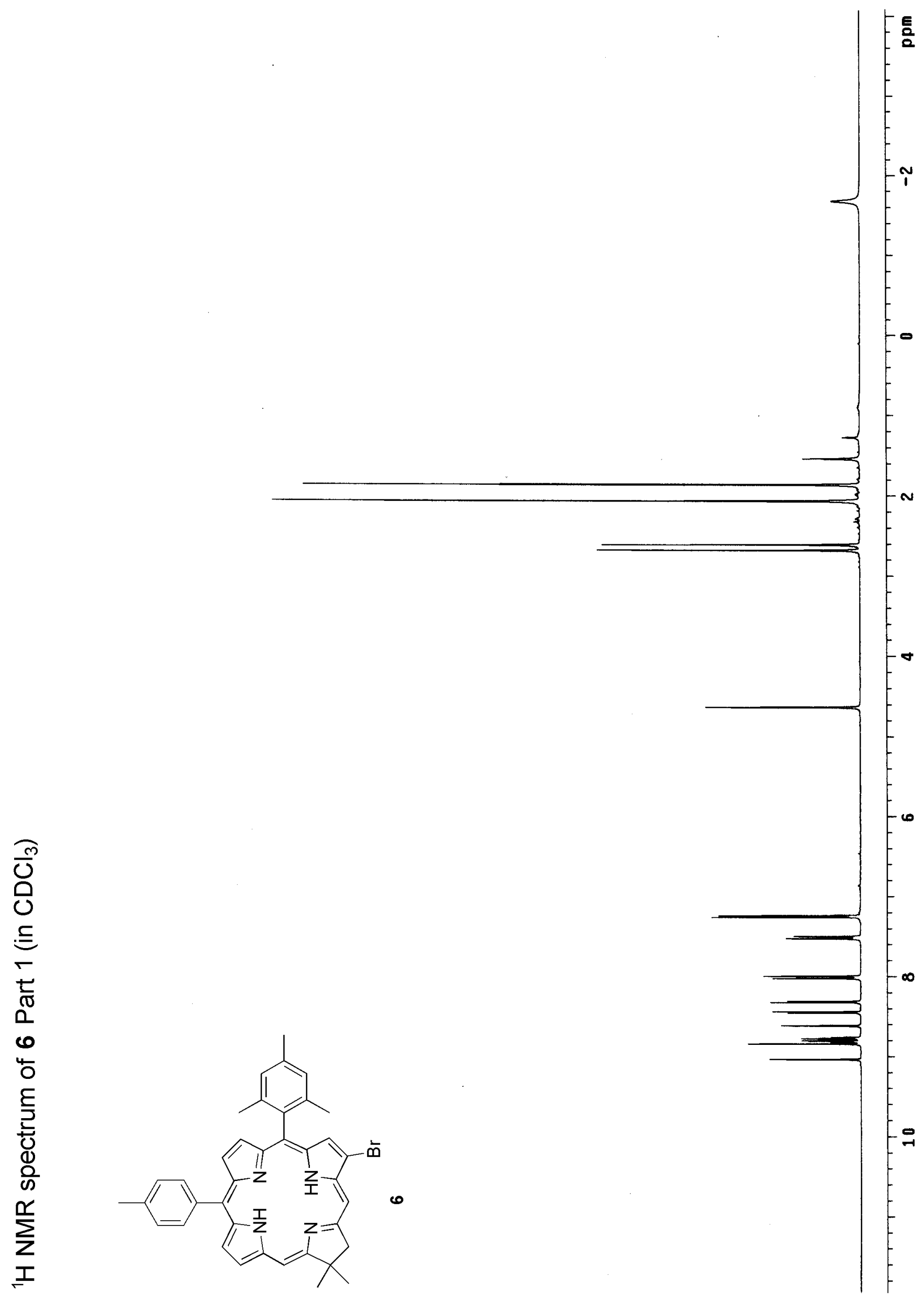




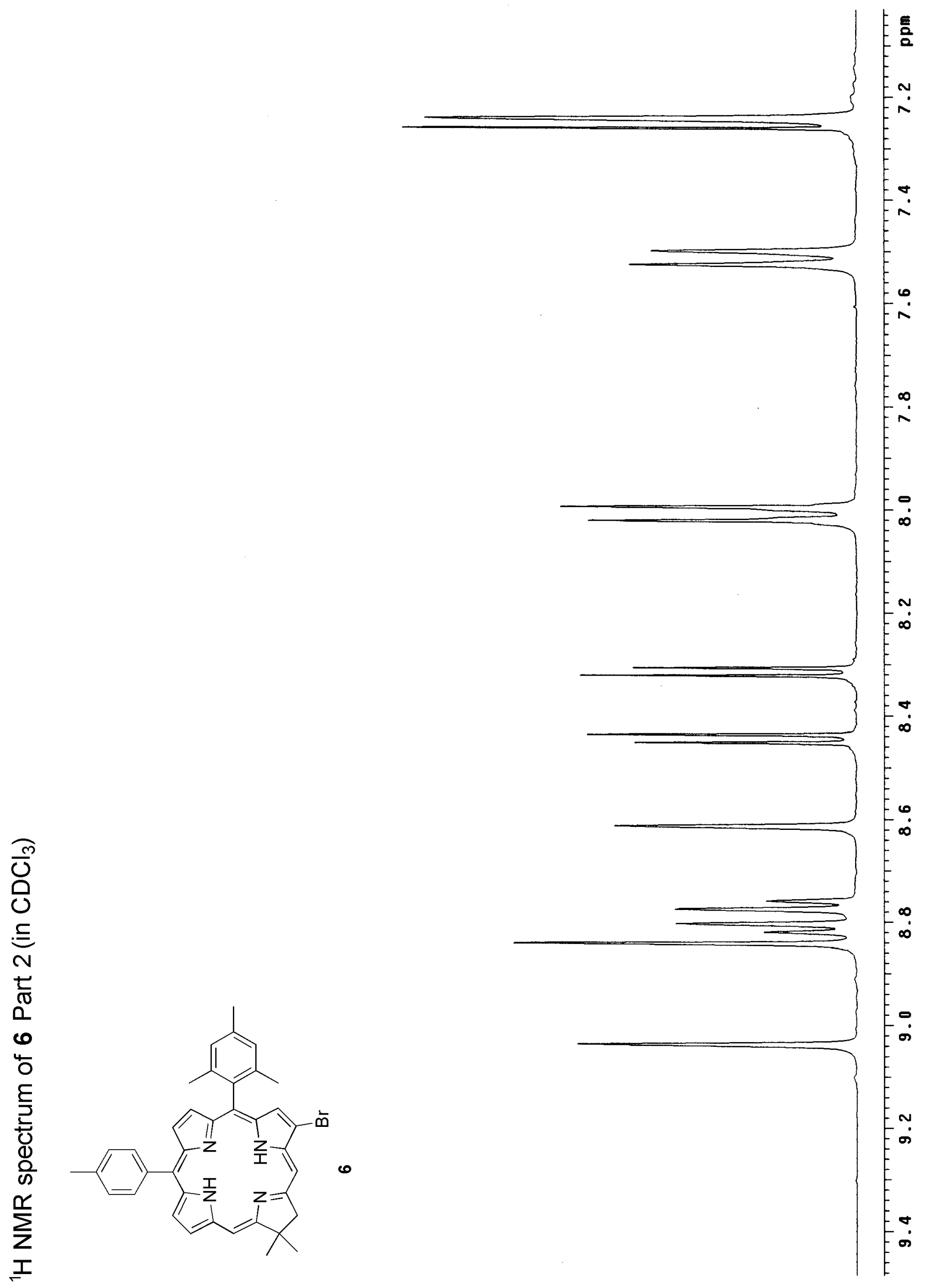




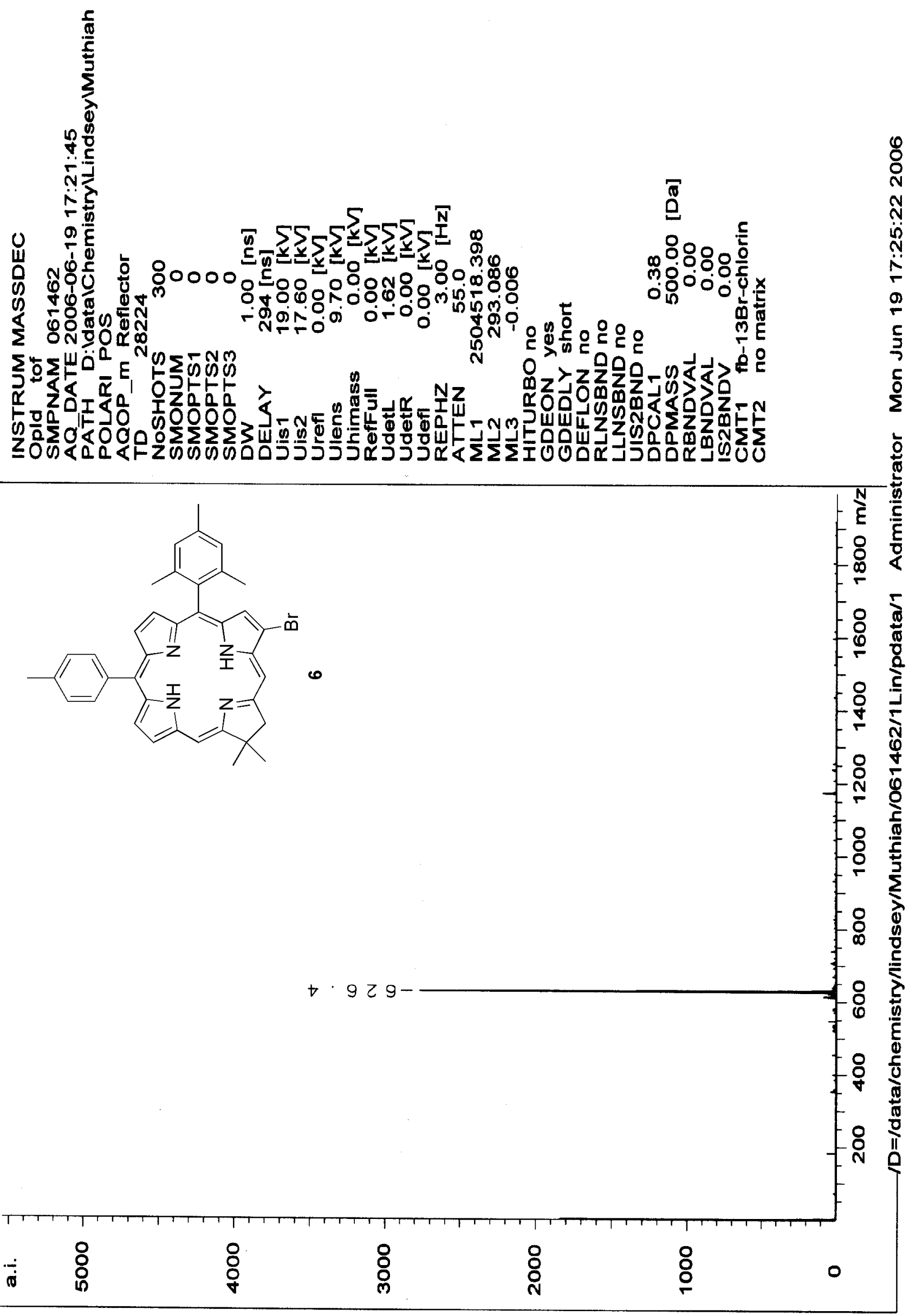



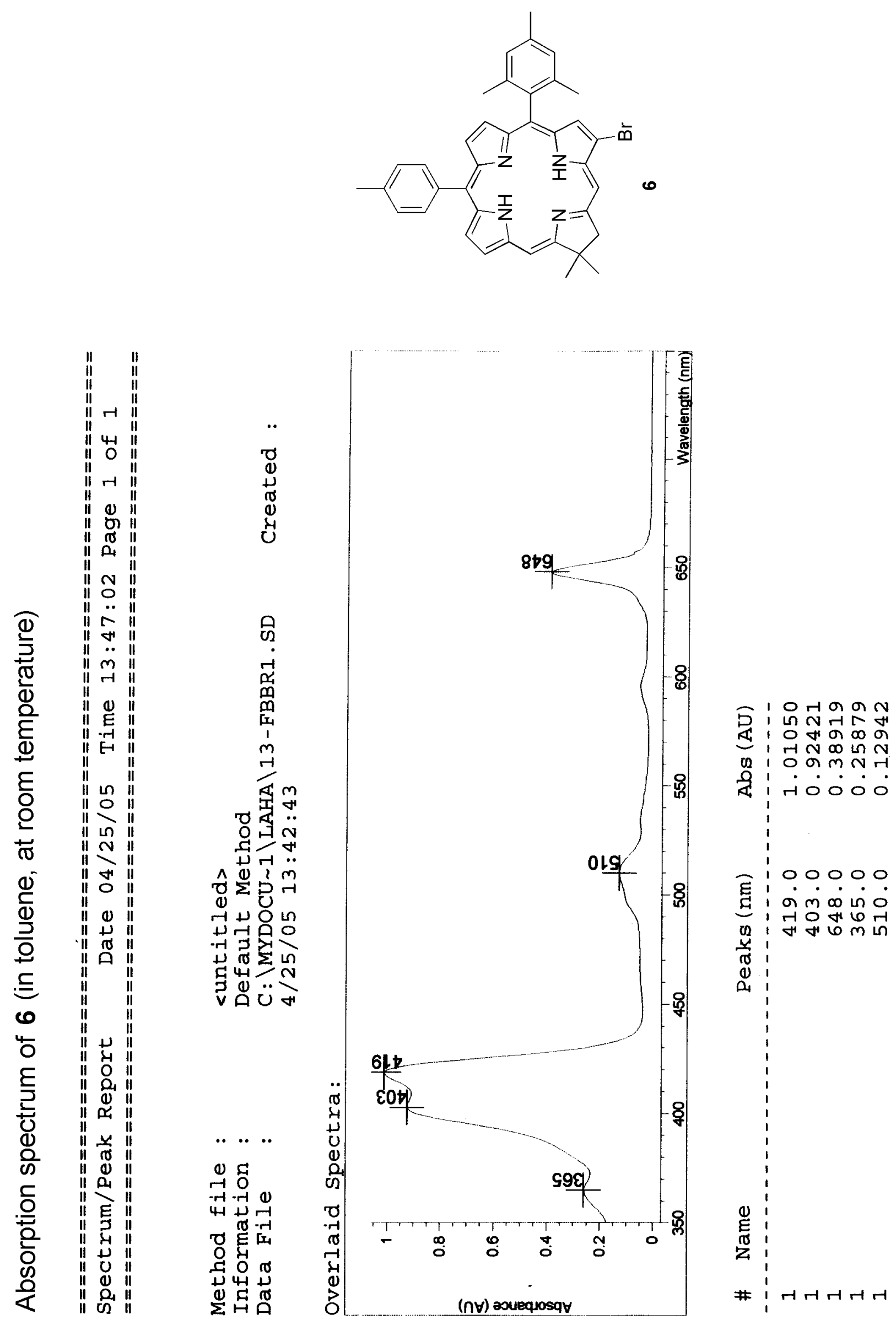


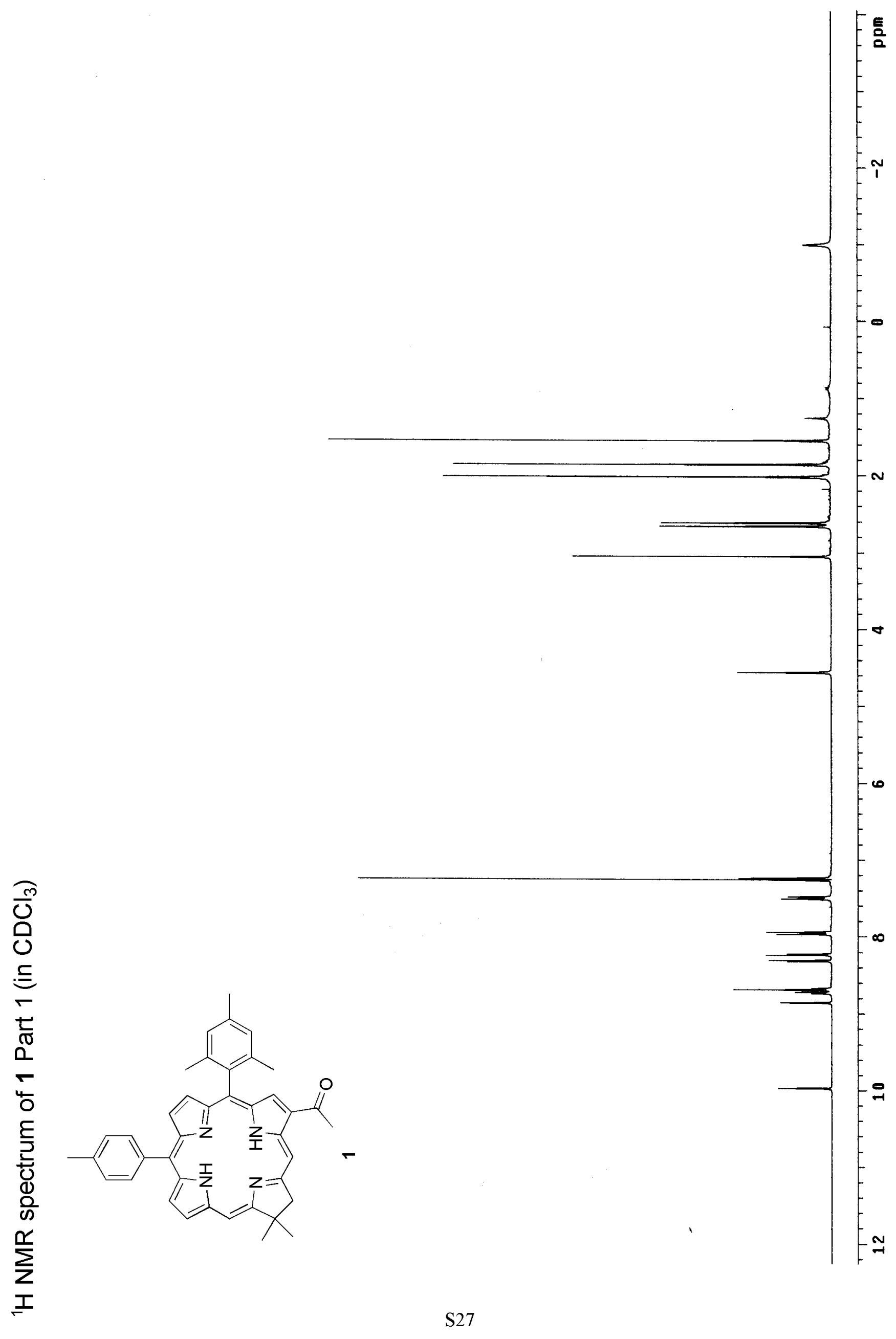




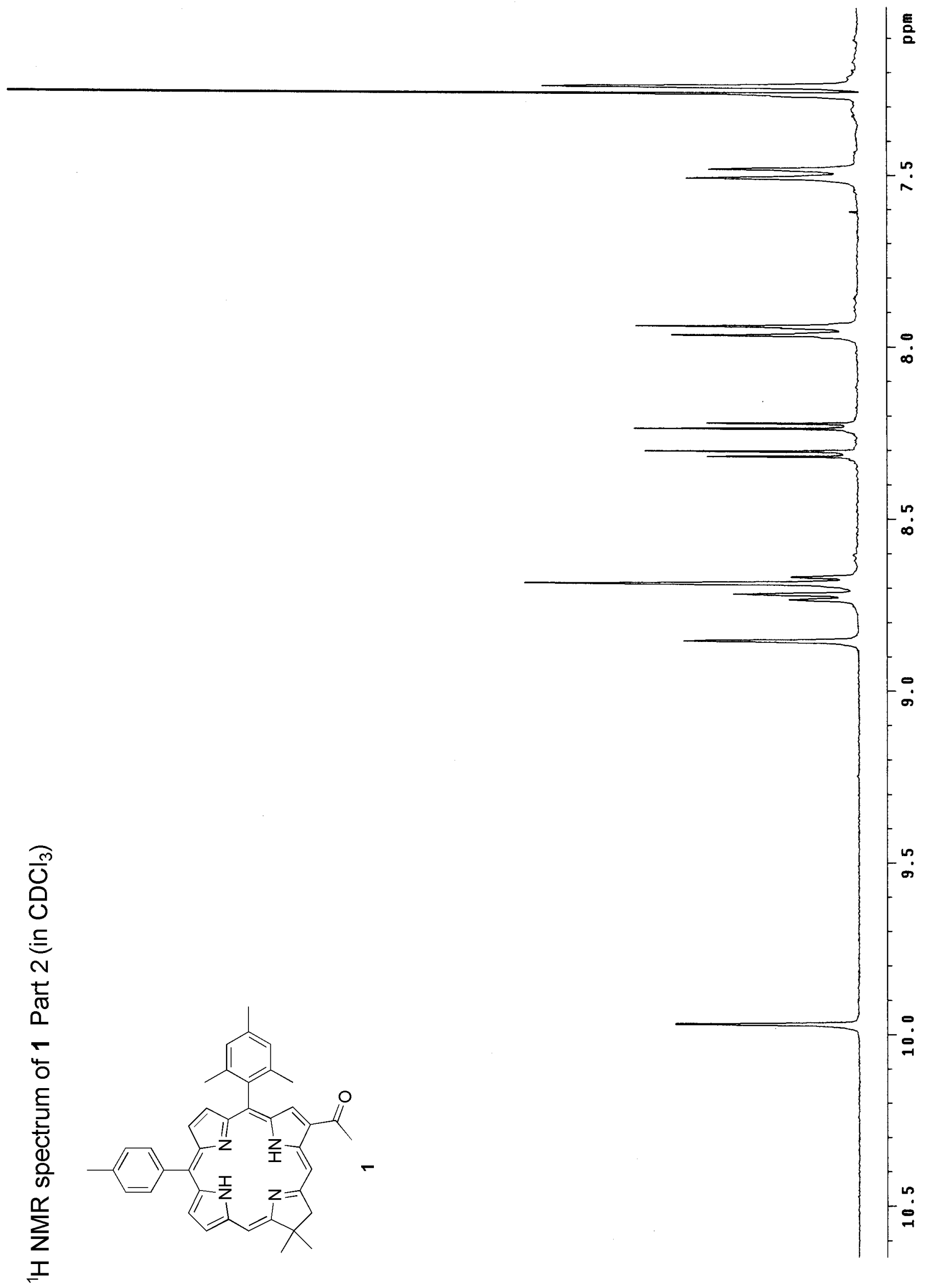



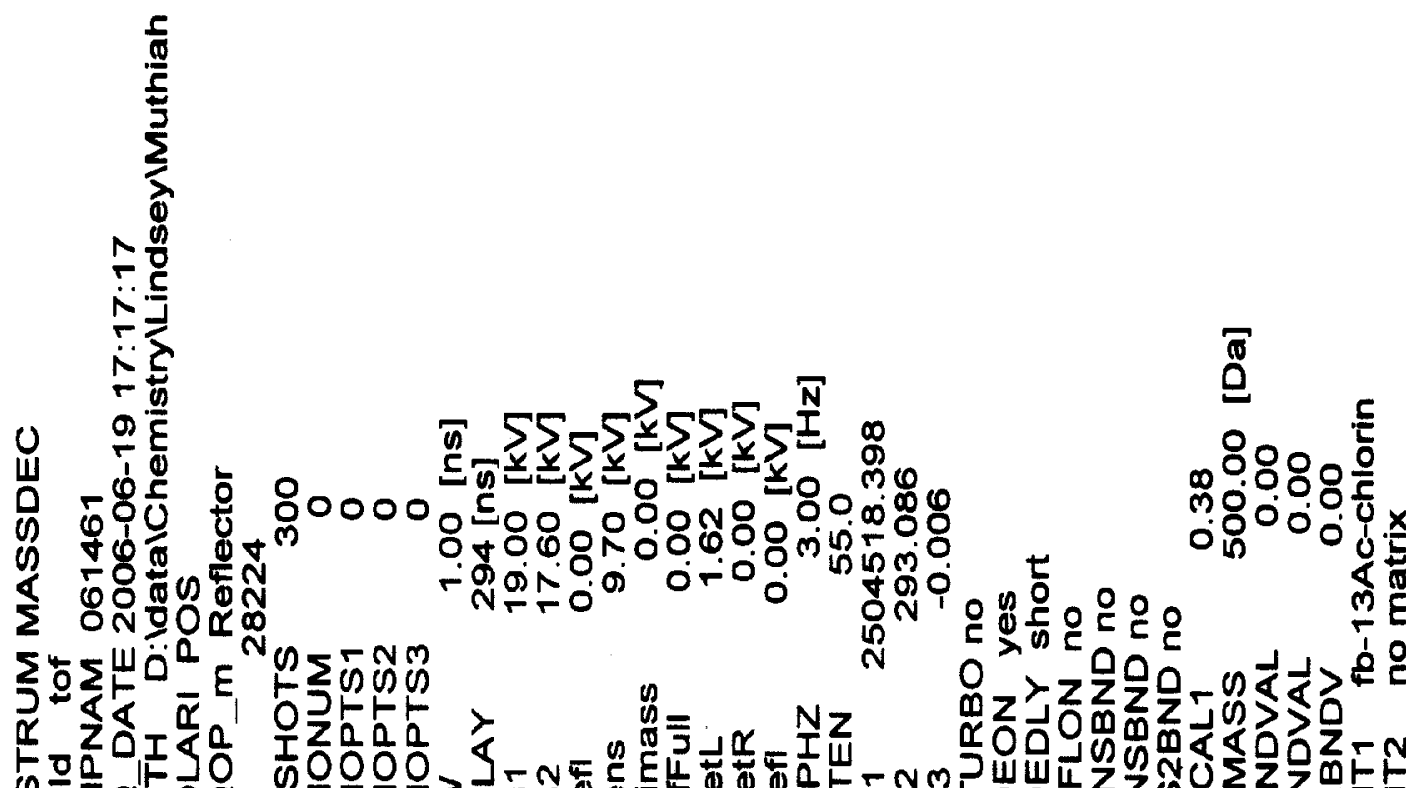

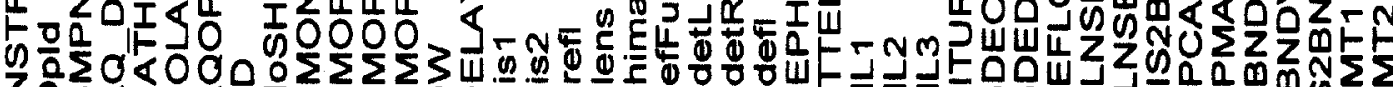

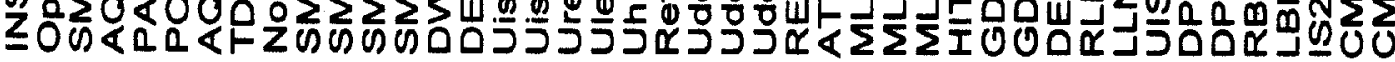

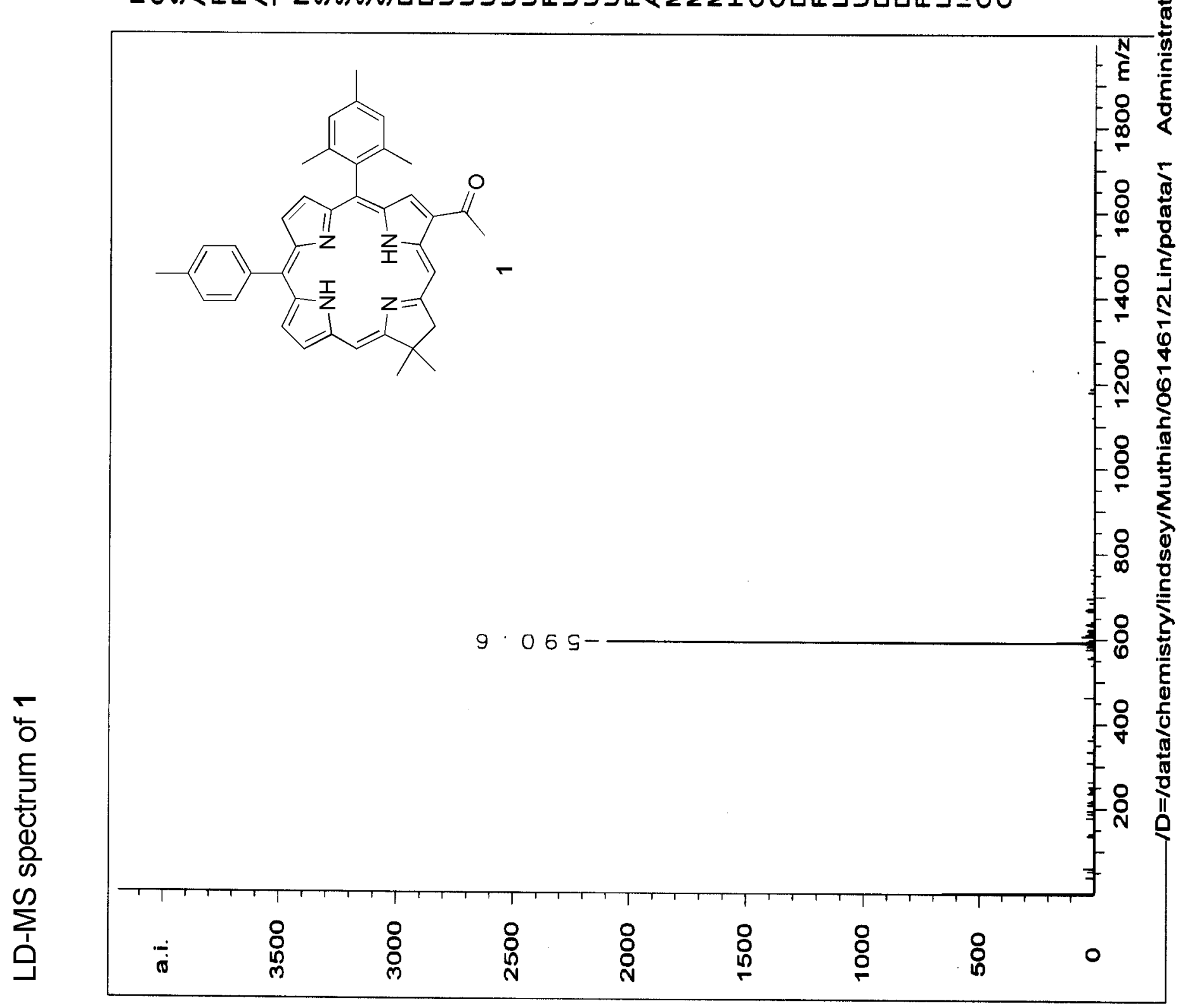




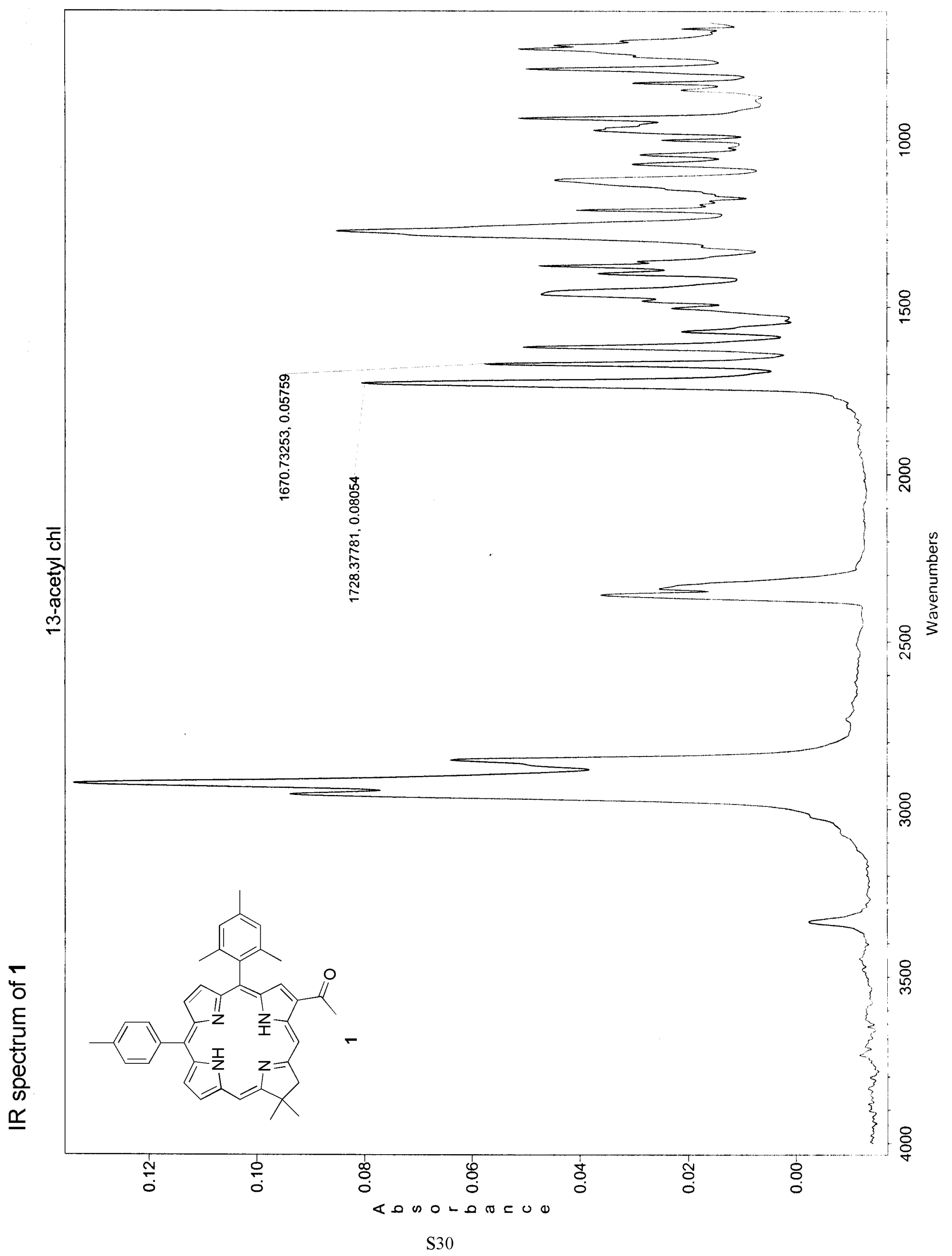




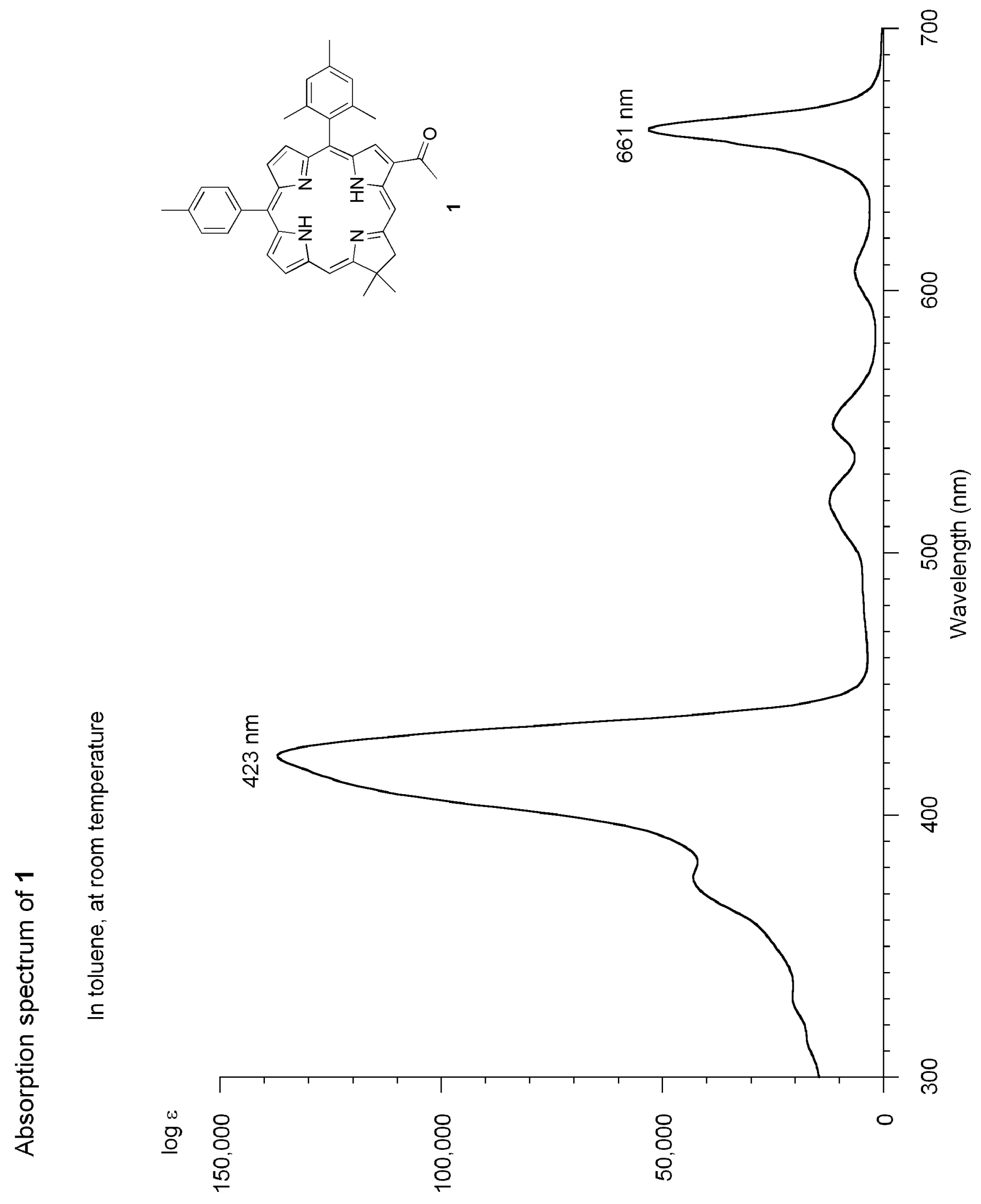




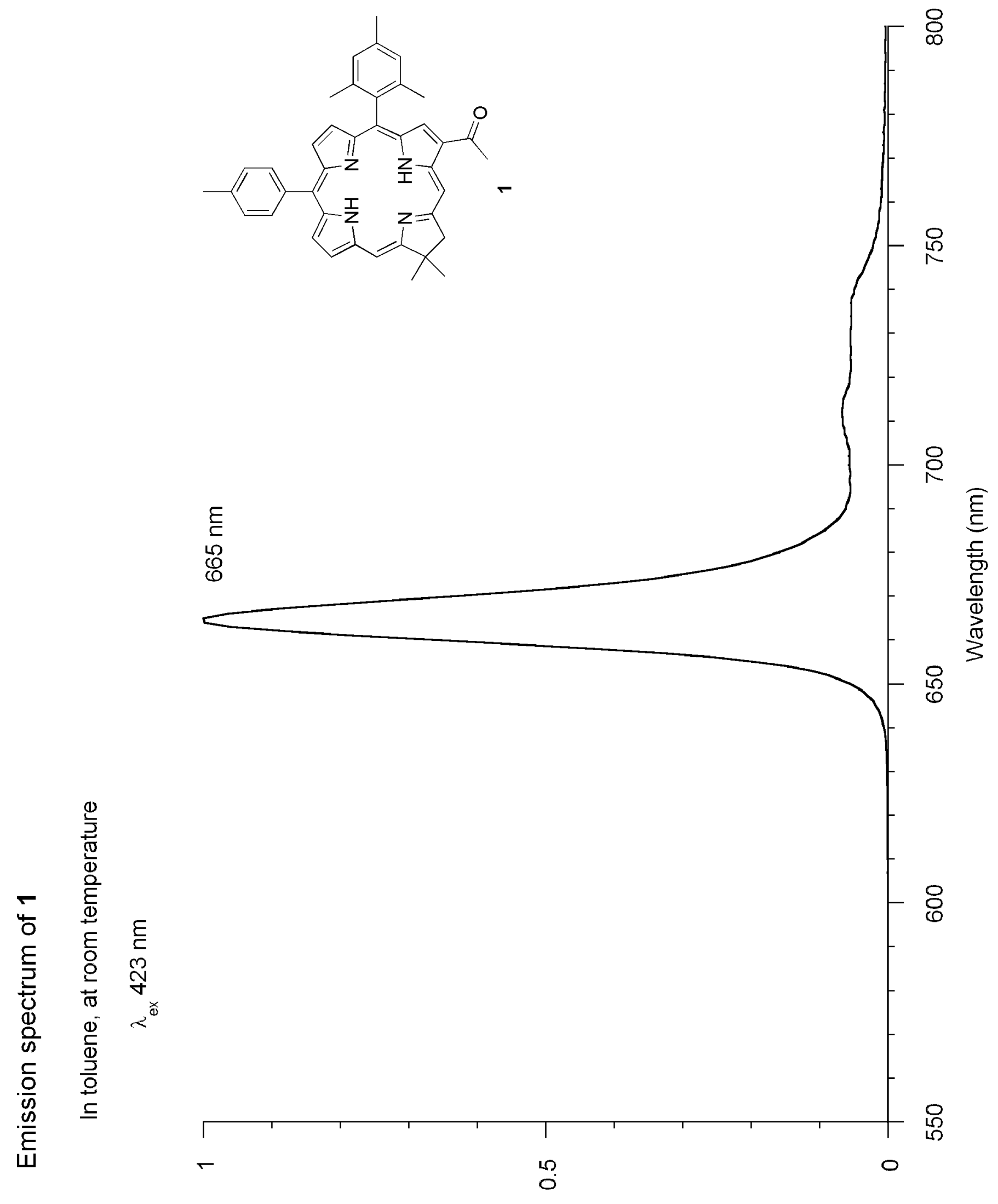

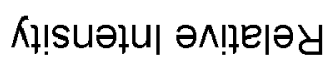




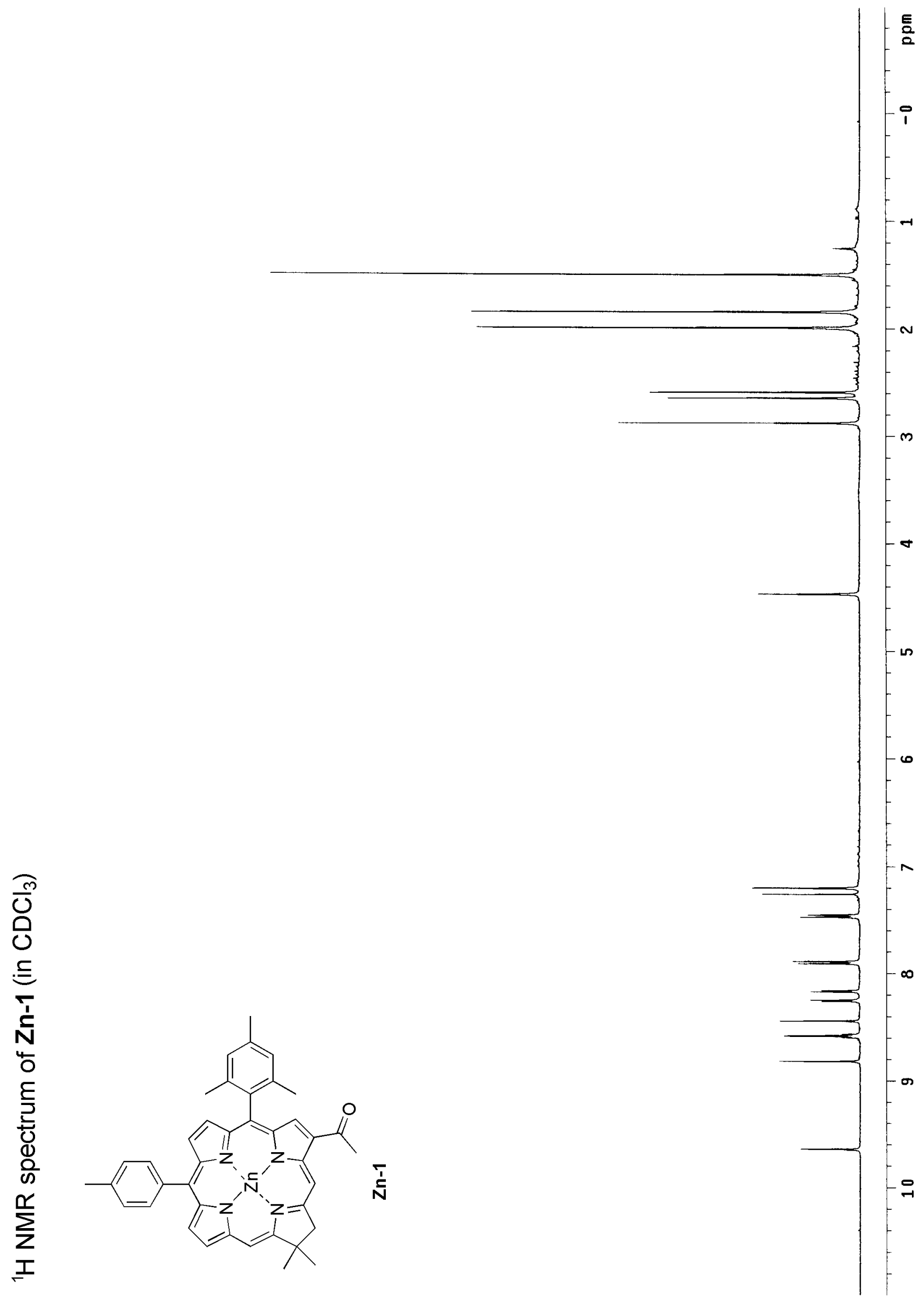




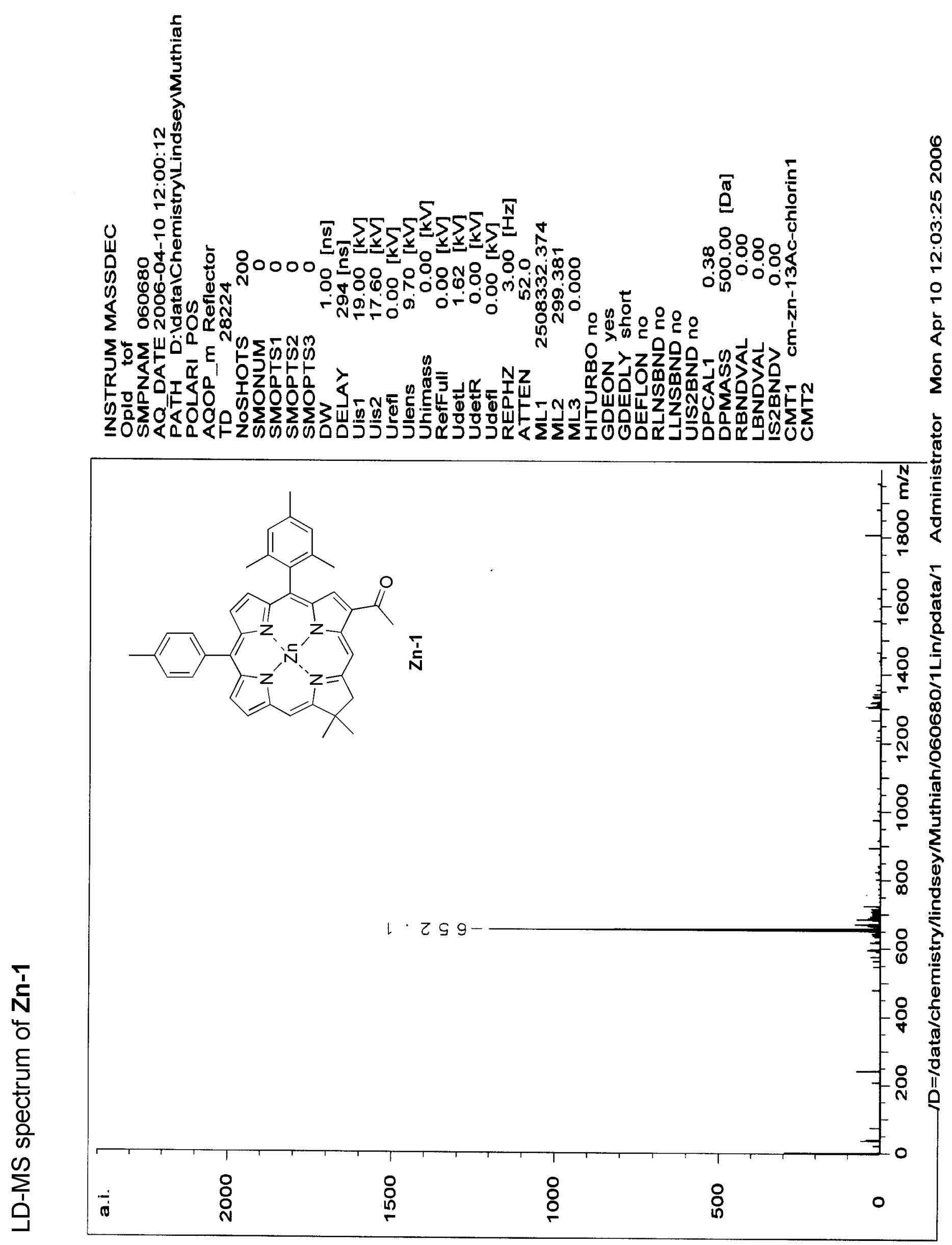




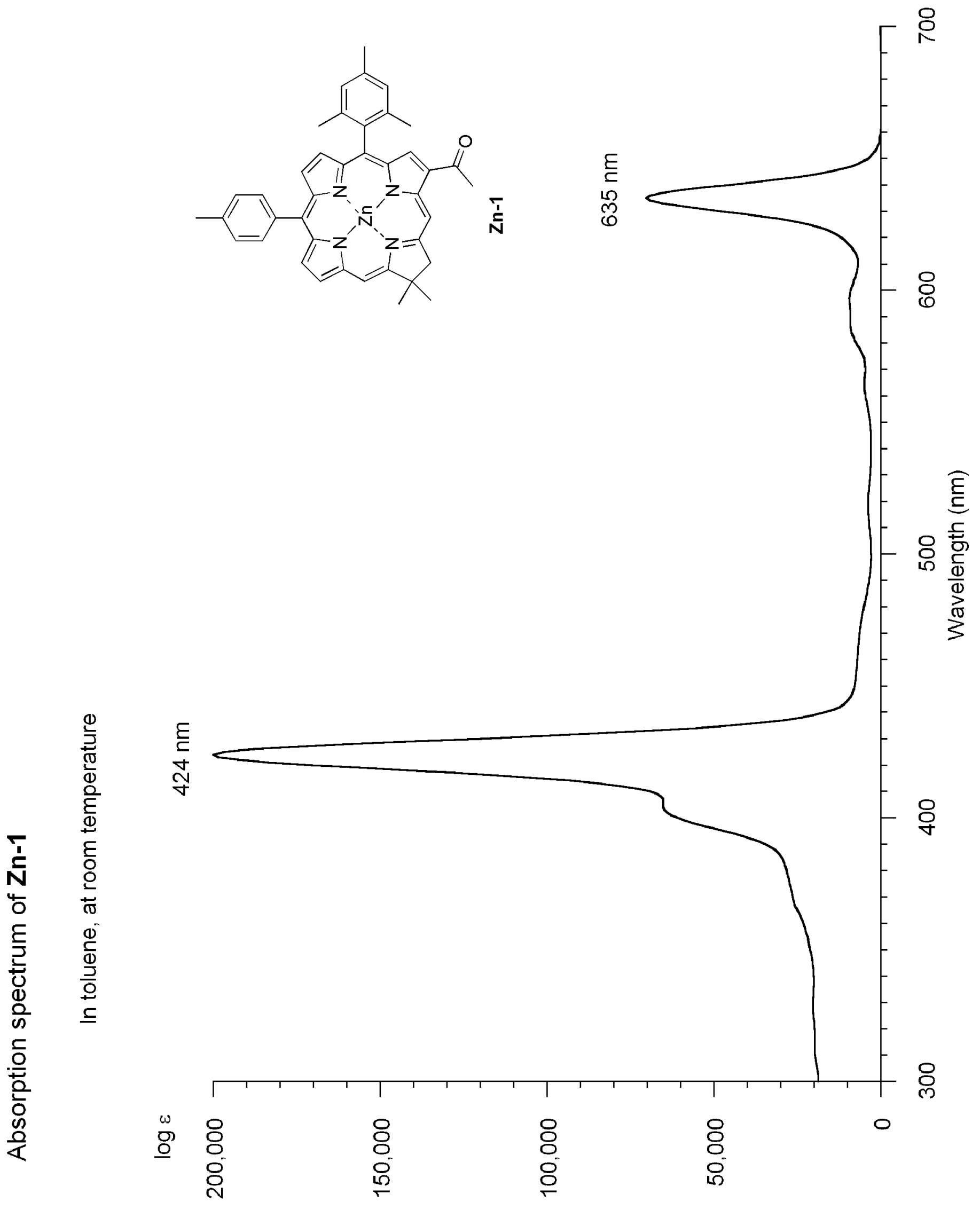




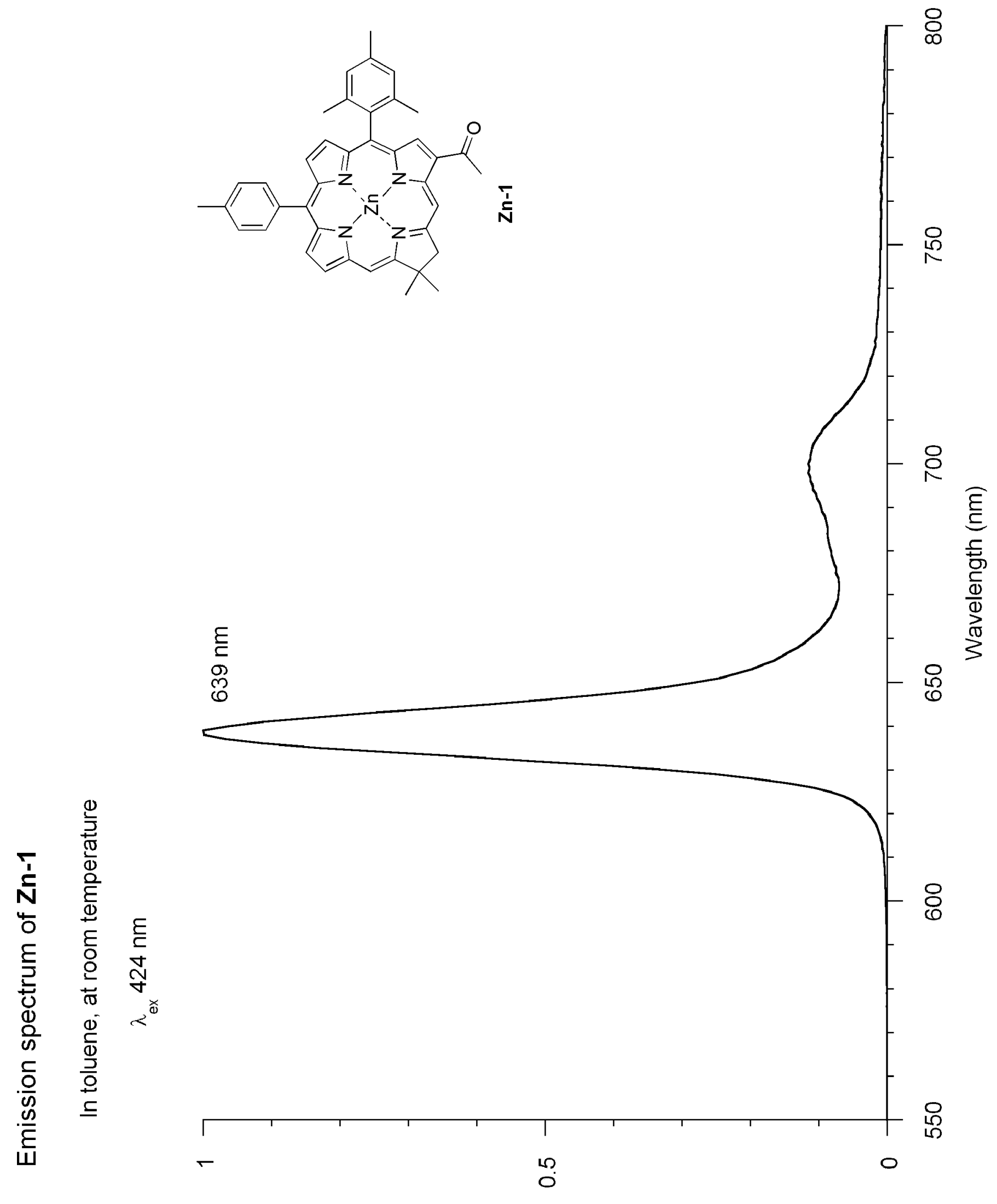

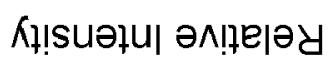




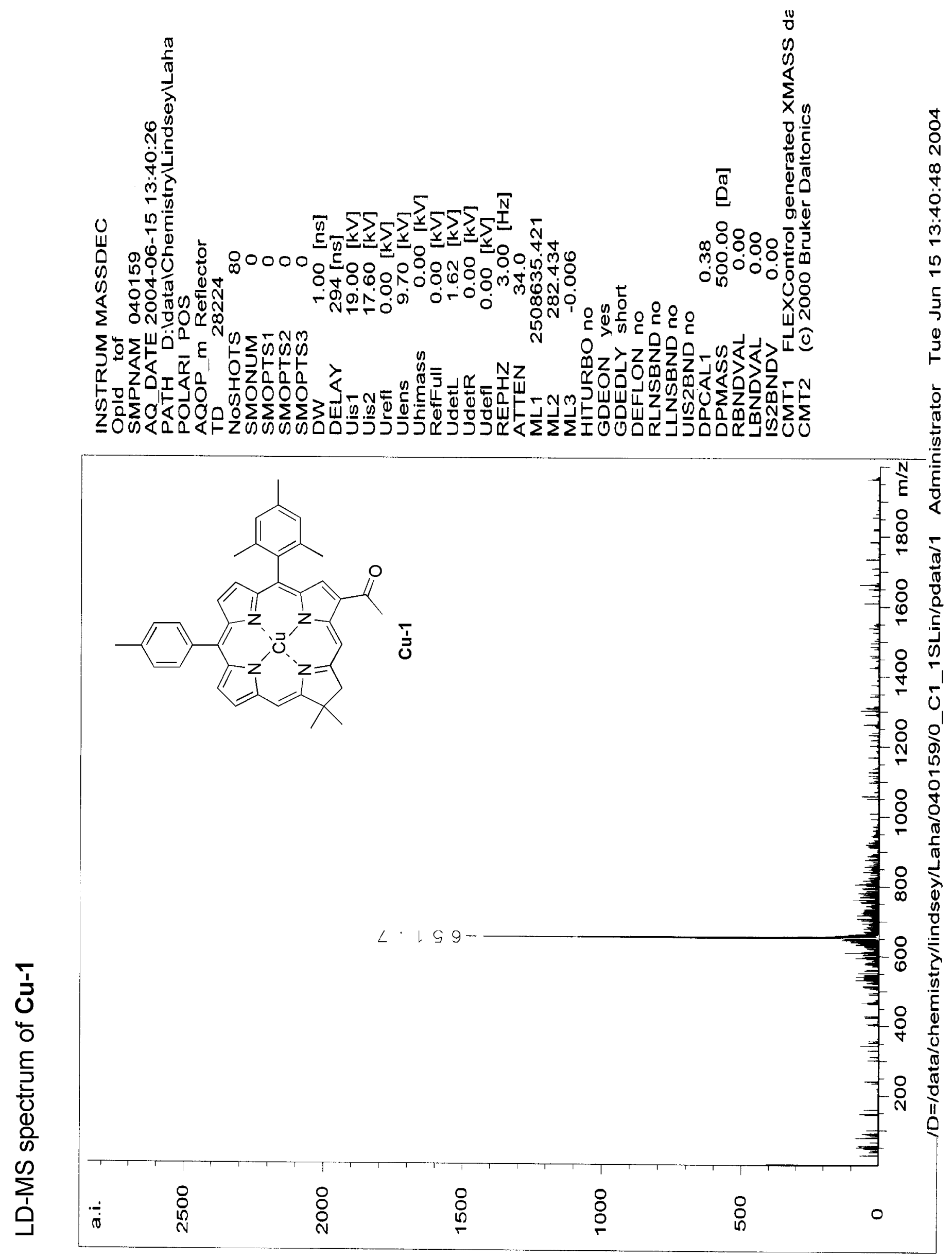



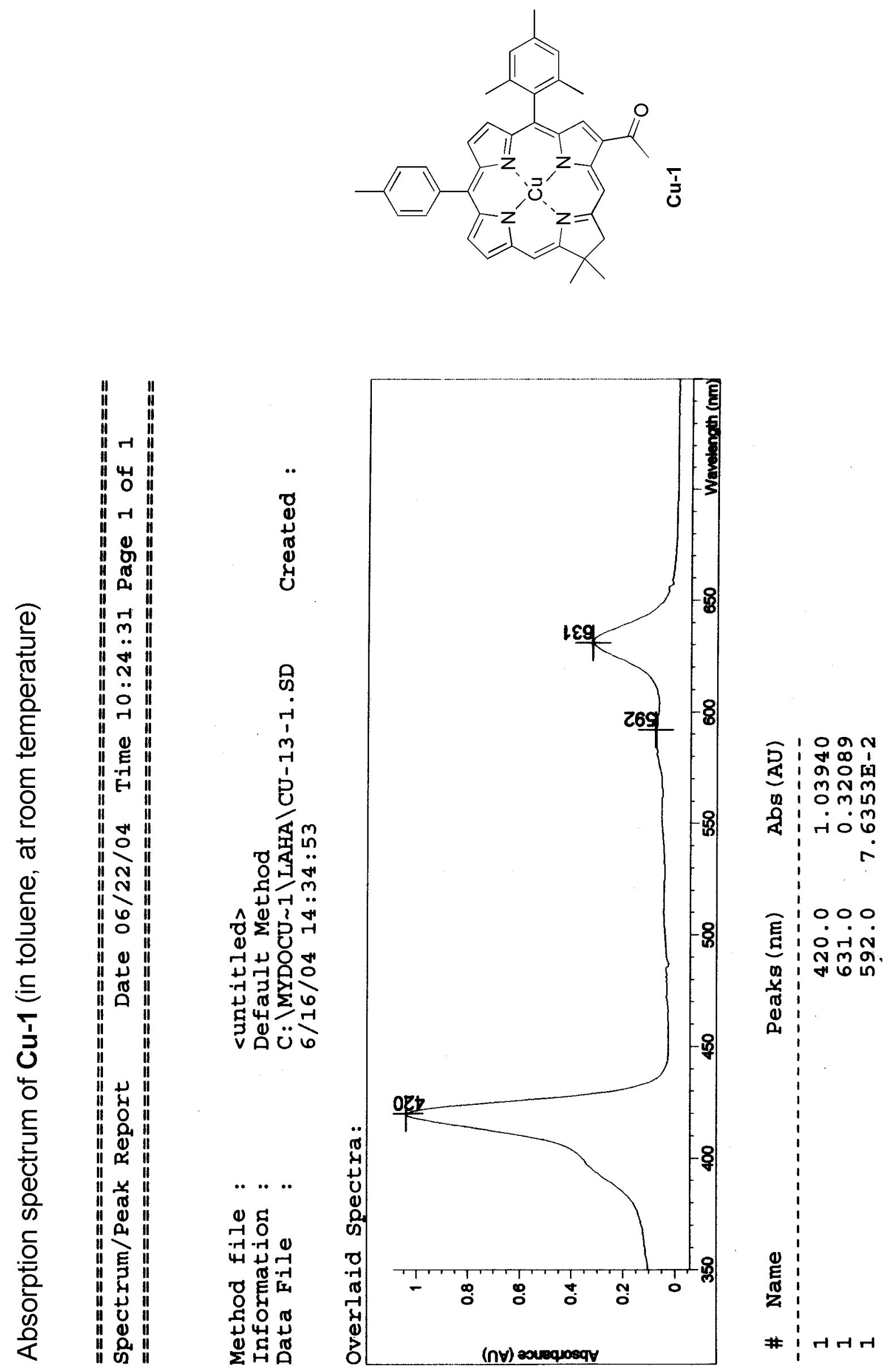


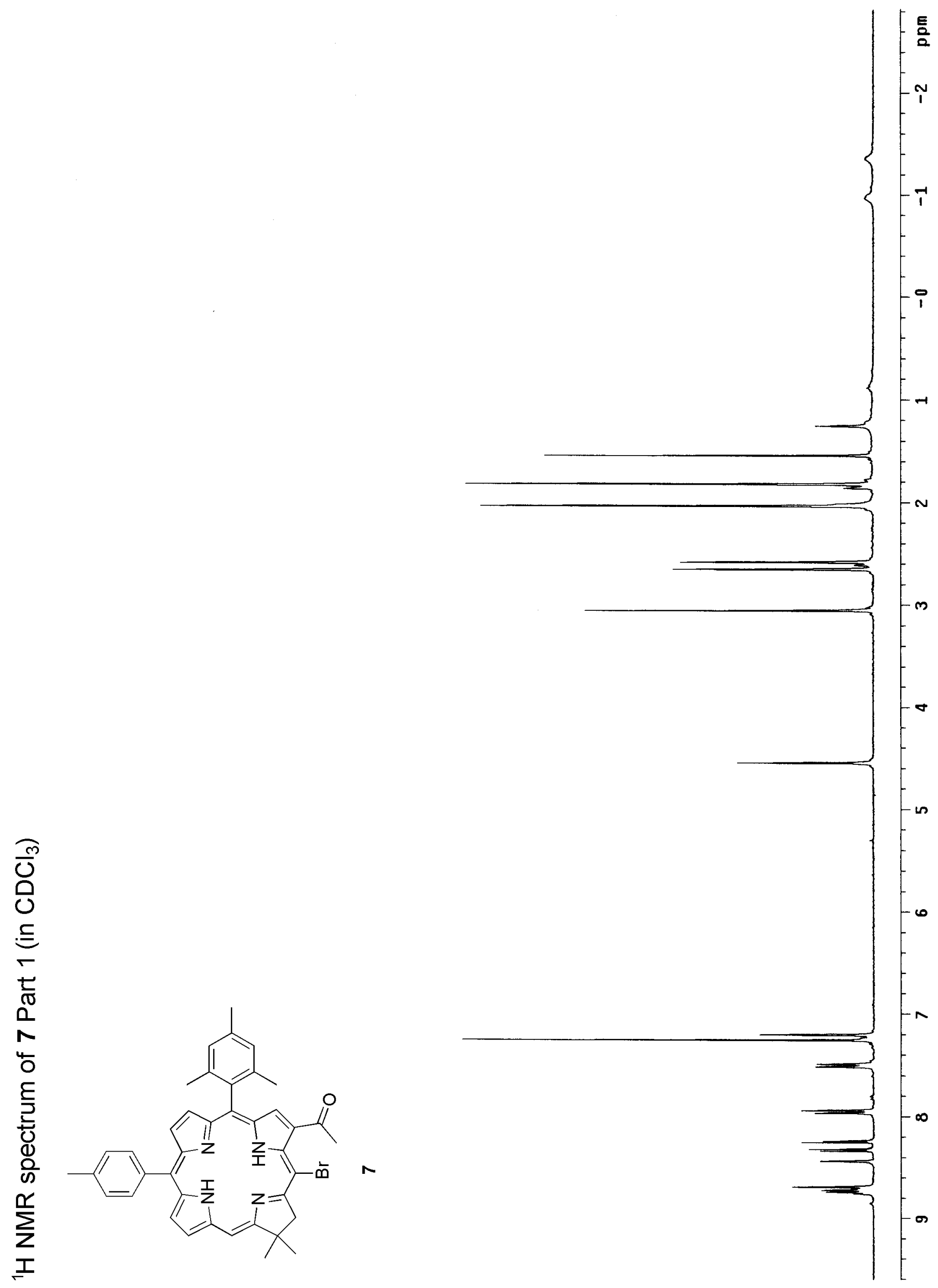



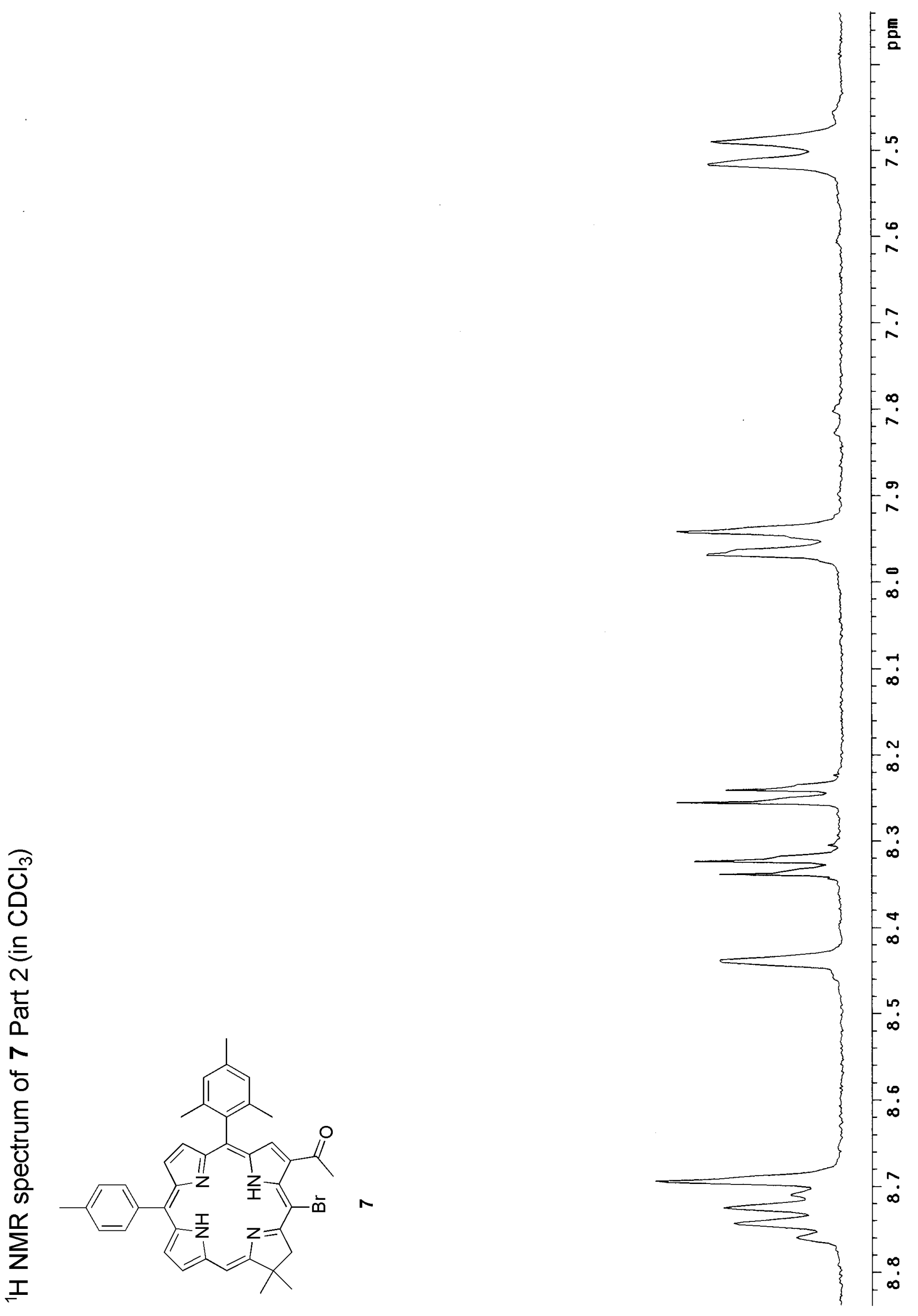


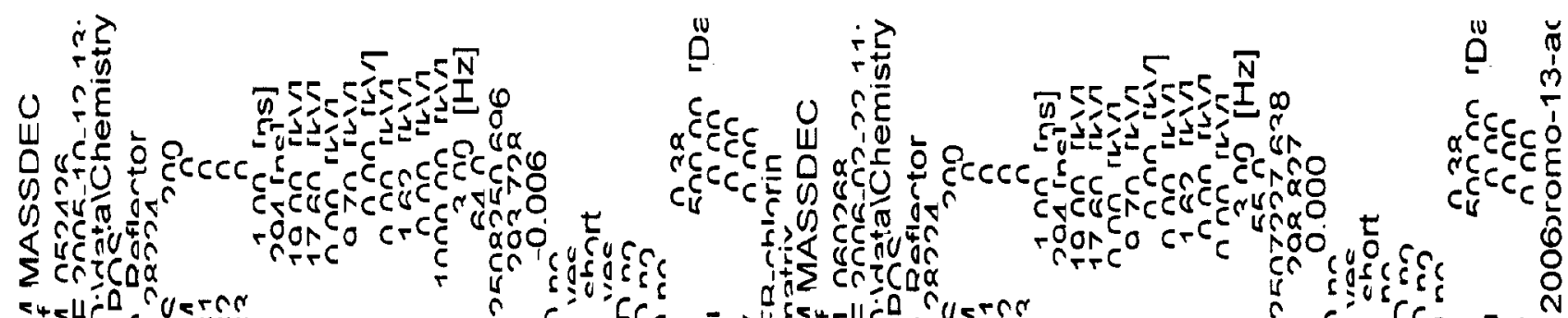

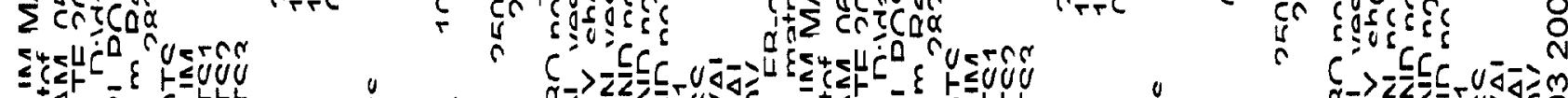

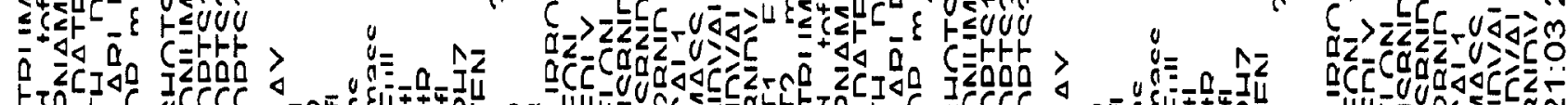

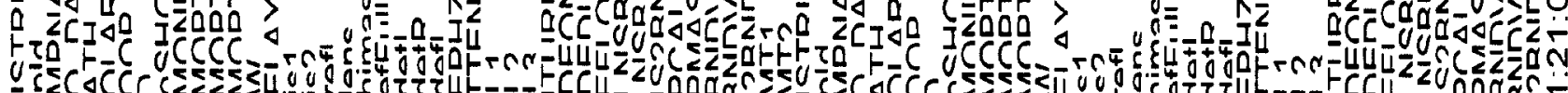

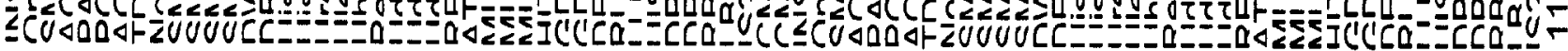

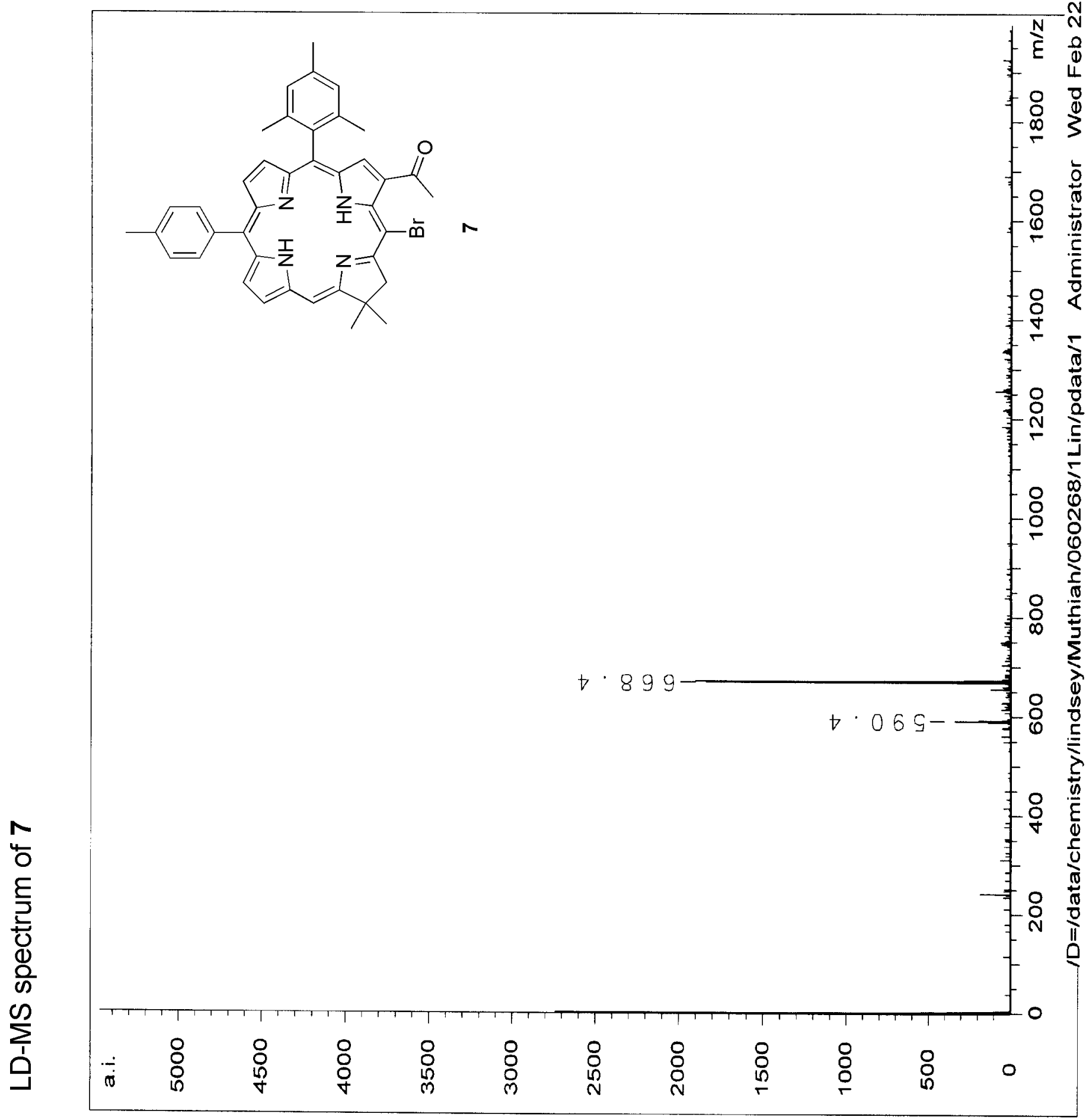



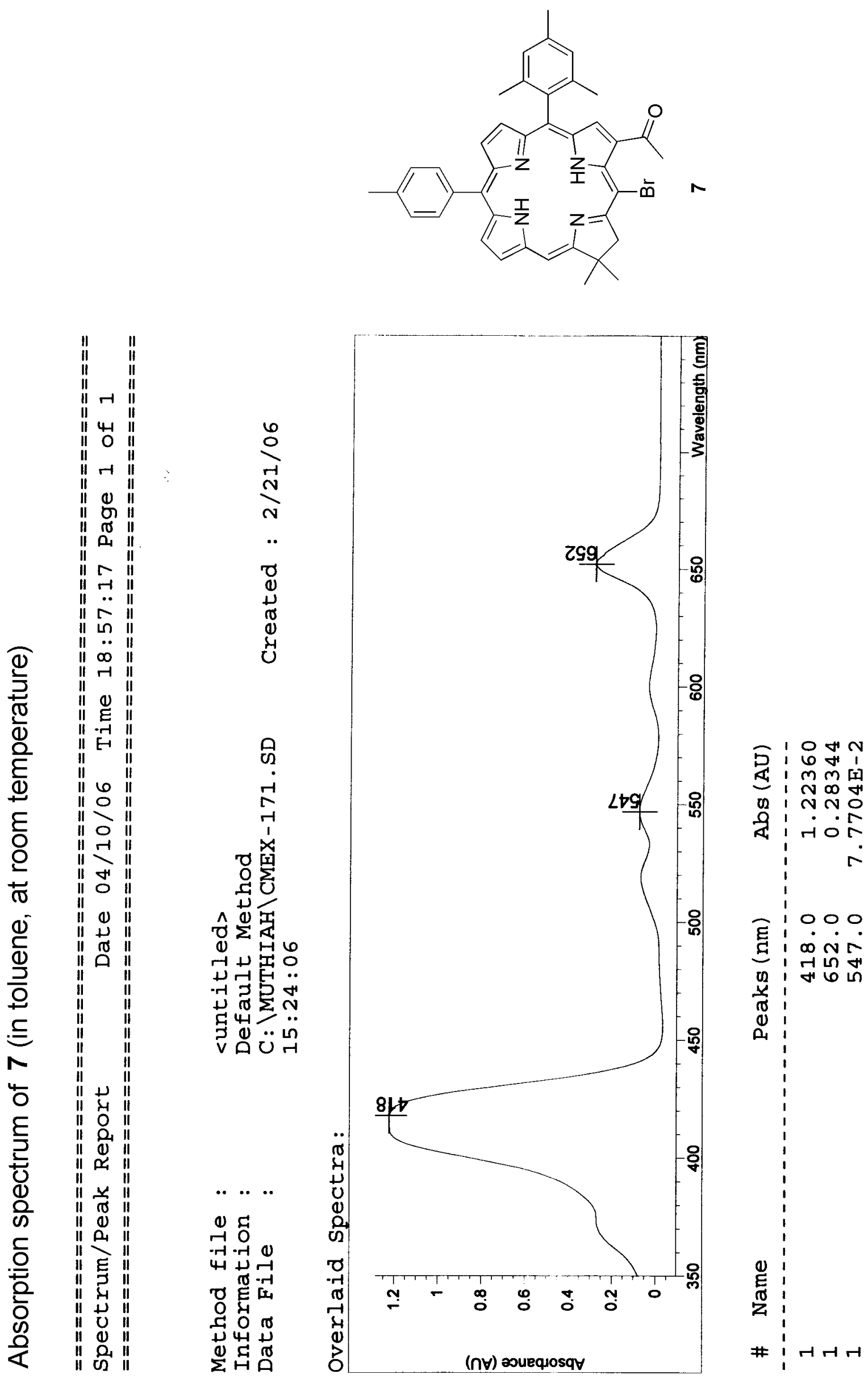


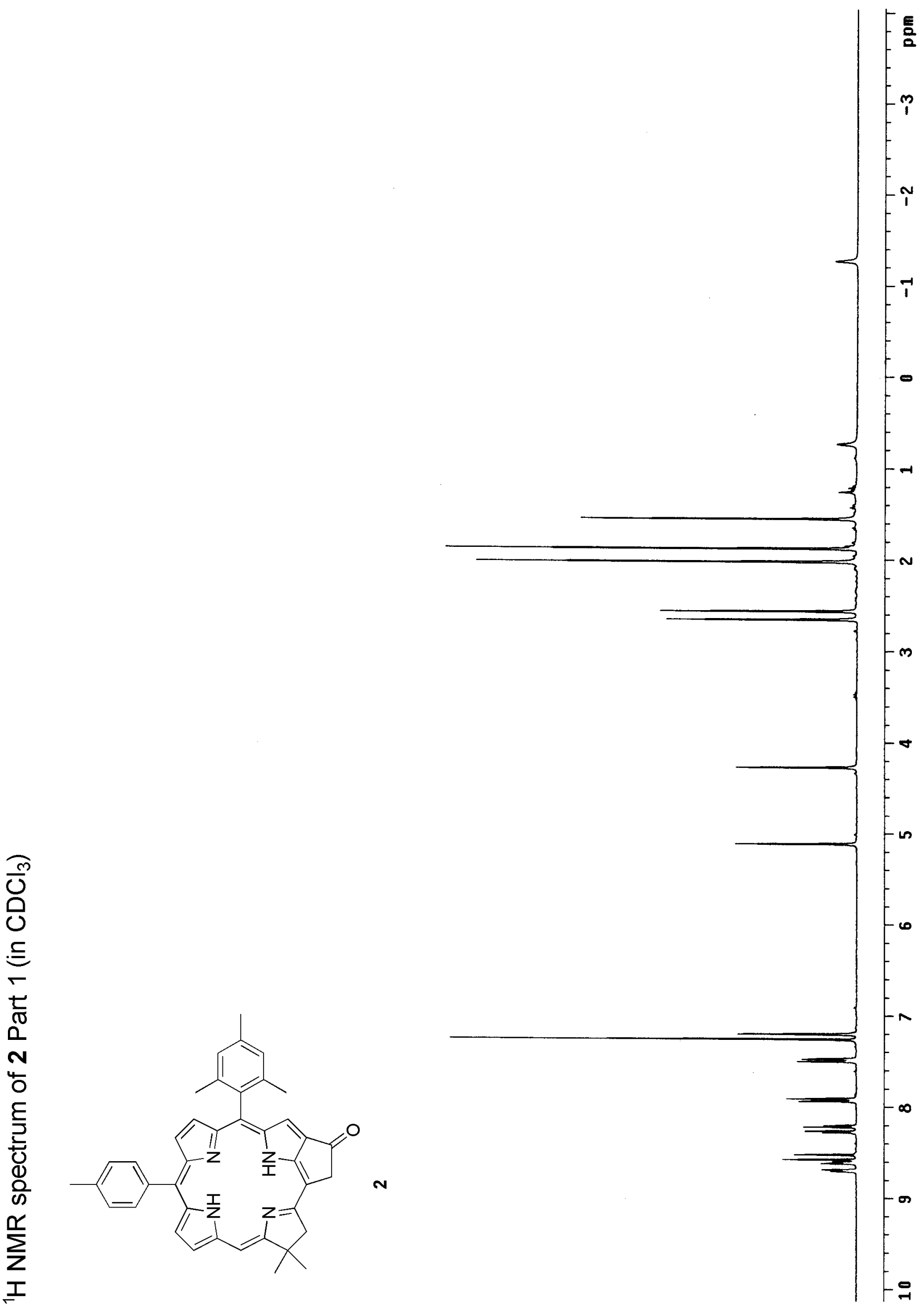




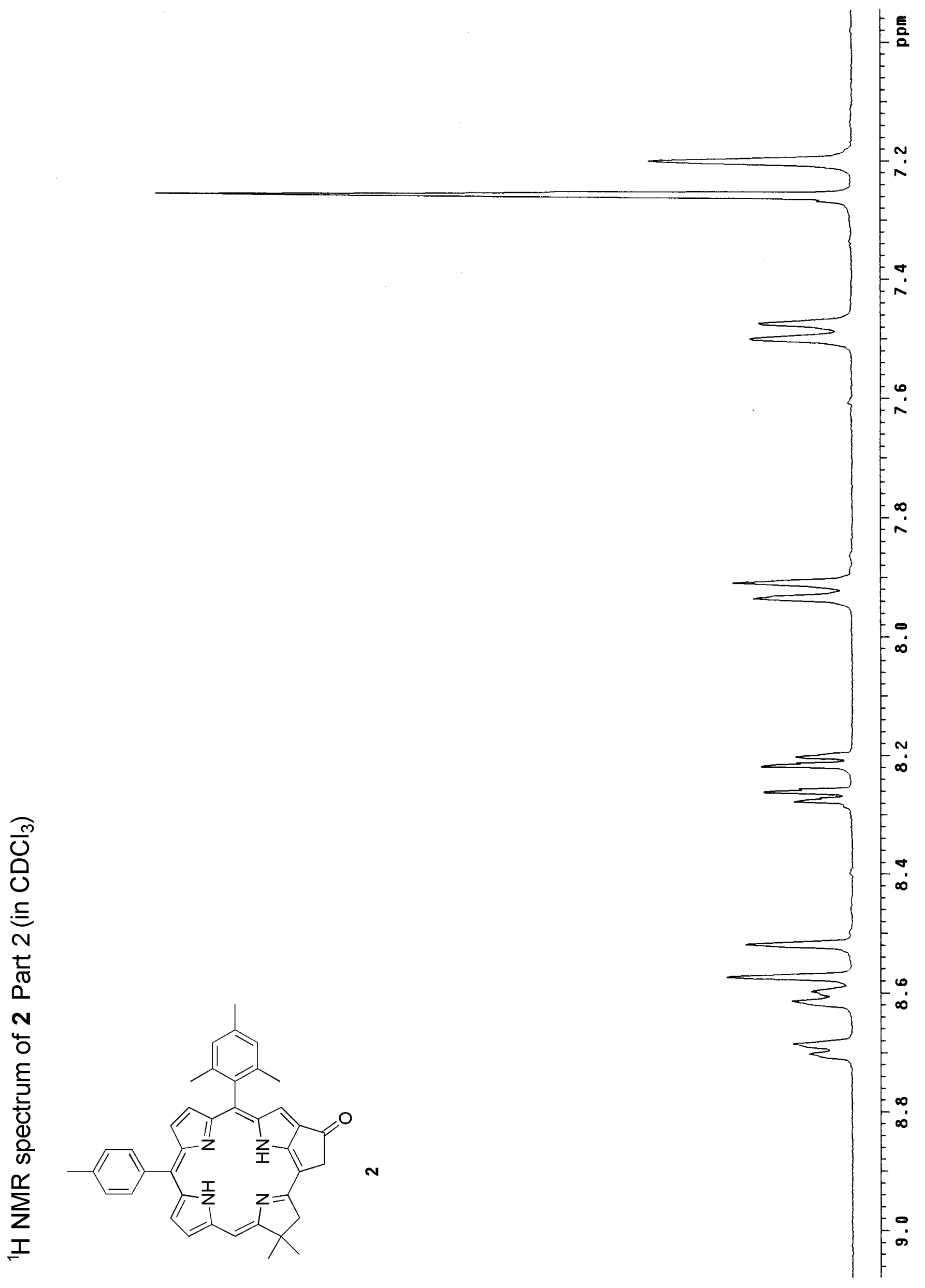




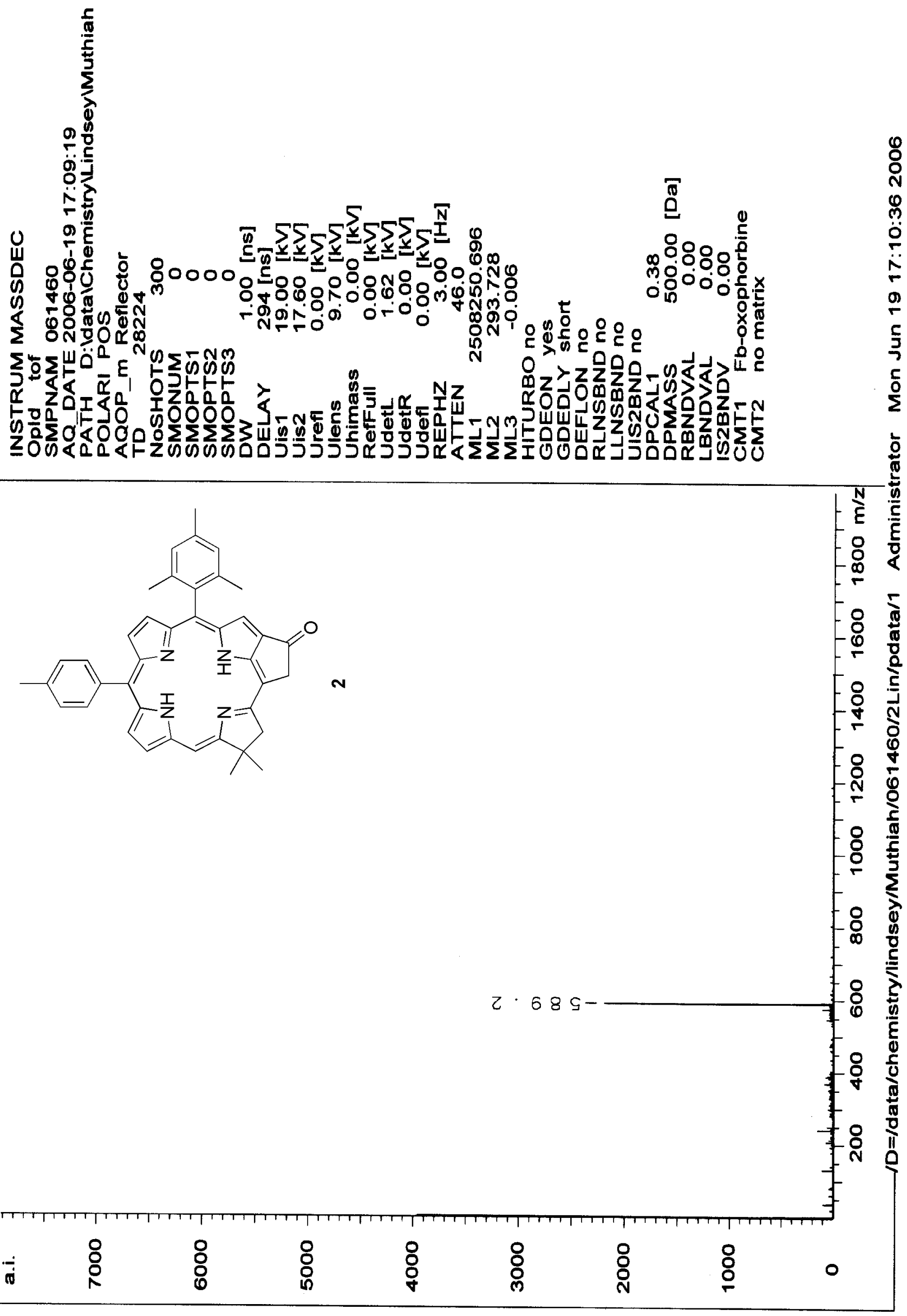




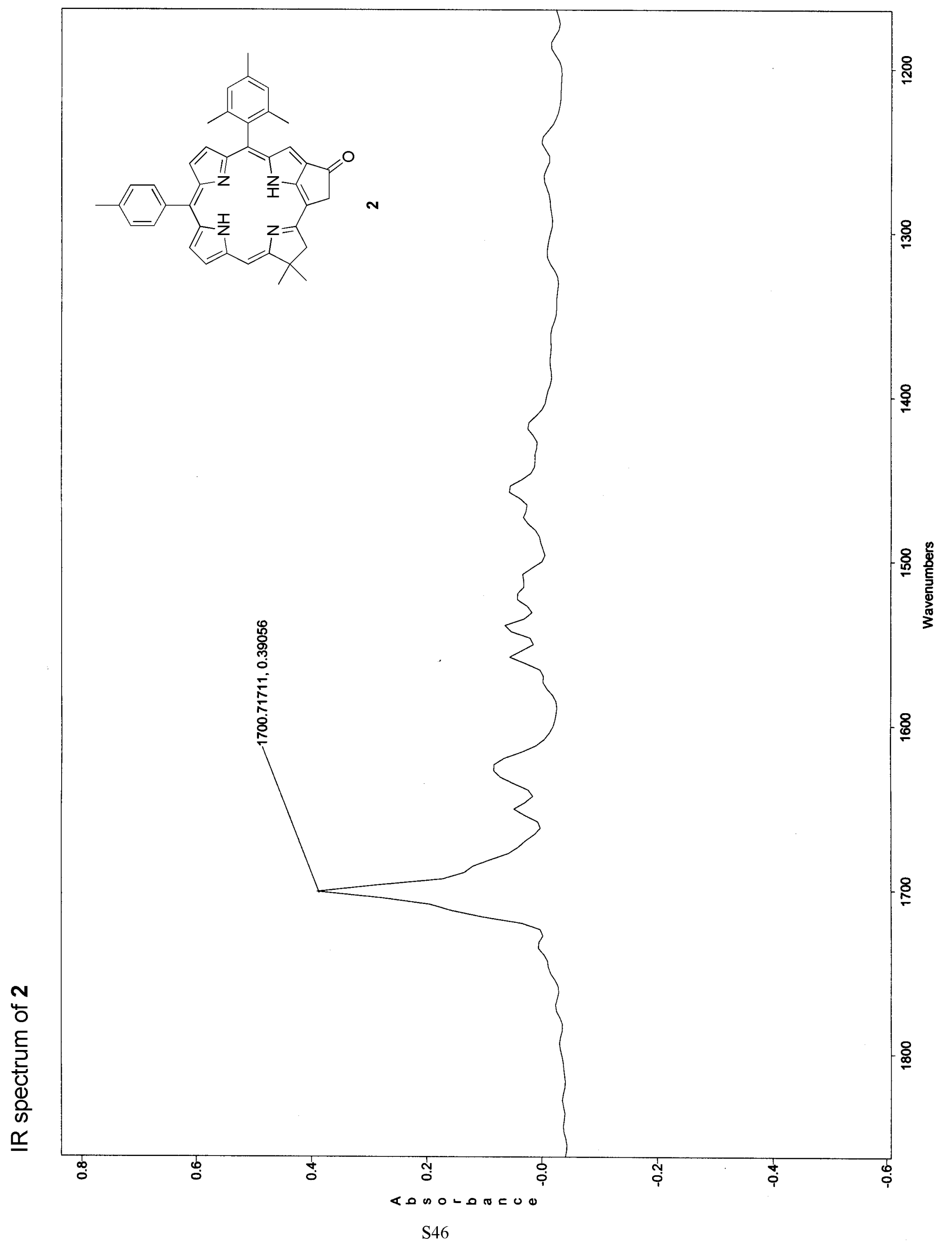




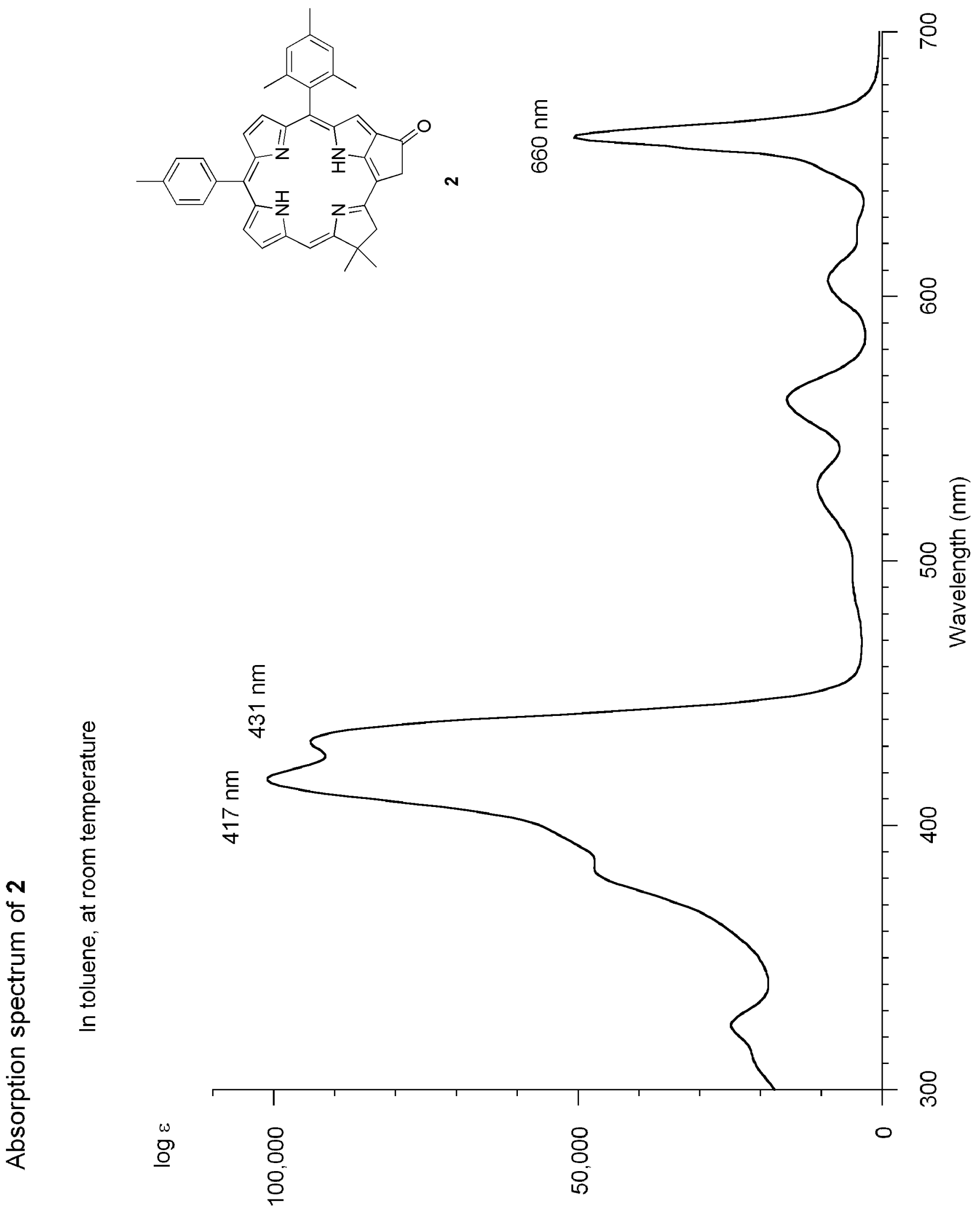




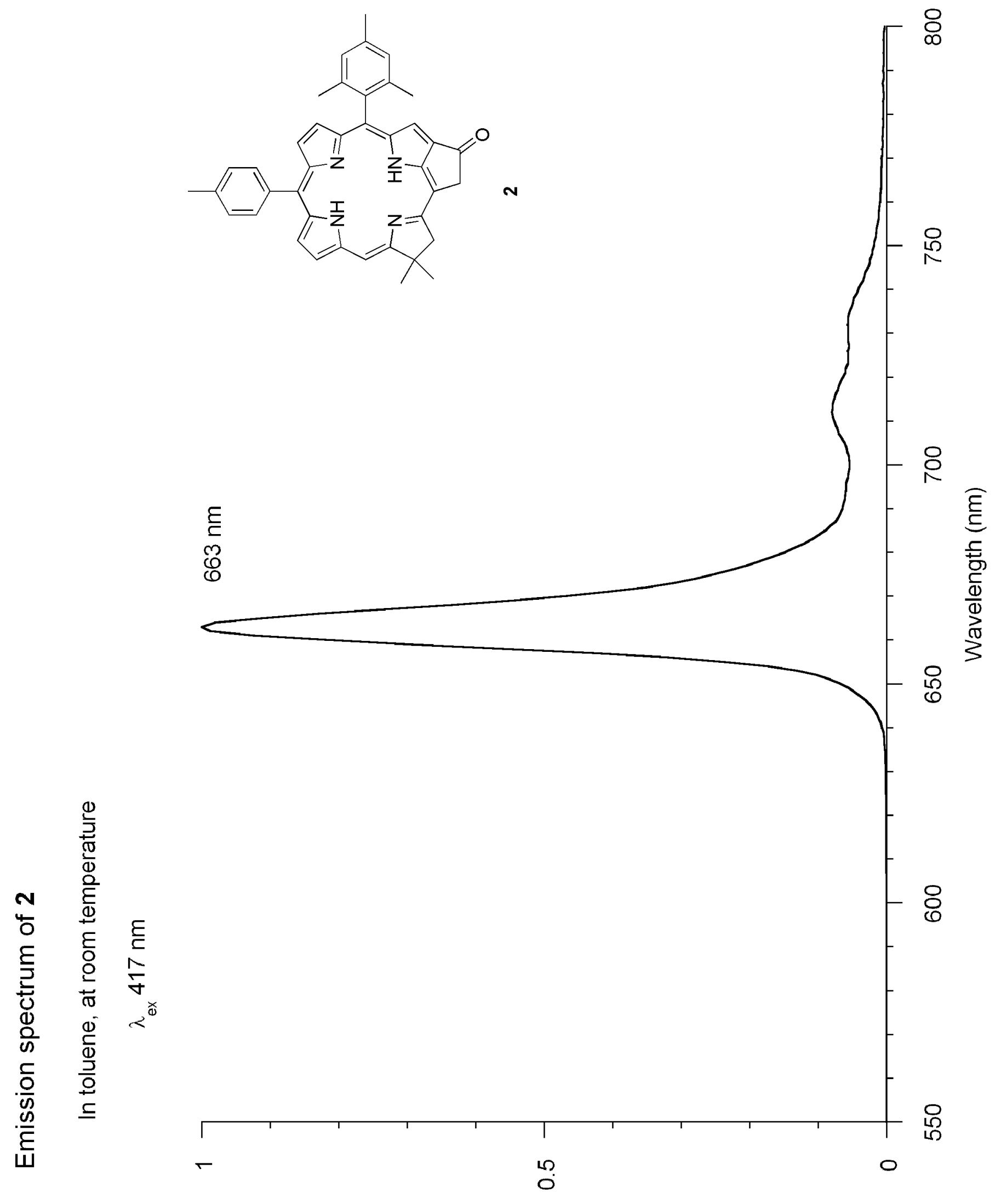

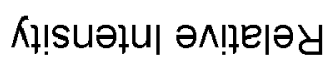




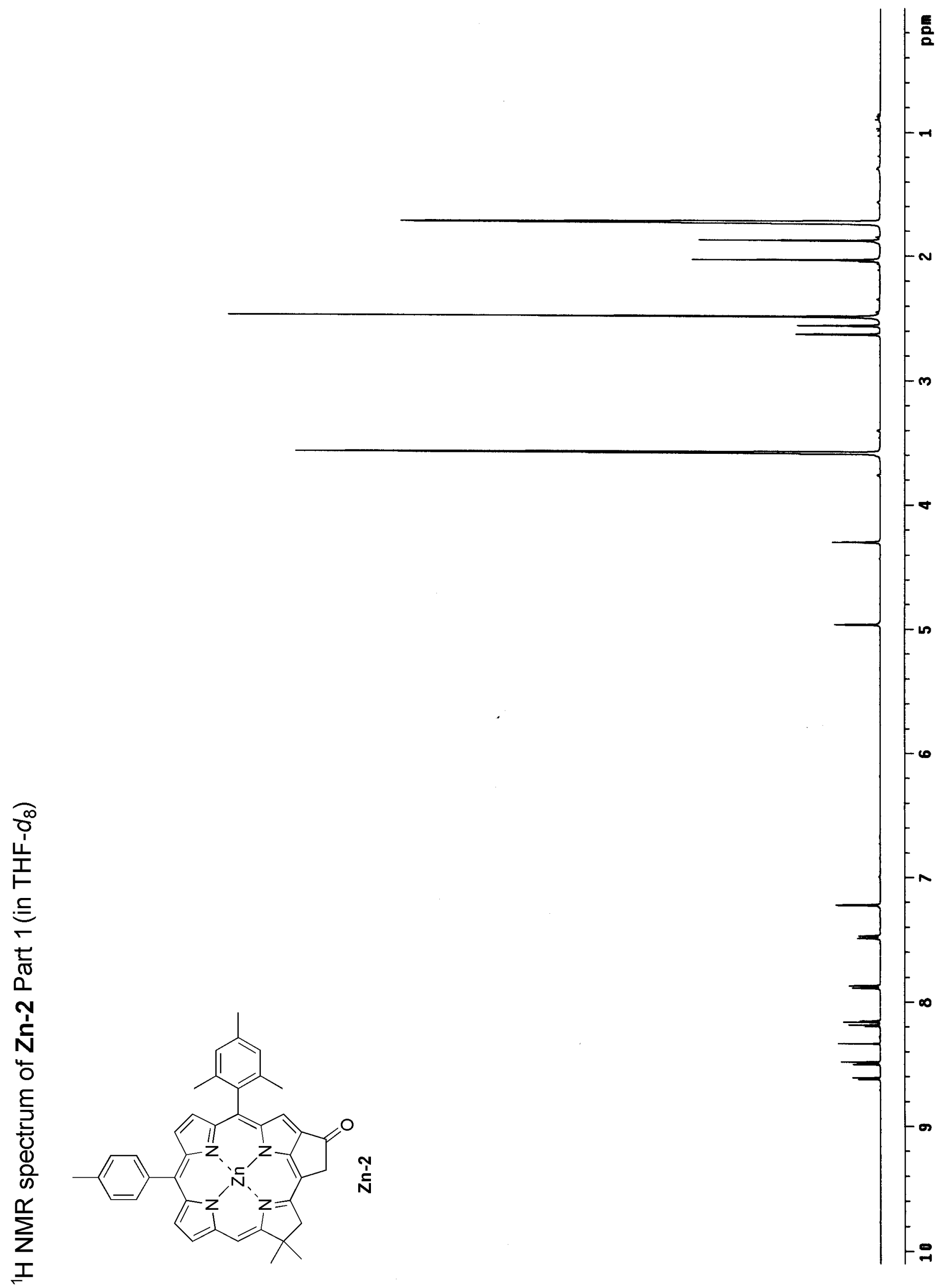




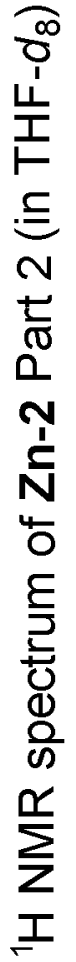

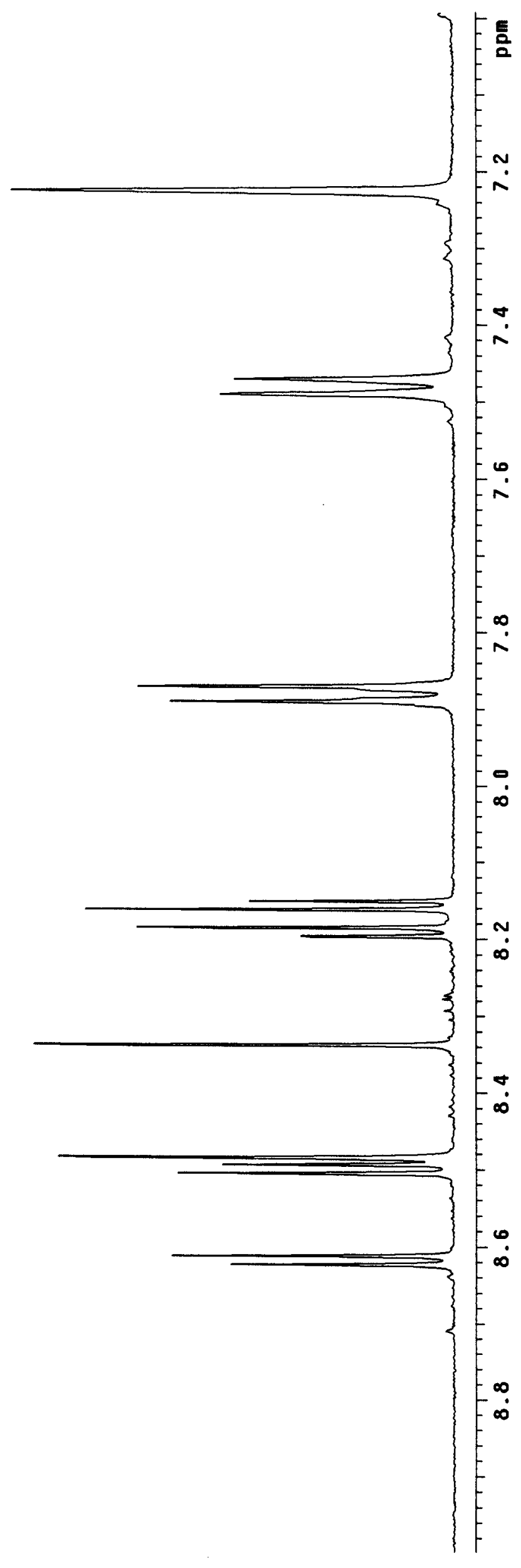




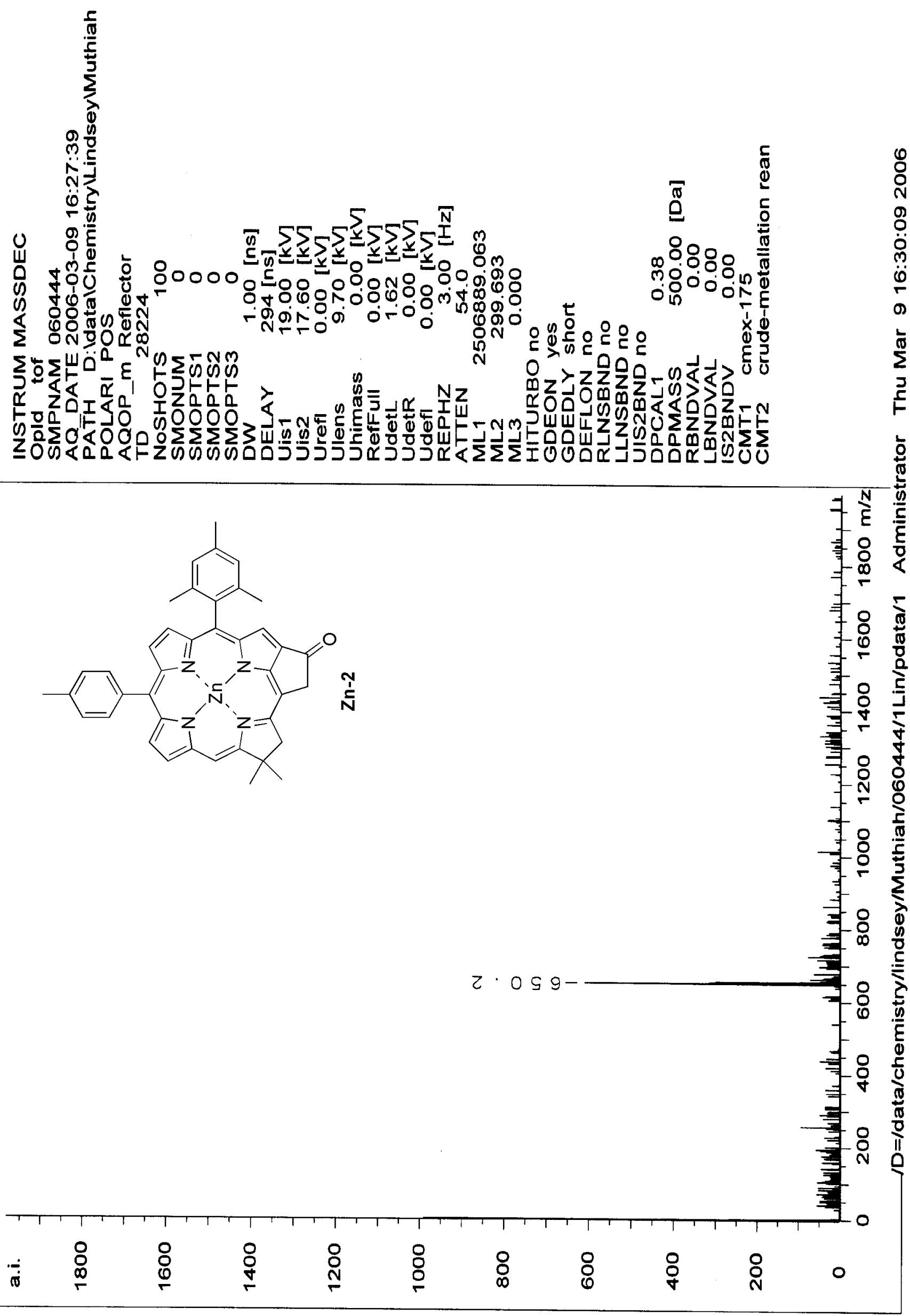




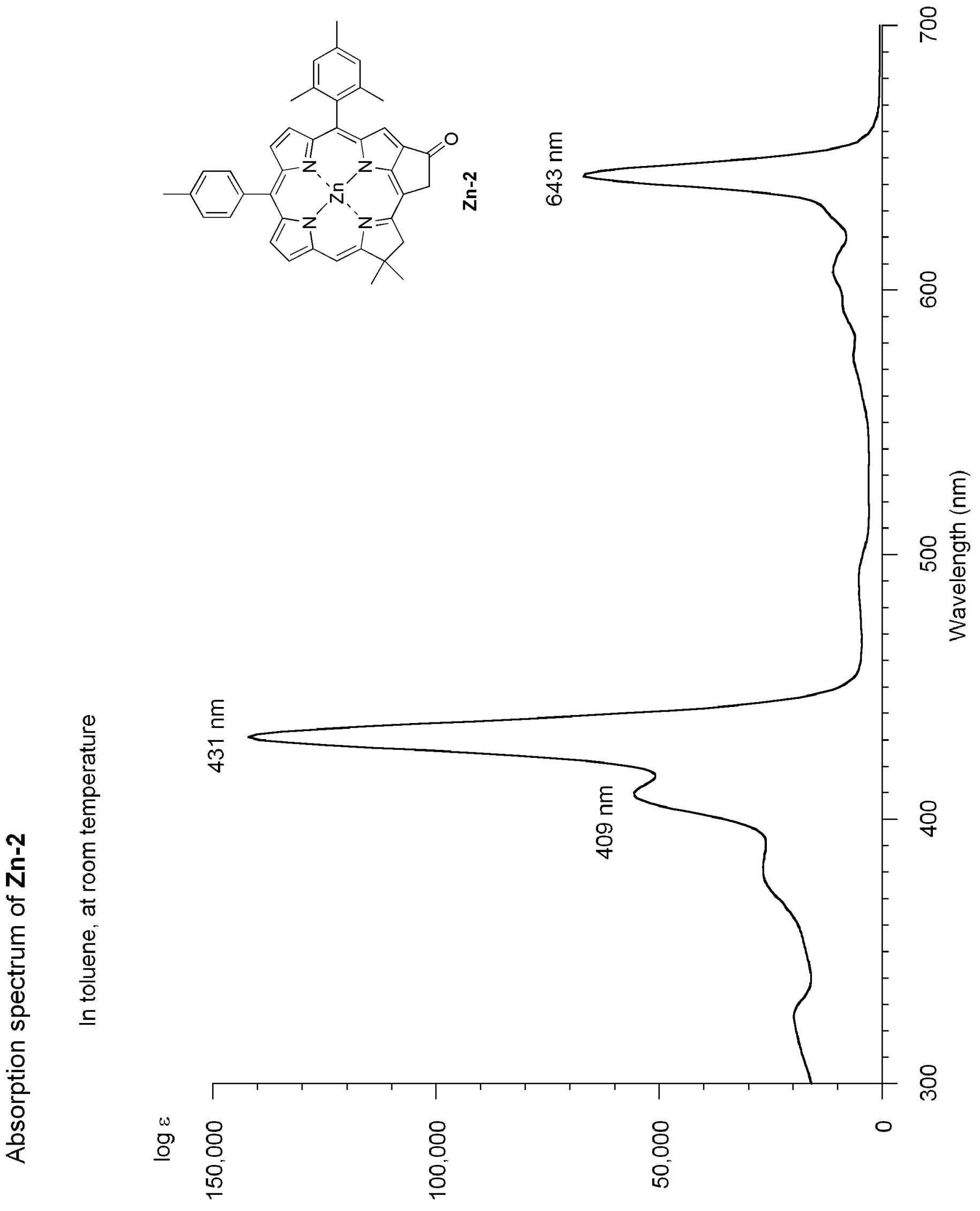




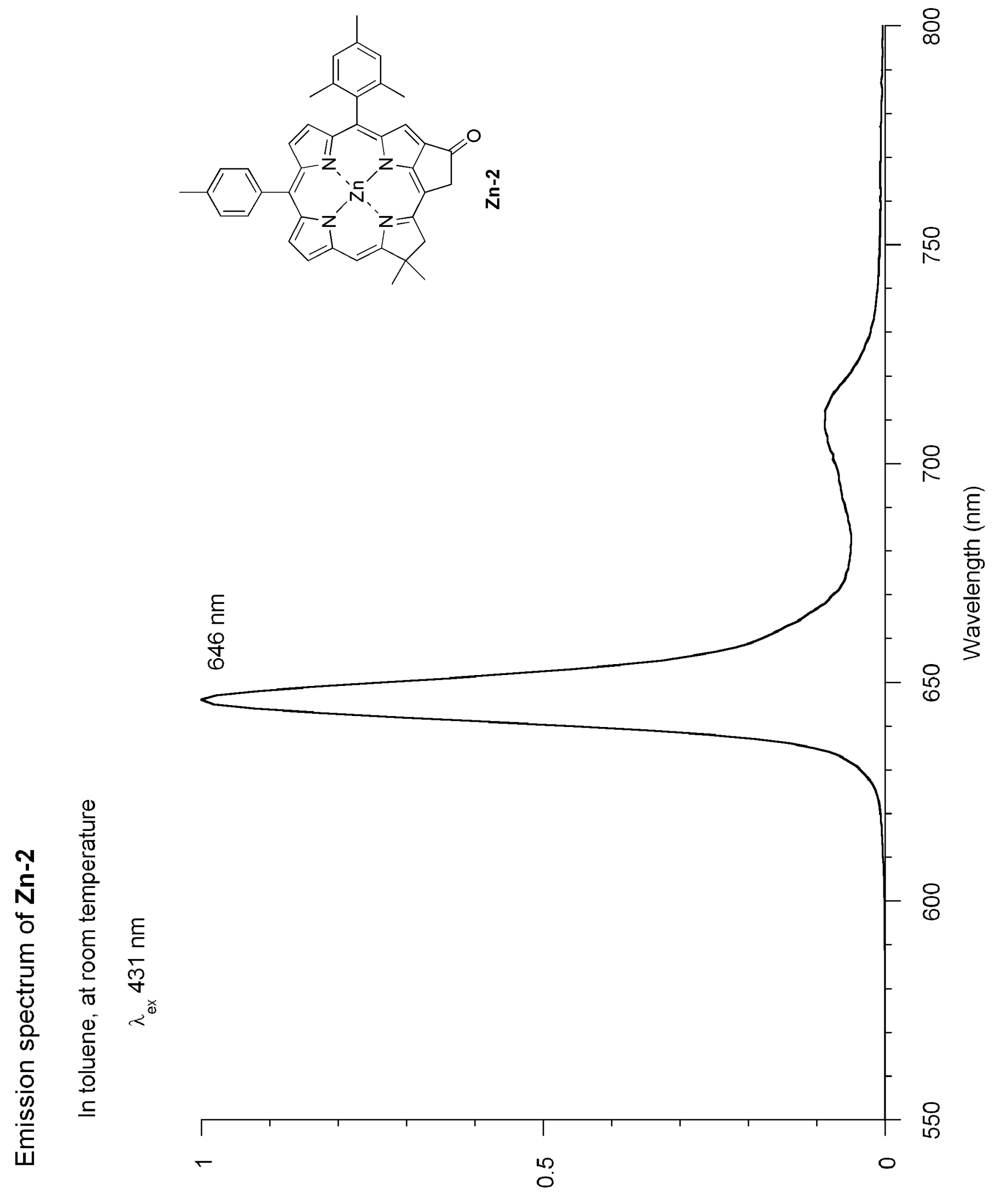

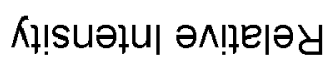

